\title{
Interhemispheric radio-astrochronological calibration of the time scales from the Andean and the Tethyan areas in the Valanginian-Hauterivian (Early Cretaceous)
}

\author{
Beatriz Aguirre-Urreta $^{\mathrm{a}, *}$, Mathieu Martinez ${ }^{\mathrm{b}, \mathrm{c}}$, Mark Schmitz ${ }^{\mathrm{d}}$, Marina Lescano ${ }^{\mathrm{a}}$, Julieta Omarini ${ }^{\mathrm{e}}$, \\ Maisa Tunik ${ }^{\mathrm{e}}$, Henning Kuhnert ${ }^{\mathrm{b}}$, Andrea Concheyro ${ }^{\text {a }}$, Peter F. Rawson ${ }^{\text {f,g }}$, Victor A. Ramos ${ }^{\mathrm{a}}$, \\ Stéphane Reboulet ${ }^{\mathrm{h}}$, Nicolas Noclin ${ }^{\mathrm{h}}$, Thomas Frederichs ${ }^{\mathrm{b}}$, Anna-Leah Nickl ${ }^{\mathrm{b}}$, Heiko Pälike ${ }^{\mathrm{b}}$ \\ a Instituto de Estudios Andinos Don Pablo Groeber, CONICET \& Universidad de Buenos Aires, 1428 Buenos Aires, Argentina \\ ${ }^{\mathrm{b}}$ MARUM - Center for Marine Environmental Sciences, Universität Bremen, 28359 Bremen, Germany \\ c Univ Rennes, CNRS, Géosciences Rennes - UMR 6118, F-35000 Rennes, France \\ ' Department of Geosciences, Boise State University, Idaho, ID 83725, USA \\ e Instituto de Investigación en Paleobiología y Geología, CONICET E Universidad Nacional de Río Negro, 8332 General Roca, Argentina \\ ${ }^{\mathrm{f}}$ School of Environmental Sciences, University of Hull, Hull HU6 7RX, UK \\ ${ }^{g}$ Department of Earth Sciences, University College London, London WC1E 6BT, UK \\ h Université de Lyon, UCBL, ENSL, CNRS, LGL TPE, Bâtiment Géode, 69622 Villeurbanne, France
}

\section{A R T I C L E I N F O}

\section{Article history:}

Received 5 October 2018

Received in revised form 6 January 2019

Accepted 8 January 2019

Available online 13 February 2019

Handling Editor: R.D. Nance

Keywords:

Western Gondwana

Neuquén Basin

Biostratigraphy

Geochronology

Cyclostratigraphy

Tethys

\begin{abstract}
A B S T R A C T
An integrated radio-astrochronological framework of the Agrio Formation in the Andean Neuquén Basin of westcentral Argentina provides new constraints on the age and the duration of the late Valanginian through Hauterivian stratigraphic interval. A CA-ID TIMS U-Pb age of $126.97 \pm 0.04(0.07)[0.15]$ Ma is presented here from the upper Hauterivian Agua de la Mula Member of the Agrio Formation. Biostratigraphic data from ammonoids and calcareous nannofossils and this high precision new radioisotopic age, together with three former ones from the same Agrio Formation are combined with new astrochronological data in the Andes. These are correlated with modern cyclostratigraphic studies in the classical sections of the Mediterranean Province of the Tethys, supporting detailed interhemispheric correlations for the Early Cretaceous. We also provide new $\delta^{13} \mathrm{C}$ data from the Agrio Formation which are compared with records from the classic Tethyan sections. According to our calibration, the minimum in the values in the mid-Hauterivian appears to be synchronous and, thus, another important stratigraphic marker for global correlation. A new duration of $5.21 \pm 0.08$ myr is calculated for the Hauterivian Stage, starting at 131.29 $\pm 0.19 \mathrm{Ma}$ and ending at $126.08 \pm 0.19 \mathrm{Ma}$. The difference between the duration of the Hauterivian in GTS2016 and in this study is 1.32 myr while the base and top of the GTS2016 Hauterivian differ respectively by 3.40 and 4.69 myr.
\end{abstract}

(c) 2019 International Association for Gondwana Research. Published by Elsevier B.V. All rights reserved.

\section{Introduction}

Uncertainty in the ages and durations of Early Cretaceous stages exists on the 2018 International Chronostratigraphic Chart (International Commission on Stratigraphy, IUGS) and the Geological Time Scale 2016 (Ogg et al., 2016). Besides, radioisotopic ages and astrochronological durations recently published conflict with those data (He et al., 2008; Gradstein et al., 2012; Vennari et al., 2014; Aguirre-Urreta et al., 2015, 2017; Martinez et al., 2015; Lena et al., 2019; Esmeray-Senlet et al., 2018). The Early Cretaceous stages are

\footnotetext{
* Corresponding author.

E-mail address: aguirre@gl.fcen.uba.ar (B. Aguirre-Urreta).
}

mostly defined in the Mediterranean Tethys by ammonite biostratigraphy and calcareous nannofossil bioevents calibrated with the M sequence of magnetic polarity chrons (Gradstein et al., 2012). However, the scarcity of tuffs in the Tethys and the lack of precise radiometric ages have hindered the construction of an accurate geological time scale. In particular, the durations of the Valanginian and the Hauterivian stages are presently under much debate, with great discrepancies between the numerical ages of the Geological Time Scale 2016 (Ogg et al., 2016) and the International Chronostratigraphic Chart 2018/8 (http://www.stratigraphy.org/ICSchart/ChronostratChart2018-08.pdf) with the biostratigraphic and radio-astrochronological studies made recently in the Andes (Aguirre-Urreta et al., 2015, 2017) and in the Tethys (Charbonnier et al., 2013; Martinez et al., 2013, 2015). 
The Neuquén Basin is a retro-arc basin developed at the foothills of the Argentine Andes in western Gondwana. The Agrio Formation is composed of mixed siliciclastic and carbonate rocks intercalated with tuff layers (Aguirre-Urreta et al., 2008a, 2015, 2017; Schwarz et al., 2016). The rich content of ammonoids and calcareous nannofossils allows dating the interval from the late early Valanginian to the late Hauterivian. The formation has been studied for more than 20 years for its faunal and microfossils content and correlated to the 'standard' Tethyan based on common assemblages (Aguirre-Urreta and Rawson, 1997; Aguirre-Urreta et al., 2005, 2007; Rawson, 2007; Bown and Concheyro, 2004; Lescano and Concheyro, 2014). The Agrio Formation thus provides a unique opportunity to produce an astronomical time scale anchored on CA-ID TIMS U-Pb ages, and to tie this absolute time scale to the 'standard' chronostratigraphy of the Western Tethys area.

The section selected in this study, the El Portón section, is expanded $(\sim 700 \mathrm{~m})$, shows all the ammonoid zones and calcareous nannofossil bioevents of the Neuquén succession, and contains two datable tuff layers. One of these has been recently dated with CA-ID TIMS U-Pb (Aguirre-Urreta et al., 2017). The data for another layer are introduced here. The magnetic susceptibility measurements, obtained from evenly sampled marl-limestone alternations, allowed the establishment of the first astrochronology directly anchored to U-Pb ages in the Early Cretaceous. In addition, new ammonoid data from the La Charce area and revised astrochronology from the La Charce and Río Argos sections from the Tethyan area are provided here. Bulk-rock stable isotopes were measured on the El Portón section and compared to the Tethyan sections to test the possibility of correlations based on stable isotopes. Thus, radiochronologic, astrochronologic, biostratigraphic, and isotopic data are integrated and correlated with those of the Mediterranean Tethys, including the candidates for the base of the Hauterivian ( $\mathrm{La}$ Charce) and the base of the Barremian (Río Argos).

The new geological time scale for the Valanginian-Hauterivian stages proposed here differs from GTS2016 and ICS Chart 2018/8 and provides important information that may assist to update this linear scale.

\section{Geological background}

\subsection{The Neuquén Basin and the Agrio Formation}

The Neuquén Basin is located in west-central Argentina between $32^{\circ}$ and $40^{\circ}$ south latitude along the eastern foothills of the Andes (Fig. 1.A). It is a retro-arc basin, more or less triangular in shape, with a complex history mainly controlled by the changing tectonic setting of the western margin of Gondwana (Ramos and Folguera, 2005). It encompasses a Late Triassic-early Cenozoic succession of several thousand meters of thickness of marine and continental sedimentary rocks.

The Lower Cretaceous deposits are included in the Mendoza and Bajada del Agrio Groups (Groeber, 1946; Méndez et al., 1995) (Fig. 1. B). The marine Tithonian-early Valanginian is represented by organicrich, dark shales with calcareous nodules (Vaca Muerta Formation) and thinly laminated limestones (Quintuco Formation). The paleogeography was complex, especially during the Valanginian, when a regression took place, and there was a coexistence of continental and volcaniclastic beds, marine shales and thick carbonate deposits of the Mulichinco and Chachao formations (Legarreta and Gulisano, 1989). A

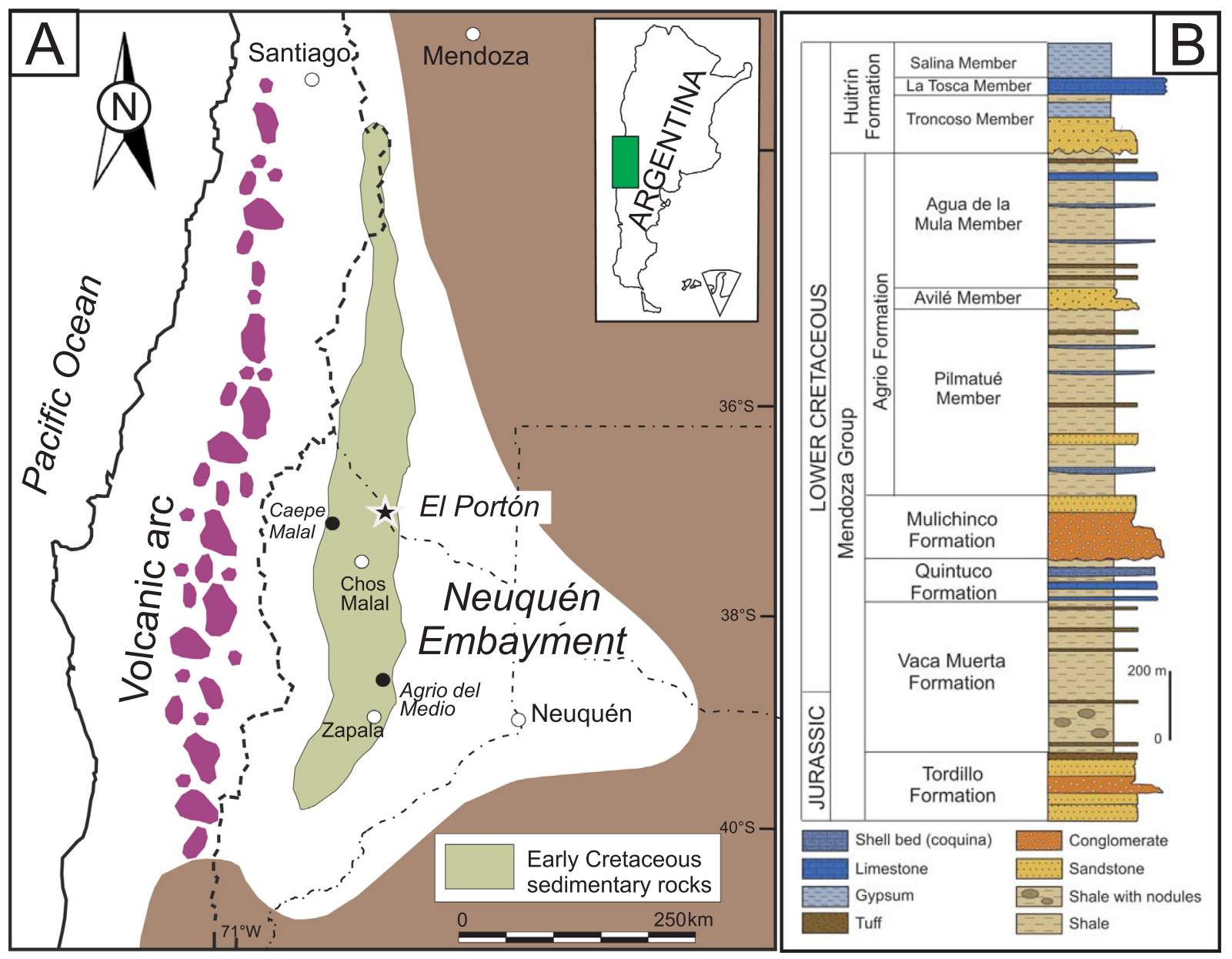


Mendoza Group and the Huitrín Formation. 
transgressive phase occurred in the late early Valanginian with the deposition of the shales, marls and limestones of the Agrio Formation. This unit was firstly described by Weaver (1931); it is up to $1300 \mathrm{~m}$ thick and is divided in three members (Leanza and Hugo, 2001). Both the Pilmatué and Agua de la Mula Members are marine, mainly composed of dark shales and silty shales interbedded with limestones and fine-grained calcareous sandstones containing an abundant invertebrate fauna. The middle Avilé Member is commonly represented by a thick package of yellowish coarse sandstones, often with crossbedding of fluvial and aeolian origin (Gulisano and Gutiérrez Pleimling, 1988). The Agrio Formation was deposited in a wide ramp environment, and accumulation fluctuated between periods of carbonate sedimentation and episodes of clastic aggradation (Legarreta and Uliana, 1991; Spalletti et al., 2001, 2011; Lazo et al., 2005). The fauna comprises mainly invertebrates and quite scarce vertebrates. Invertebrates are taxonomically diverse and include bivalves, gastropods, ammonoids, nautiloids, corals, bryozoans, serpulids, decapod crustacea, and echinoderms. Mollusks are abundant particularly in shell beds. The fauna has mainly Tethyan affinities, but some taxa have Andean affinities and even endemic taxa are present (Aguirre-Urreta et al., 2008b). The faunas indicate warm-temperate shallow waters (Lazo et al., 2005). Microfossils are represented by benthic foraminifers, ostracods, radiolarians and calcareous nannofossils (Ballent et al., 2011 and references therein).

The Agrio Formation is assigned a late early Valanginian to late Hauterivian age based on integrated studies on ammonoids, nannofossils and palynomorphs calibrated with U-Pb zircon ages (Aguirre-Urreta et al., 2005, 2007, 2015, 2017) and correlations with the Mediterranean Province of the Tethys have been recently updated (Reboulet et al., 2014, 2018; Martinez et al., 2015).

The Agrio Formation, the upper unit of the Mendoza Group, is followed by the fluvial and aeolian sandstones, evaporites and carbonates of the Huitrín Formation (Bajada del Agrio Group) which marks a regression and the commencement of the disconnection of the Neuquén Basin from the Pacific Ocean. Within this unit there is a package of intertidal to marine limestones, known as the La Tosca Member, which has fossils indicative of a short period of anomalous marine conditions during the early Barremian (Lescano et al., 2015; Lazo et al., 2017). These limited facies are developed within a general evaporitic sequence, which indicates a restricted connection with the Pacific Ocean.

\subsection{The Tethyan area (La Charce-Pommerol and Río Argos)}

The La Charce and the Río Argos sections are respectively the candidates of the Hauterivian and the Barremian GSSPs (Ogg et al., 2016).

The La Charce section is here completed by the Pommerol section; they are located in the Vocontian Basin, in southeastern France (Fig. 2. A). La Charce-Pommerol is a composite section composed of marllimestone alternations deposited in a hemipelagic environment. Two slumps in the lower Hauterivian of the La Charce section interrupt the continuity of the undisturbed marl-limestone alternation deposits. The stratigraphic interval equivalent to these two slumps was correlated to the nearby Pommerol section so that the lower Hauterivian is represented by a continuous composite series of undisturbed marl-limestone alternations.

Numerous ammonoids collected in the La Charce section allowed a detailed biostratigraphic scheme to be erected for the Valanginian and Hauterivian intervals (Reboulet et al., 1992; Bulot et al., 1993; Reboulet, 1996; Reboulet and Atrops, 1999). Additional ammonoid data are thus provided here from the Pommerol section and allow to establish more precisely the lower Hautervivian zonal scheme of this area. Calcareous nannofossil biostratigraphy (Thierstein, 1971; Gardin, 2008; Barbarin et al., 2012) and bulk-rock $\delta^{13} \mathrm{C}$ are available from the La Charce section. Spectral analyses on gamma-ray spectrometry measured every $20 \mathrm{~cm}$ allowed the construction of an astronomical time scale (Martinez et al., 2015), that we revise here in the light of the new results acquired in El Portón.

The Río Argos section is located in southeastern Spain in the Subbetic Domain (Fig. 2.B). The section is composed of hemipelagic marllimestone alternations, progressively evolving from terrigenous dominated to calcareous dominated. Numerous ammonoids collected in the Río Argos allowed detailed Tethyan biostratigraphic scheme to be built for the upper Hauterivian to the lower Barremian (Hoedemaeker and Leereveld, 1995; Company et al., 2003, 2005). In addition, calcareous nannofossil data are available in the section (Hoedemaeker and Leereveld, 1995; Aguado et al., 2014). Gamma-ray spectrometry,
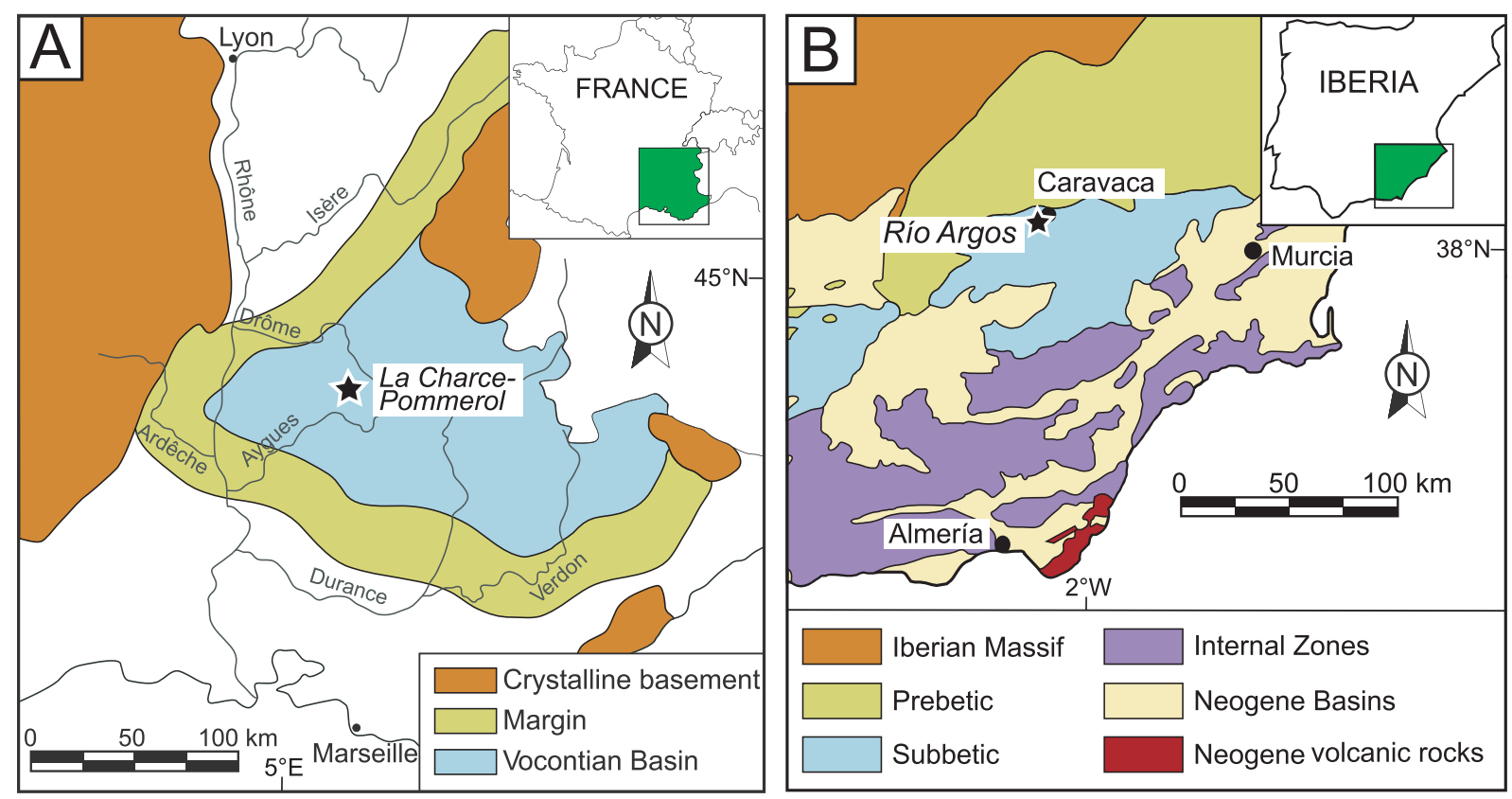

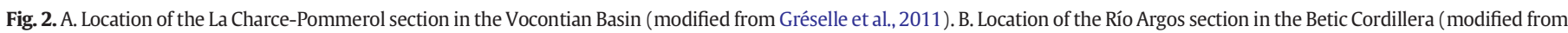
Martín et al., 2009). 
magnetic susceptibility and clay mineral measured every $20 \mathrm{~cm}$ allowed the construction of an astronomical time scale (Martinez et al., 2012, 2015; Moiroud et al., 2012), that we revise here in the light of the new results acquired in El Portón.

\section{Material and methods}

\subsection{Sedimentology}

The El Portón section $\left(37^{\circ} 11^{\prime} 52^{\prime \prime} \mathrm{S}, 69^{\circ} 41^{\prime} 03^{\prime \prime}\right.$ W) comprises more than $700 \mathrm{~m}$ of upper Valanginian through upper Hauterivian sediments. A total of 2130 samples was collected and subjected to various analyses in the laboratory. Twelve thin sections were prepared and described with polarized light. In addition, four of the thin-sections were analysed using the SEM. Limestones were classified following the classification of Embry and Klovan (1971).

\subsection{Paleontology}

\subsubsection{Ammonoids}

Ammonoids in the El Portón section are registered from 86 levels, 52 levels from the Pilmatué Member and 34 levels from the Agua de la Mula Member of the Agrio Formation. They are abundant and generally preserved as impressions in the limestones and only in very few horizons, especially in the lower part of the Pilmatué Member and in the upper section of the Agua de la Mula Member is the preservation 3-D, within calcareous nodules. In many levels, it was not possible to get precise systematic identifications up to the species level. The specimens were photographed, and initial identifications were done in the field which were later corroborated using appropriate literature in the laboratory.

The palaeontological material of the La Charce section (Reboulet et al., 1992; Reboulet, 1996; Reboulet and Atrops, 1999) has been recently complemented by the sampling of the Pommerol section (Noclin, 2017) in order to determine the distribution of the ammonoid fauna for the two stratigraphic intervals that are slumped at the La Charce area (1st slump, interval named LCH-215; 2nd slump, interval named LCH-241). To make easier the correlation between these two sites, the numbering of the Pommerol section (POM) follows that of the La Charce section ( $\mathrm{LCH}$ ). Thus, the layers of the first and second intervals of the Pommerol section, corresponding to the first and second slumps of the La Charce section, are named POM-215a to $215 \mathrm{~m}$ and POM-241a to 241p, respectively. The sampling of the macrofauna on the Pommerol section was carried out at 43 calcareous layers, from layers POM-213a to 223, and from layers POM-240 to 242. Dissolution of the ammonoid shells is common and specimens are preserved as internal calcareous moulds. The ammonoid fauna is relatively well preserved, but specimens are frequently fragmented and compacted in some layers. Consequently, some characteristics, such as the whorl section, the strength of ribs and tubercles, and how they change between the inner and outer whorls, cannot be observed and compared for some specimens. The identification of ammonoids at specific level is sometimes difficult or impossible. Some data are here presented at the generic level and some specimens identified with doubt are indicated by a question mark.

\subsubsection{Calcareous nannofossils}

In this study, 103 levels from the El Portón section, 43 from the Pilmatué Member and 60 from the Agua de la Mula Member of the Agrio Formation were examined for their content of calcareous nannofossils. Samples were prepared following the smear slide technique (Edwards, 1963) and the slides were fixed with UV curing Norland Optical Adhesive. Identification and photographs were carried out using a Leica DMLP petrographic microscope with 1000× magnification and accessories as lambda gypsum plate. Slides were examined in order to identify all taxa that may have biostratigraphic or biogeographic significance. Identification followed the taxonomic criteria of Perch-Nielsen (1985) and the guidelines proposed by Bown and Young (1997). Calcareous nannofossil slides are housed in the Area Paleontología, Facultad de Ciencias Exactas y Naturales, Universidad de Buenos Aires, under catalog numbers BAFC-NP 3992-4034 and 4039-4098.

\subsection{Astrochronology}

Bulk-rock samples have been collected at $25 \mathrm{~cm}$ intervals in the El Portón section, totaling 2130. Samples were crushed, cut from their weathered surfaces, and weighted prior to the magnetic-susceptibility (MS) measurements. The volumic MS measurements were conducted on a KLY-2 available at the University of Bremen. Measurements were corrected for blank values and normalized to the sample mass. Due to unknown sample density and difficult to determine sample volumes, the numbers indicated by the KLY-2 were normalized to sample mass, resulting in units $\mathrm{kg}^{-1}$ for MS. Replicates were performed on $781 \mathrm{sam}-$ ples (ca. $1 / 3$ of studied samples). On average, the variability of the MS measurements is $1 \%$ of the MS value.

Spectral analyses were performed on the MS series. Prior to the spectral analyses, depths were corrected from event deposits (typically tuff layers and sandstones), as they represent instant deposits. The longterm trends were subtracted from the series. Evolutive spectral analyses were performed using the Time-Frequency Weighted Fast Fourier Transform (TF-WFFT; Martinez et al., 2013, 2015) to determine the evolution of the sedimentary intervals throughout the studied series. The method consists in performing a weighted Fast Fourier Transform (FFT) on subintervals of the studied series, referred as windows hereafter and to stack the spectra to obtain a 3-dimension spectrum called a spectrogram. The subintervals are weighted using one Slepian sequence. After the FFT is done on a subinterval, the spectral background is calculated and removed from the spectrum to whiten the noise and increase the expression of high frequencies which is not clear in case of strong spectral redness. This treatment was particularly useful for La Charce-Pommerol and Río Argos. Intervals of the El Portón section did not show significant cycles at high frequencies and thus this treatment was not applied to the MS signal of El Portón. On the spectrograms shown here, blue colours correspond to the spectral background, while warm colours represent the spectral peaks. Spectra of specific intervals were calculated using the multi-taper method using three $2 \pi$-tapers

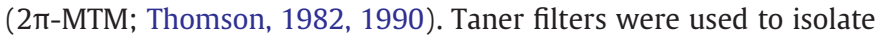
the frequency of interest (Taner, 2003), and bound the repetitions of the cycle used for calibration. The durations of deposit of the sedimentary series and of the stratigraphic intervals (stages, substages, ammonoid zones and subzones) were calculated assuming a constant sedimentation rate between each repetition of the calibration cycle, whose period is known from astronomical models (Laskar et al., 2004; Waltham, 2015).

\subsection{U-Pb zircon geochronology}

Ash samples were collected from cleaned bedding planes to avoid contamination with soil and surrounding sedimentary rocks. The laboratory analyses were done at Boise State University. A sample with abundant and relatively large (approximately $100-300 \mu \mathrm{m}$ in long dimension), mostly equant, prismatic zircon crystals was separated from a hand sample of tuff EP 1711-1712 by conventional density and magnetic methods. The entire zircon separate was placed in a muffle furnace at $900{ }^{\circ} \mathrm{C}$ for $60 \mathrm{~h}$ in quartz beakers to anneal minor radiation damage; annealing enhances cathodoluminescence (CL) emission (Nasdala et al., 2002), promotes more reproducible interelement fractionation during laser ablation inductively coupled plasma mass spectrometry (LAICPMS) (Allen and Campbell, 2012), and prepares the crystals for subsequent chemical abrasion isotope dilution thermal ionization mass spectrometry (CA-IDTIMS) (Mattinson, 2005). Following annealing, 
individual grains were hand-picked and mounted, polished and imaged by cathodoluminence (CL) on a scanning electron microscope. From these compiled images, grains with consistent and dominant CL patterns were selected for further isotopic analysis by LA-ICPMS and CAIDTIMS.

LA-ICPMS analysis utilized an X-Series II quadrupole ICPMS and New Wave Research UP-213 Nd:YAG UV (213 nm) laser ablation system. Inhouse analytical protocols, standard materials, and data reduction software were used for acquisition and calibration of $\mathrm{U}-\mathrm{Pb}$ dates and a suite of high field strength elements (HFSE) and rare earth elements (REE). Zircon was ablated with a laser spot of $25 \mu \mathrm{m}$ wide using fluence and pulse rates of $\sim 5 \mathrm{~J} / \mathrm{cm}^{2}$ and $10 \mathrm{~Hz}$, during a 45 second analysis (15 s gas blank, $30 \mathrm{~s}$ ablation) that excavated a pit $\sim 25 \mu \mathrm{m}$ deep. Ablated material was carried by a $1.2 \mathrm{~L} / \mathrm{min}$ He gas stream to the nebulizer flow of the plasma. Quadrupole dwell times were $5 \mathrm{~ms}$ for Si and Zr, $200 \mathrm{~ms}$ for ${ }^{49} \mathrm{Ti}$ and ${ }^{207} \mathrm{~Pb}, 80 \mathrm{~ms}$ for ${ }^{206} \mathrm{~Pb}, 40 \mathrm{~ms}$ for ${ }^{202} \mathrm{Hg},{ }^{204} \mathrm{~Pb},{ }^{208} \mathrm{~Pb},{ }^{232} \mathrm{Th}$, and ${ }^{238} \mathrm{U}$ and $10 \mathrm{~ms}$ for all other HFSE and REE; total sweep duration is $950 \mathrm{~ms}$. Background count rates for each analyte were obtained prior to each spot analysis and subtracted from the raw count rate for each analyte. For concentration calculations, background-subtracted count rates for each analyte were internally normalized to ${ }^{29} \mathrm{Si}$ and calibrated with respect to NIST SRM-610 and -612 glasses as the primary standards. Ablations pits that appear to have intersected glass or mineral inclusions were identified based on $\mathrm{Ti}$ and $\mathrm{P}$ signal excursions, and associated sweeps were generally discarded. Signals at mass 204 were normally indistinguishable from zero following subtraction of mercury backgrounds measured during the gas blank ( $\left.<100 \mathrm{cps}{ }^{202} \mathrm{Hg}\right)$, and thus dates are reported without common $\mathrm{Pb}$ correction. Rare analyses that appear contaminated by common $\mathrm{Pb}$ were rejected based on mass 204 greater than baseline. Temperature was calculated from the Ti-in-zircon thermometer (Watson et al., 2006). Because there are no constraints on the activity of $\mathrm{TiO}_{2}$ in the source rocks, a nominal value of 0.55 for high-silica rhyolites was used.

For LA-ICPMS U-Pb and ${ }^{207} \mathrm{~Pb} /{ }^{206} \mathrm{~Pb}$ dates, instrumental fractionation of the background-subtracted ratios was corrected, and dates were calibrated with respect to interspersed measurements of zircon standards and reference materials. The primary standard Plešovice zircon (Sláma et al., 2008) was used to monitor time-dependent instrumental fractionation based on two analyses for every 10 analyses of unknown zircon. A polynomial fit to the primary standard analyses versus time yields each sample-specific fractionation factor. A secondary bias correction is subsequently applied to unknowns on the basis of the residual age bias as a function of radiogenic $\mathrm{Pb}$ count rate in standard materials including Seiland, Zirconia, and Plesovice zircon, or similar materials of known age and variable $\mathrm{Pb}$ content. A polynomial fit to the secondary standard analyses with $\mathrm{Pb}$ count rate yields each samplespecific bias correction. Radiogenic isotope ratio and age error propagation for all analyses includes uncertainty contributions from counting statistics and background subtraction. For weighted mean calculations, the uncertainties in the primary standard calibration should be propagated into the errors on each date. These uncertainties are the local standard deviations of the polynomial fits to the interspersed primary standard measurements versus time for the time-dependent, relatively larger $\mathrm{U} / \mathrm{Pb}$ fractionation factor, and the standard errors of the means of the consistently time-invariant and smaller ${ }^{207} \mathrm{~Pb} /{ }^{206} \mathrm{~Pb}$ fractionation factor. These uncertainties are $\sim 2 \%(2 \sigma)$ for ${ }^{206} \mathrm{~Pb} /{ }^{238} \mathrm{U}$ and $\sim 1 \%(2 \sigma)$ for ${ }^{207} \mathrm{~Pb} /{ }^{206} \mathrm{~Pb}$. Additional details of methodology and reproducibility are reported in Rivera et al. (2013).

For CA-IDTIMS U-Pb geochronology, the methods follow those previously published by Davydov et al. (2010) and Schmitz and Davydov (2012). Zircon crystals were subjected to a modified version of the chemical abrasion method of Mattinson (2005), whereby single crystal fragments plucked from grain mounts were individually abraded in a single step with concentrated $\mathrm{HF}$ at $190{ }^{\circ} \mathrm{C}$ for $12 \mathrm{~h}$. All analyses were undertaken on crystals previously mounted, polished and imaged by cathodoluminence $(\mathrm{CL})$, and selected on the basis of zoning patterns.
$\mathrm{U}-\mathrm{Pb}$ dates and uncertainties for each analysis were calculated using the algorithms of Schmitz and Schoene (2007) and the U decay constants of Jaffey et al. (1971). Uncertainties are based upon nonsystematic analytical errors, including counting statistics, instrumental fractionation, tracer subtraction, and blank subtraction. These error estimates should be considered when comparing our ${ }^{206} \mathrm{~Pb} /{ }^{238} \mathrm{U}$ dates with those from other laboratories that used tracer solutions calibrated against the EARTHTIME gravimetric standards. When comparing our dates with those derived from other decay schemes (e.g., ${ }^{40} \mathrm{Ar} /{ }^{39} \mathrm{Ar}$, $\left.{ }^{187} \mathrm{Re}^{187} \mathrm{Os}\right)$, the uncertainties in tracer calibration (0.03\%; Condon et al., 2015; McLean et al., 2015) and U decay constants (0.108\%; Jaffey et al., 1971) should be added to the internal error in quadrature. Quoted errors for calculated weighted means are thus of the form $\pm X(Y)[Z]$, where $\mathrm{X}$ is solely analytical uncertainty, $\mathrm{Y}$ is the combined analytical and tracer uncertainty, and $\mathrm{Z}$ is the combined analytical, tracer and ${ }^{238} \mathrm{U}$ decay constant uncertainty.

\subsection{Carbon isotopes}

A total of 173 bulk-rock samples were collected; each was ground to a fine powder in an agate mill. Ten of the samples were discarded due to low carbonate content, so that the carbon stable isotopes of 163 bulkrock samples have been analysed. Samples were measured on a Finnigan MAT251 gas isotope ratio mass spectrometer connected to a Kiel I automated carbonate preparation device at the University of Bremen (data on Table 1, Supplementary information). Data are reported in the usual delta-notation versus V-PDB. The instrument was calibrated against the house standard (ground Solnhofen limestone), which in turn was calibrated against the NBS 19 standard reference material. Over the measurement period the standard deviation of the house standard was $0.03 \%$ for $\delta^{13} \mathrm{C}$.The trends of $\delta^{13} \mathrm{C}$ series were calculated using a LOWESS fit over $10 \%$ of the datasets.

\section{Results}

\subsection{Lithologic description of the El Portón section}

Lithology, sedimentary structures, bed geometries and fossil content were recorded and used to evaluate the depositional environments of the Agrio Formation (Figs. 3-6). Six facies were identified:

1. Calcareous shale (Csh): Packages of mainly light grey to dark grey thin laminated shales that can reach up to $10 \mathrm{~m}$ in thickness. Flattened ammonoids and scarce inoceramids moulds were found in this facies (Figs. 5.G, 6.H). The $\mathrm{CaCO}_{3}$ content of these levels is close to $50 \%$ with $20 \%$ of quartz and $10 \%$ of clays, based on XRD analyses. These values were also corroborated with EDS analyses (Voglino, 2017). TOC analyses on these levels show values between $0.23 \%$ and 3.59\% (Omarini et al., 2018). This facies was deposited under uninterrupted suspension settling.

2. Black shale $(\mathrm{Bm})$ : Thin to medium black to dark grey shale beds ( 0.25 to $2 \mathrm{~m}$ ) with conspicuous horizontal lamination and remarkable fissility (Fig. 5.C). Freshly broken, the rocks smell characteristically of oil. In the lower section, several levels with the benthic foraminifer Epistomina sp. were recognized. Calcareous nannofossils, clays and framboidal pyrite were observed using SEM on samples from this facies. This facies was deposited under uninterrupted suspension settling. The presence of pyrite and the high content of organic matter suggest anoxic bottom water during its deposition.

3. Mudstone and wackestone $(\mathrm{Cm})$ : Tabular, mainly massive bodies from $0.50 \mathrm{~m}$ up to $7 \mathrm{~m}$ in thickness. They are light grey or blue grey with typical light blue colour when weathered. The massive mudstones predominate over the laminated ones and also over the bioclastic wackestones. The bioclasts are very fragmented bivalves and ammonoids preserved as moulds. Scarce levels with Thalassinoides isp. were also identified (Fig. 5.H). On thin sections 
(Fig. 6.A-D), the main component is micritic non-ferroan calcite with scarce fragmented bivalves and disseminated calcispheres (sample PO 21). TOC analyses on these levels show values between $0.24 \%$ and $4.09 \%$ (Omarini et al., 2018). This facies was deposited in a low energy environment with high production of carbonate and decantation as the main sedimentary process. Nevertheless, the presence of bioclastic wackestones reveals the action of distal currents.

4. Tuff (T): The tuffs in the El Portón section range from tuffaceous massive sandstones and siltstones to altered vitroclastic tuffs (Figs. 5.A,E, 6.E). They have been recorded all along the section and show variable thickness from 0.2 to $0.45 \mathrm{~m}$, they are friable and commonly altered to calcite or clay. In thin sections, the tuffs show altered feldspar grains, highly deformed biotite and cuspate and pumice shards. Some shards are completely replaced by nonferroan calcite and others by kaolinite, which also acts as cement (samples PO 30X and PO 31A). This facies indicates that the volcanic arc was active during the deposition of the Agrio Formation.

5. Lutite $(\mathrm{Cl})$. Massive grey and green claystone/siltstone in thin beds partially covered (Fig. 6.F) interbedded with massive sandstones (Sm) (see below). No fossils were found. This facies can be interpreted as the fallout of clay and silt from pro-delta plumes.

6. Massive sandstone ( $\mathrm{Sm})$. Green to yellow massive medium-grained sandstones with some beds with convolute lamination (Figs. 5.D, 6. $\mathrm{G})$. The beds are 0.35 to $0.50 \mathrm{~m}$ thick. This facies is interpreted as the deposit from flows stretching from the river mouth along the shoreface. The absence of substantial traction caused the sudden settling of the coarse-grained sediment load.

Both the Pilmatué and the Agua de la Mula members were deposited in an outer ramp environment (Legarreta and Uliana, 1991; Spalletti et al., 2011 and references therein). The alternation of levels dominated by limestones with levels dominated by siliciclastic sediments is a consequence of fluctuation of times of high carbonate productivity versus times with high terrigenous input (Sagasti, 2000, 2005; Comerio et al., 2018). The non-marine Avilé Member in between is connected to a short episode of shallowing related to a forced regression; in El Portón it is composed of $130 \mathrm{~m}$ of lutites and sandstones deposited in an ephemeral lacustrine and fluvial environment (Rossi, 2001). In this section, the upper $40 \mathrm{~m}$ of the Agua de la Mula Member show the transition to the overlying Huitrín Formation.

\subsection{Biostratigraphy}

\subsubsection{Ammonoids}

4.2.1.1. El Portón. All the Andean ammonoid biozones from the late Valanginian up to the late Hauterivian have been recognized (Fig. 3.AB) and some characteristic species, especially from the Agua de la Mula Member are illustrated in Fig. 7 (see also illustrations in Fig. 7 in Aguirre-Urreta et al., 2017, for representative species of the Pilmatué Member). At most horizons the taxonomic diversity is low and individual assemblages are generally monogeneric or even monospecific. The Andean zonal scheme is built with Assemblage zones (AZ), Consecutive-Range zones (CRZ) and Local Range zones (LRZ).

The following four ammonoid biozones have been recognized in the Pilmatué Member of the Agrio Formation at El Portón, from base to top:

- The Pseudofavrella angulatiformis AZ (late Valanginian): Three subzones are recognized. The $P$. angulatiformis Subzone at the base contains a Pseudofavrella assemblage, preserved as abundant flattened impressions in shales associated with the last Viluceras permolestus. The second subzone is the Chacantuceras ornatum Subzone whose upper limit is difficult to define due to poor preservation. The third subzone is the Decliveites crassicostatum Subzone and records two species of involute and compressed neocomitids: $D$. crassicostatum in the lower part and $D$. agrioensis in the upper part.
- The Holcoptychites neuquensis AZ (early Hauterivian): Abundant and well-preserved impressions of $H$. magdalenae appear in several horizons which characterize the lower $H$. neuquensis Subzone. The middle subzone is characterized only by the index species, the more compressed and involute Holcoptychites agrioensis. Above comes the Olcostephanus (O.) laticosta Subzone which is well distinguished by several small specimens of the index species.

- The Hoplitocrioceras gentilii AZ (early Hauterivian): Abundant, well preserved impressions of Hoplitocrioceras giovinei below are replaced upwards by the more compressed form, $H$. gentilii.

- The Weavericeras vacaense AZ (early Hauterivian): The genus Weavericeras is represented in El Portón by abundant but very poorly preserved specimens and no other ammonites have yet been discovered in this zone.

In the Agua de la Mula Member of the Agrio Formation at El Portón, five ammonoid biozones have been recognized, from base to top:

- The Spitidiscus riccardii AZ (late Hauterivian): This biozone is documented in bluish-black shales, here Spitidiscus spp. are recorded both as flattened in the shales and as very small specimens preserved in $3 \mathrm{D}$.

- The Crioceratites schlagintweiti CRZ (late Hauterivian): It includes those beds immediately above the Spitidiscus riccardii zone in which Crioceratites schlagintweiti appears. This species is well represented in several levels with numerous specimens in each one, mostly preserved as impressions.

- The Crioceratites diamantensis CRZ (late Hauterivian): The nominal species is common in the section, and its first appearance defines the base of the biozone. Other species in at least 20 levels are also present such as "Crioceratites" bederi, "C." andinus and "C." perditus, together with new taxa under study still to be named.

- The Paraspiticeras groeberi LRZ (late Hauterivian): This zone represents a discrete fauna occurring above the Crioceratites-bearing beds, with the base of the zone marked by the first appearance of Paraspiticeras. In El Portón there are several horizons with this species and three of them preserves quite abundant, well preserved 3D specimens of Paraspiticeras groeberi.

- The Sabaudiella riverorum LRZ (late Hauterivian): The index species has only been registered from a single well-preserved 3D specimen at El Portón.

The Valanginian-Hauterivian ammonoid zonal scheme of the Neuquén Basin is based on the early work of Aguirre-Urreta and Rawson (1997). Several subsequent modifications of this biozonation emerged as their monographic description of most of the faunas of the Pilmatué Member of the Agrio Formation progressed; those modifications were summarized in Aguirre-Urreta et al. (2005, 2007). During Valanginian and early Hauterivian times there were several significant ammonite faunal turnovers in the Neuquén Basin reflecting an alternation of neocomitid and olcostephanid genera (Rawson, 2007). The modern studies of these Andean ammonoids permitted the correlation of the Austral zones and those of the Tethys (see Reboulet et al., 2014, their Table 5, and next subsection).

The lowermost and uppermost faunas of the Agua de la Mula Member have been recently investigated (Aguirre-Urreta and Rawson, 2012; Rawson and Aguirre-Urreta, 2012), but many of the heteromorphs that dominate most of the succession are still under study. This lack of modern systematics has hindered the correct correlation of the Neuquén fauna with the "standard" zonation of the West Mediterranean Province of the Tethys and that presented in Reboulet et al. (2014) is partially rectified here on the light of the new studies in progress.

The sudden appearance of Spitidiscus in Argentina, immediately above the non-marine Avilé sandstones, is associated with a maximum 

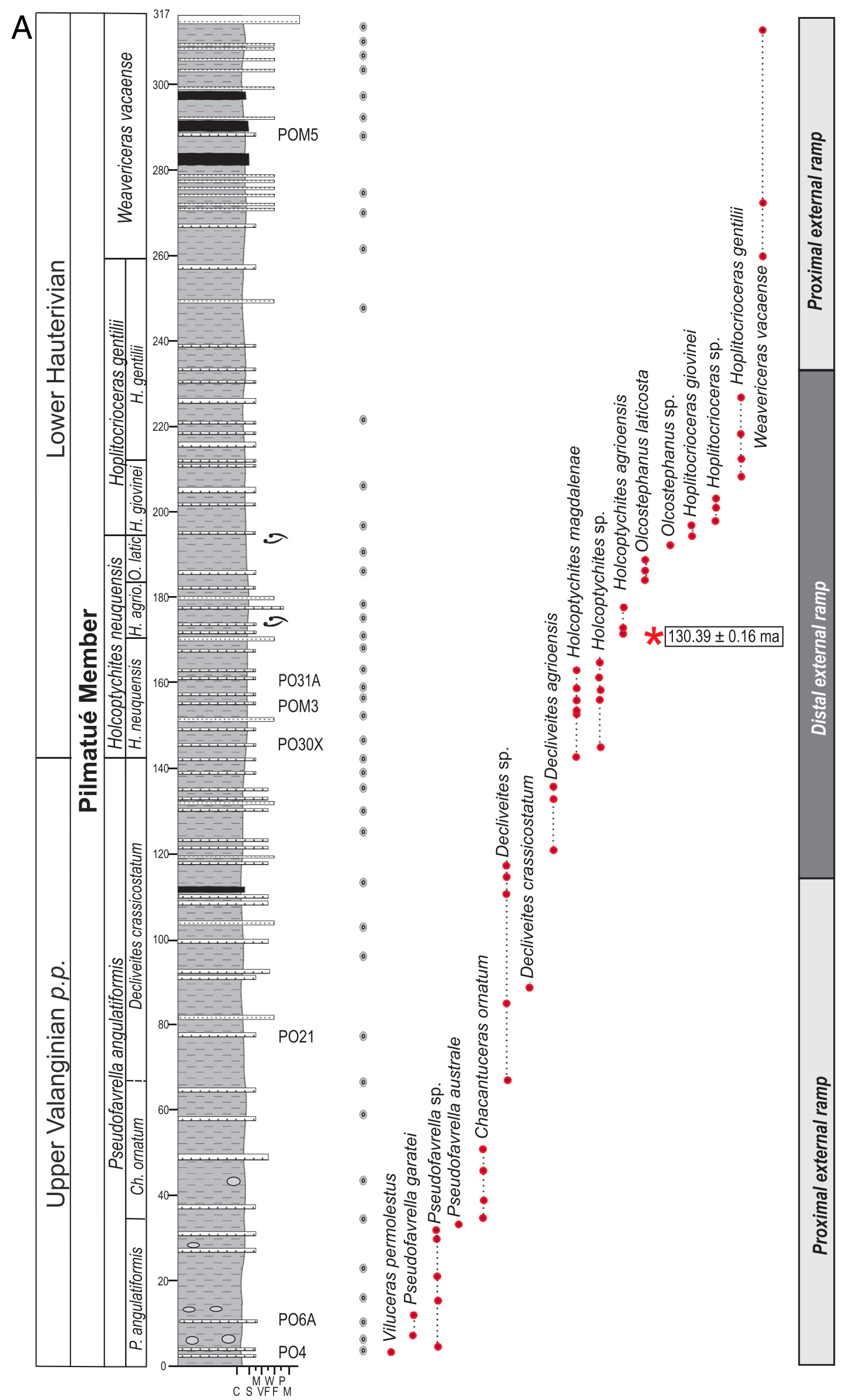


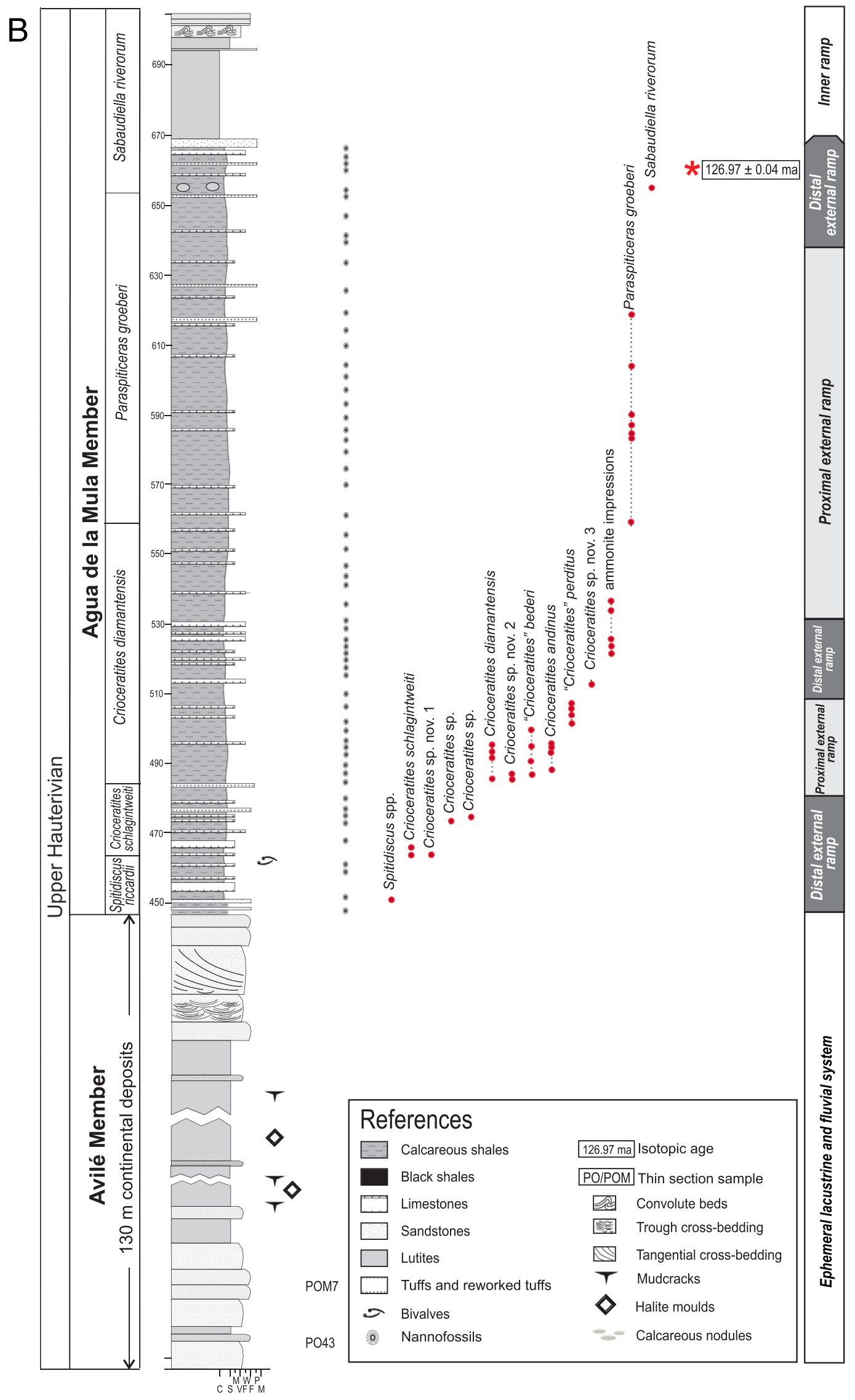

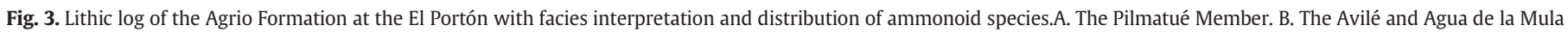
Members. 

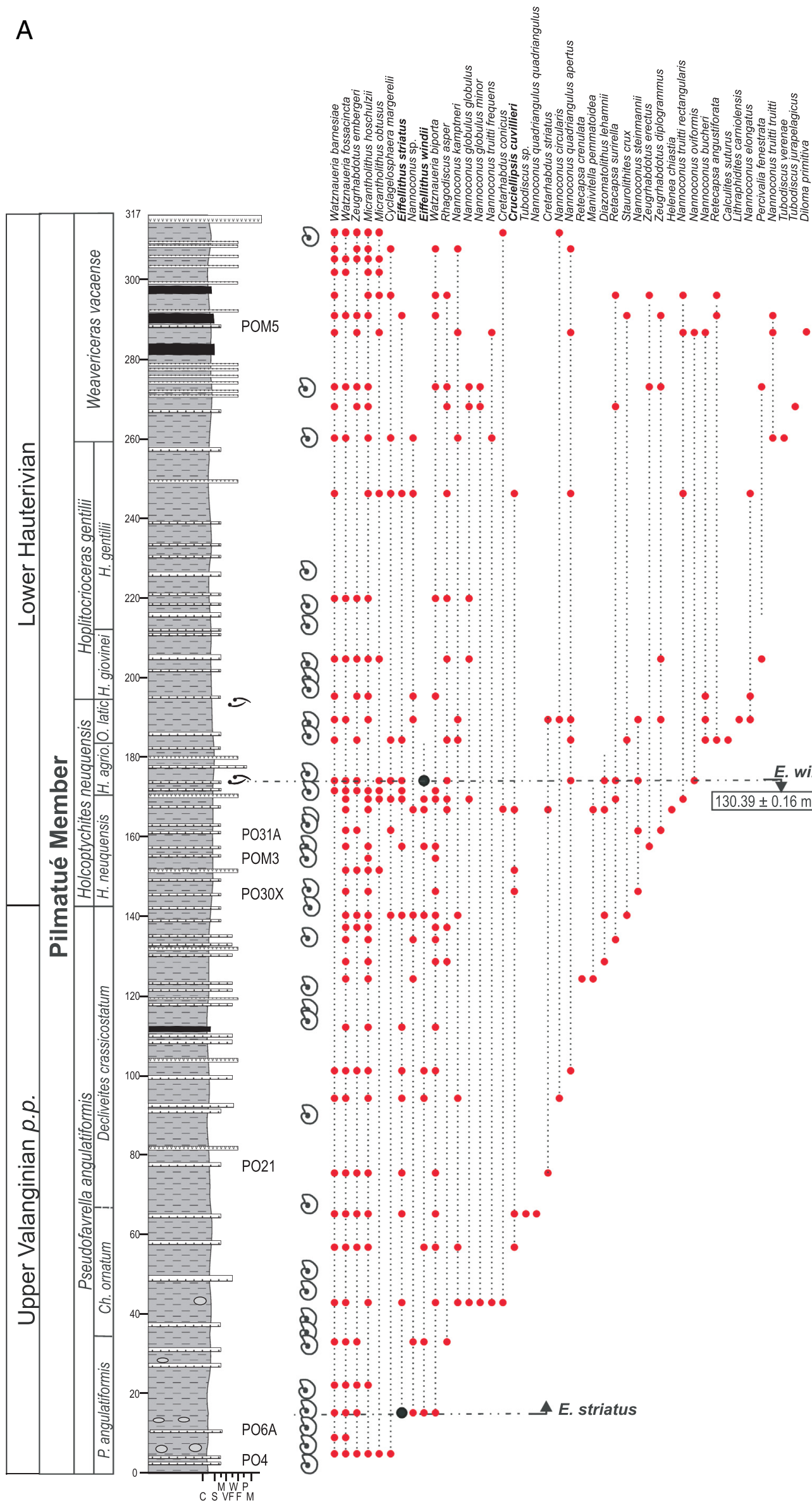

๑)

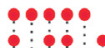

0

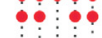

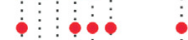
بी

厄)

ठ)

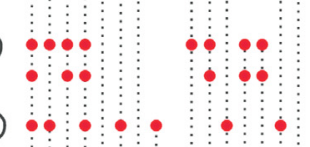

๑)

๑

ठ

8

(5)

8.

8.

(2)

\&ิ

8 0

อ

ठ

อ

8

0

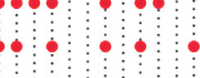

ठ

Q

(2)

(2)

Ua

8.

है

0

(1) 
B

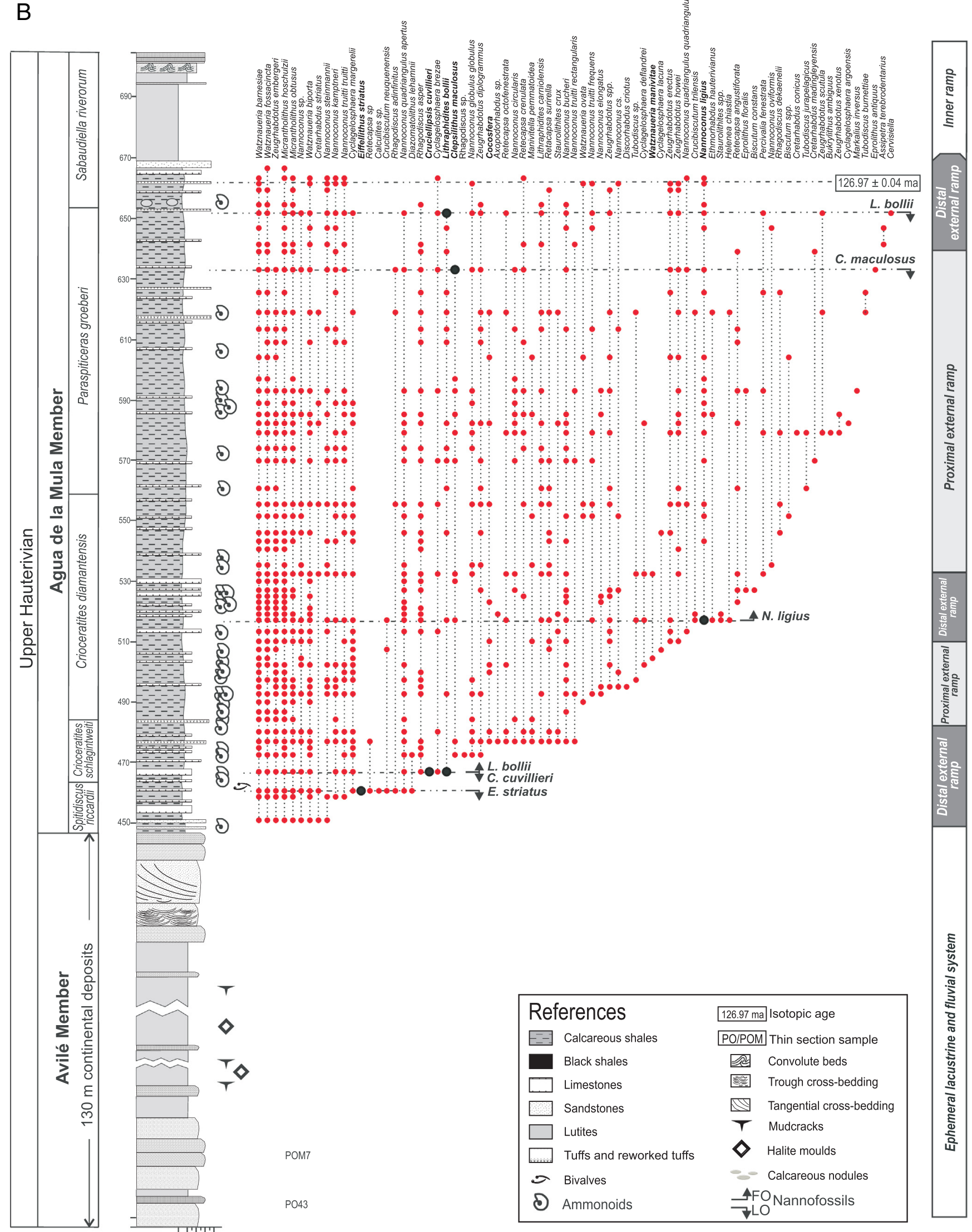

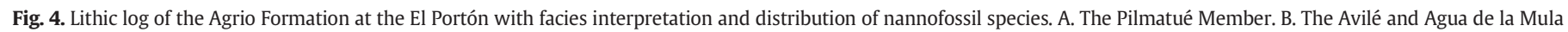
Members. 


flooding surface widespread in the basin. It is a local reflection of the main "mid" Hauterivian sea level rise (Rawson, 1993, 2007) and thus, the Spitidiscus riccardii Zone is correlated with the Subsaynella sayni Zone, which marks the base of the upper Hauterivian in the Tethys. The crioceratitids of the overlying Crioceratites schlagintweiti Zone, some of which are close with forms ( $C$. nolani and $C$. duvali) in the S. sayni Zone of the West Mediterranean Province, supports these correlations. A varied plexus of heteromorph ammonoids characterizes most of the remainder of the Agua de La Mula Member. Crioceratites diamantensis, the nominal species of the following biozone is associated with several other local species of crioceratitids such as "C." bederi, "C." perditus, and "C." andinus. Vermeulen (2004) erected the genus Diamanticeras for $C$. diamantensis but pending taxonomic revision of the fauna the validity of this genus remains uncertain. The Crioceratites of the diamantensis Zone have diverged from their Mediterranean counterparts in some aspects and evolved locally in the basin, and though initially correlated with the $B$. balearis Mediterranean Zone, this fauna may be contemporary with the upper part of the S. sayni Zone and most of the P. ligatus Zone.

Paraspiticeras and Sabaudiella, the two genera which characterize the two following biozones are present in the Tethys where they are minor components of the late Hauterivian-early Barremian ammonoid fauna (Cecca et al., 1998; Company et al., 2005, 2008; Baudin et al., 2006). As they have not been studied in detail in the classic European sections, their age in the basin in relation to the Tethys is difficult to assess accurately. The Paraspiticeras groeberi Zone has been correlated with part of the Pseudothurmannia ohmi Zone and the Sabaudiella riverorum zone with its upper part (Reboulet et al., 2014), but other correlations are also possible. For instance, the first record of Paraspiticeras is in the upper part of the Balearites balearis Subzone in the Betic Cordillera, Spain (Company et al., 2003) and thus this can be used to correlate the P. groeberi Zone to the B. balearis zone. Busnardo et al. (2003, p. 80) reported the record of $S$. simplex below its occurrence in bed 92.2 (Poisons bed), together with S. sabaudiana in the "Pseudothurmannia angulicostata auct." Zone [presently P. ohmi], based on material from Veveyse de Châtel, Switzerland. This bed corresponds to the shortlived Faraoni event (Baudin et al., 2006), which is located in the base of the Pseudothurmannia mortilleti Subzone and then it may well imply that the Sabaudiella riverorum Zone may reach this age.

4.2.1.2. La Charce-Pommerol. For the La Charce-Pommerol composite section, the standard zonation built by the IUGS Kilian Group (Hoedemaeker et al., 2003; Reboulet et al., 2018) is applied. This zonal scheme is suitable for the Mediterranean Province of the Mediterranean-Caucasian Subrealm (Tethyan Realm) sensu Westermann (2000) and Lehmann et al. (2015). Since the first international meeting (Hoedemaeker et al., 1990), the Kilian Group prefers to use interval zones to build the Lower Cretaceous standard zonation; all (sub-)zones evoked here are defined at their base by the First Appearance Datum (FAD) of the index-species.

The systematic and distribution of the ammonoid fauna of the La Charce section and the biostratigraphic implications for the Valanginian and lower Hauterivian have been well described by Reboulet et al. (1992), Reboulet (1996) and Reboulet and Atrops (1999). Thus, only the results of the Pommerol section (early Hauterivian) are presented here. The ammonoid fauna of this section consists of sixteen genera grouped into nine families (Appendix 1 in Supplementary material), mainly using the classification proposed by Klein (2005), Klein et al. (2007, 2009), and Klein and Vašiček (2011). Further information on the systematic and stratigraphic distributions of taxa characterising the zones are given in the papers of Ropolo (1991), Reboulet et al.
(1992), Bulot et al. (1993), Bulot (1995), Reboulet (1996), Reboulet and Atrops (1999), and Busnardo et al. (2003).

Neocomitidae (Breistrofferella, Leopoldia, Saynella, Lyticoceras, Teschenites and Spitidiscus) and Olcostephanidae (Olcostephanus and Jeannoticeras) are relatively frequent (175 and 109 specimens, respectively) on the Pommerol section (Fig. 8). Breistrofferella (rare), Leopoldia (rare) and Teschenites (common) occur only in the first sampled stratigraphic interval; Lyticoceras and Jeannoticeras are common and recorded in the second sampled interval. Spitidiscus and Olcostephanus are common to frequent in both intervals. Among other families, heteromorphs are represented by Crioceratites (common) and Bochianites (rare, except in layers $215 \mathrm{i}, \mathrm{j}, \mathrm{k}$ ). Oosterella (rare) and Abrytusites (rare) have been found in the first and second intervals, respectively. Neolissoceras, Phyllopachyceras, Phylloceras (Hypophylloceras) and Lytoceras are relatively frequent along the section.

At the Pommerol section, the upper part of the Acanthodiscus radiatus Zone is well characterized by the occurrences of Breistrofferella varappensis, B. castellanensis, Leopoldia leopoldina, Teschenites flucticulus, Spitidiscus meneghini, S. lorioli, Olcostephanus densicostatus and Oosterella sp. (Fig. 8). The base of the Crioceratites loryi (Sub-)Zone is placed at the first occurrence of the index-species in layer POM-219; this event takes place in the same layer at the La Charce section $(\mathrm{LCH}-$ 219). In the lowermost part of the zone, the first occurrence of Olcostephanus sayni is observed. The upper part of the C. loryi Zone is characterized by the occurrence of Jeannoticeras jeannoti which is the index-species of the second subzone. The boundary between the C. loryi-J. jeannoti subzones is placed on the Pommerol section by correlation with the La Charce section (base of layer LCH/POM232, at the top of the Loryi calcareous bundle). In the J. jeannoti Subzone of the Pommerol section, Spitidiscus incertus, Abrytusites julianyi and Crioceratites curnieri have been also recorded. The base of the Lyticoceras nodosoplicatum Zone is put at the base of layer POM$241 \mathrm{f}$ where the index-species is found. Only the lower part of the zone is represented; it is mainly characterized by Olcostephanus variegatus, Plesiospitidiscus fasciger, Spitidiscus rawsoni, J. jeannoti and C. curnieri.

\subsubsection{Calcareous nannofossils of the El Portón section}

The nannofloristic assemblage recovered from the Agrio Formation at El Portón is moderately preserved, and represented by 68 species, belonging to 30 genera (see Fig. 4.A-B). Some characteristic species, especially from the Agua de la Mula Member are illustrated in Fig. 9 (see also Fig. 9 in Aguirre-Urreta et al., 2017, for representative species of the Pilmatué Member).

The assemblages include a number of markers (Eiffellithus windii, Eiffellithus striatus, Cruciellipsis cuvillieri, Lithraphidites bollii, Clepsilithus maculosus and Nannoconus ligius), although others were not recognized (e.g. Speetonia colligata). The first and last occurrences (FOs and LOs) of these marker species allowed the definition of some bioevents; two of them have been identified in the Pilmatué Member and six have been recognized in the Agua de la Mula Member. Most of these bioevents have been used to identify the zones/subzones CC3B, CC4A, CC4B and CC5 of the Mediterranean Tethys (Sissingh, 1977; Applegate and Bergen, 1988). In addition, the LO of Clepsilithus maculosus, considered a Boreal bioevent (Rutledge and Bown, 1996) has also been recognized herein.

We have identified bioevents with different stratigraphic confidence, and these can be correlated with ammonoid zones (AguirreUrreta et al., 2005, 2017; Concheyro et al., 2009; Lescano and Concheyro, 2014). A discussion of the eight nannofossil bioevents recognized in the study is presented below.

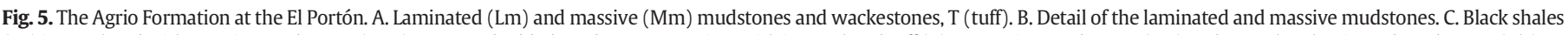

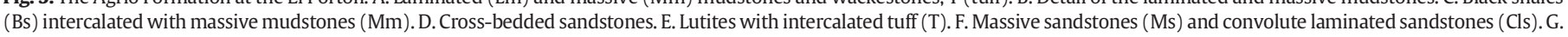
Calcareous shales with ammonite and bivalve mould. H. Thalassinoides isp. in calcareous facies. 

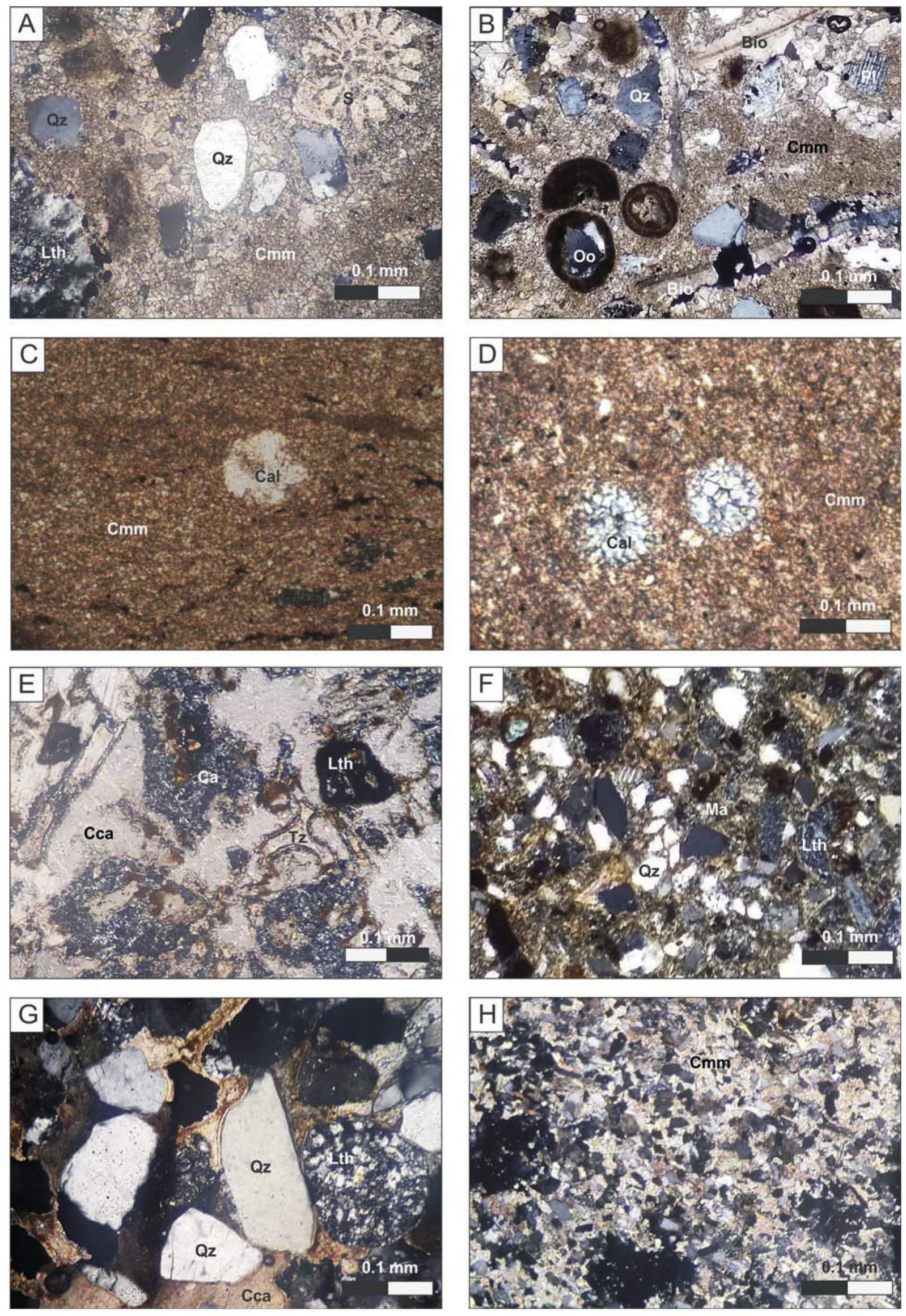

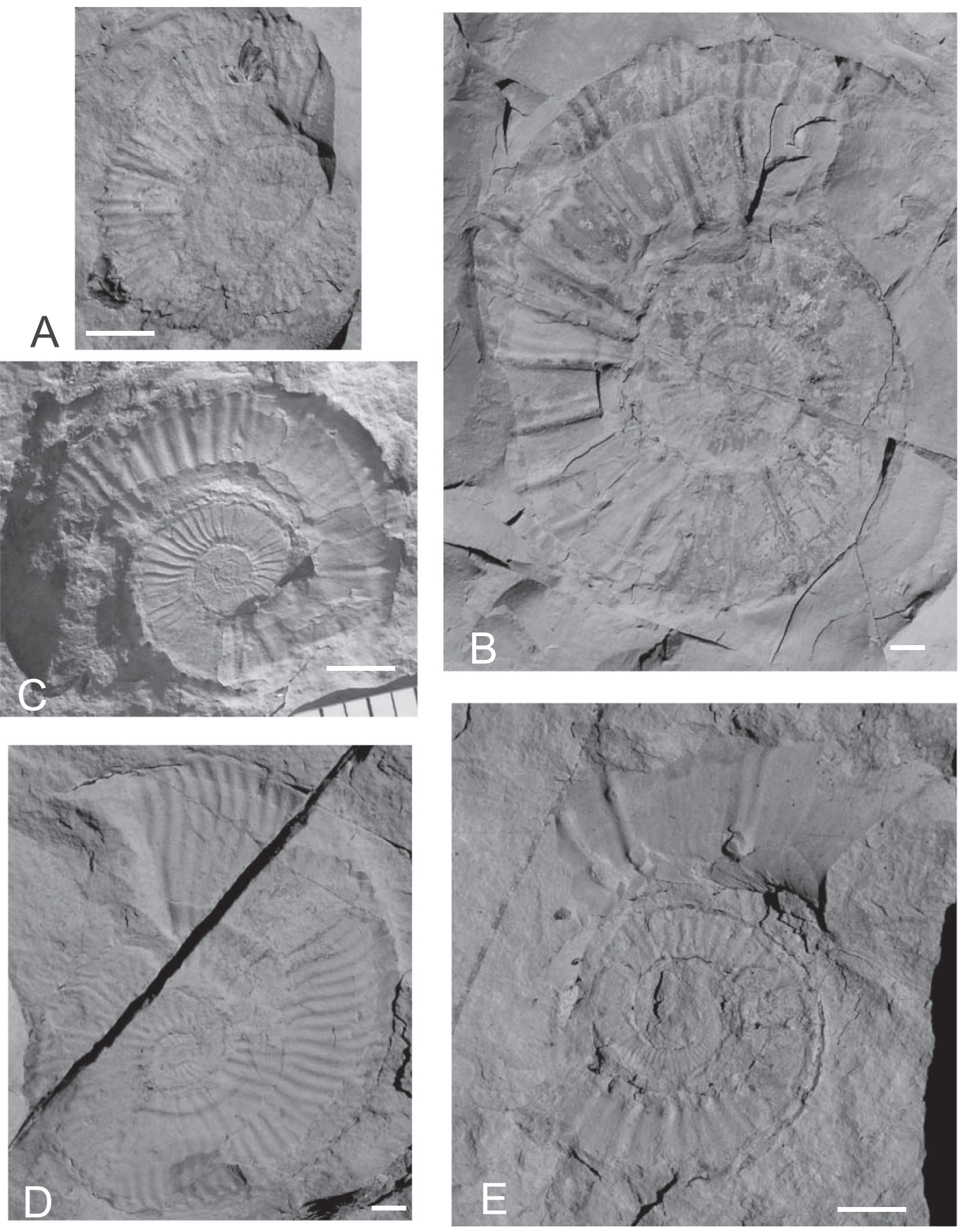

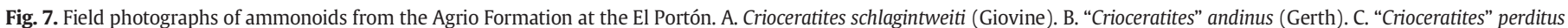
(Gerth). D. Decliveites agrioensis Aguirre-Urreta and Rawson. E. Crioceratites sp. Scale bar is $1 \mathrm{~cm}$.

4.2.2.1. FO of Eiffellithus striatus. The base of the CC4A nannofosil subzone is defined by the first occurrence (FO) of Eiffellithus striatus (Applegate and Bergen, 1988). Particularly in the El Portón section, this event is recorded in sample BAFC-NP 3995 in the middle part of the $P$. angulatiformis Subzone. In the Tethyan Realm, the boundary between
CC3B and CC4A is dated as late Valanginian (Applegate and Bergen, 1988; Bergen, 1994; Gardin et al., 2000).

E. striatus is a consistent global marker which has been recorded in several sections of the Neuquén Basin (Bown and Concheyro, 2004; Aguirre-Urreta et al., 2005; Concheyro et al., 2009; Lescano and

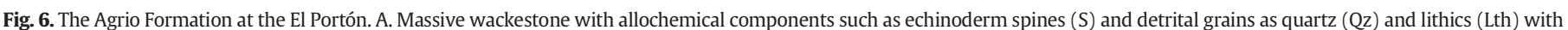

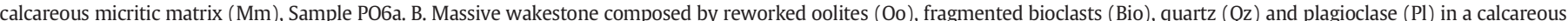

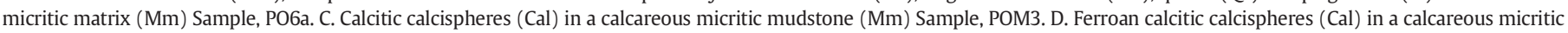

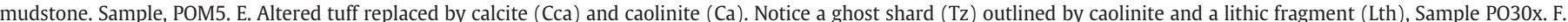



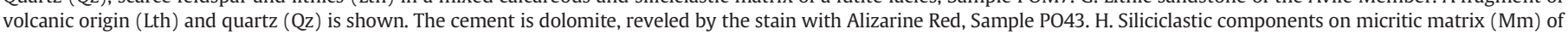
the calcareous shale facies, Sample PO4. 
Pommerol section

Number of ammonoids:

$\begin{array}{lll} & 1 & 9-13 \\ . & 2-4 & 14-19\end{array}$

- 5-8 20 and more

La Charce section

after Reboulet (1996)

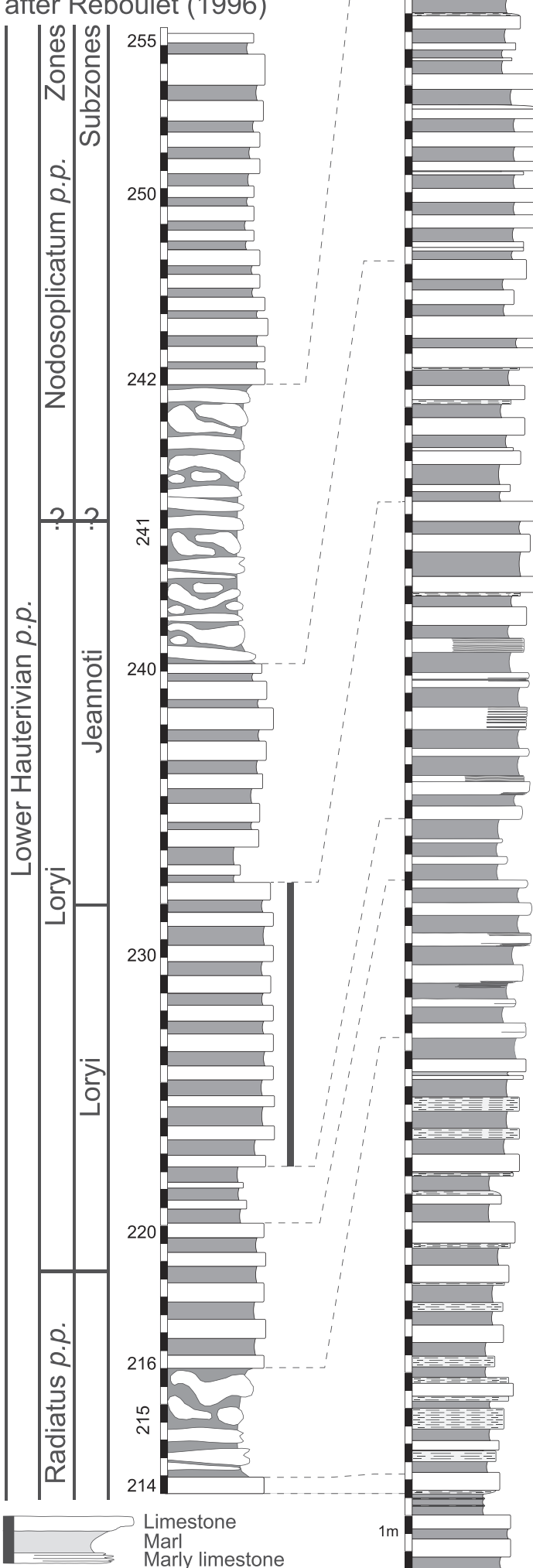

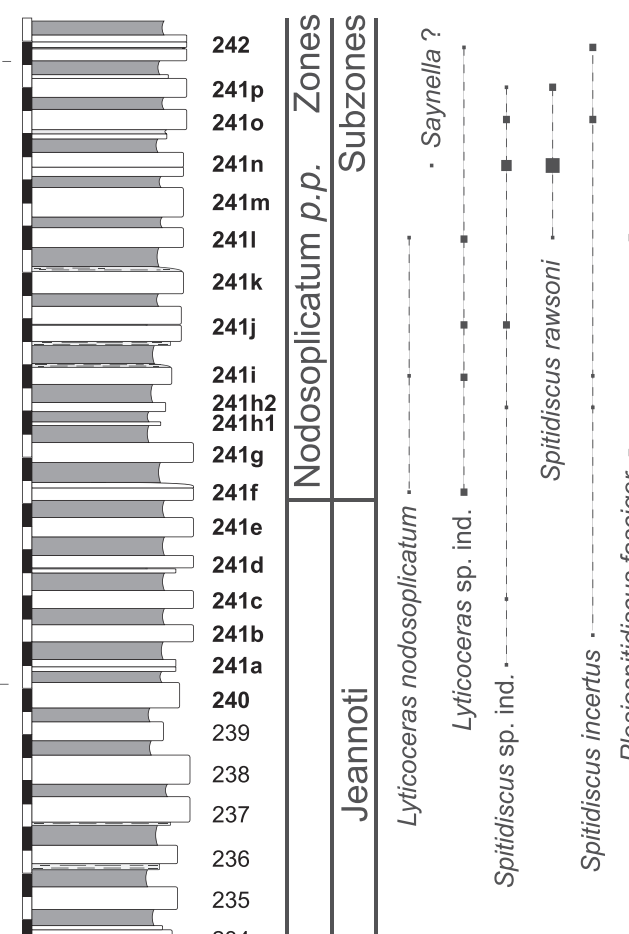

ำ

231

230

229
228

227
226

226
225

224

223

221

219

218

217

216b

$215 \mathrm{~m}$

$215 \mathrm{I}$

$215 \mathrm{k}$

215j

$215 \mathrm{~h}$

215g

$215 f$

$215 \mathrm{e} \simeq$

215d

$215 \mathrm{c}$

215b

215a

214

213b

213a 

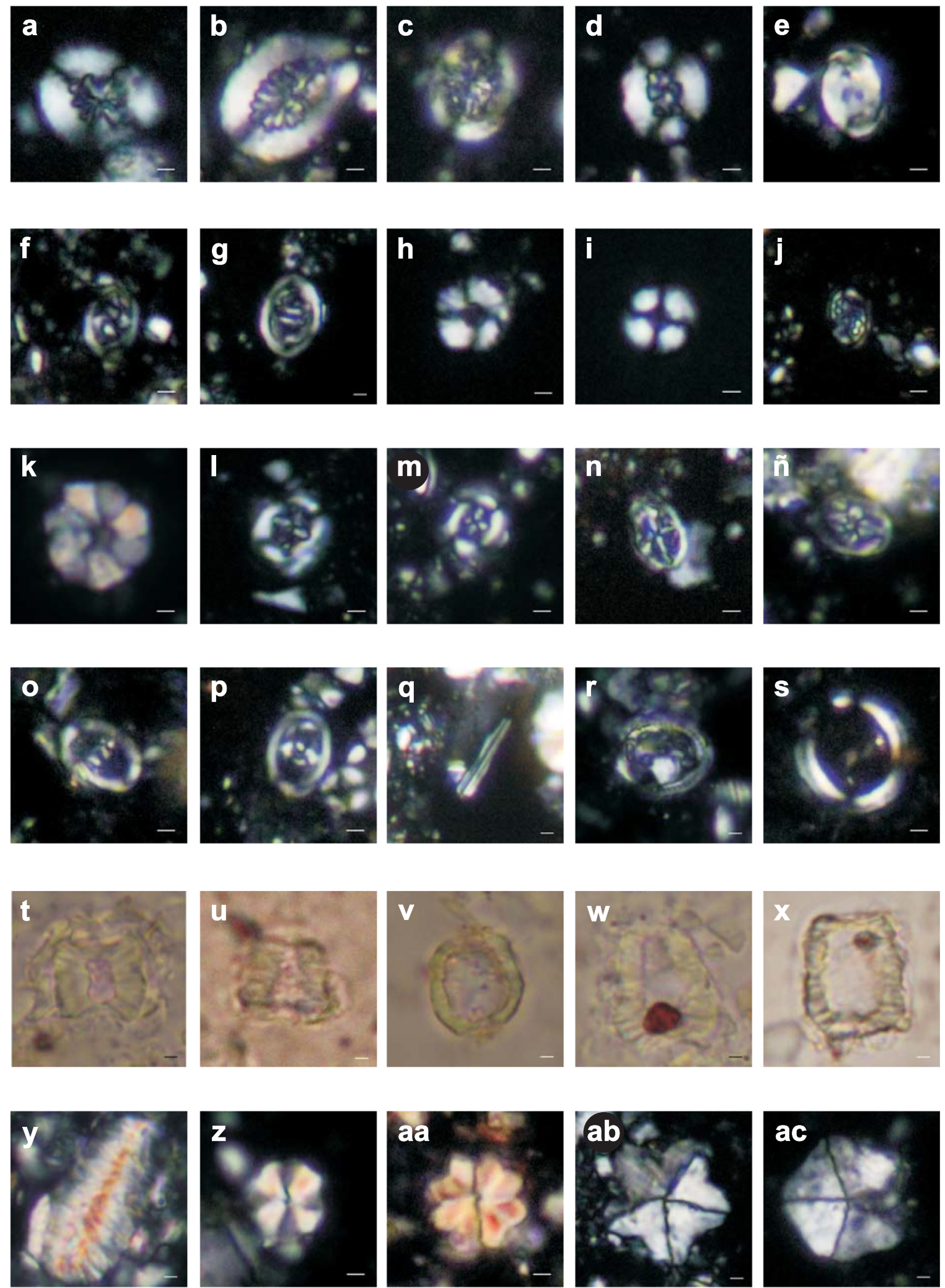

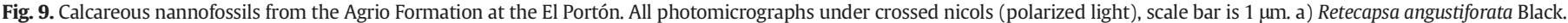



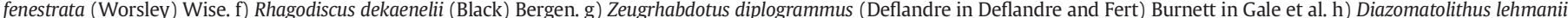

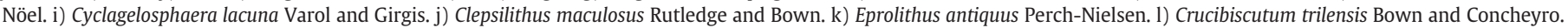

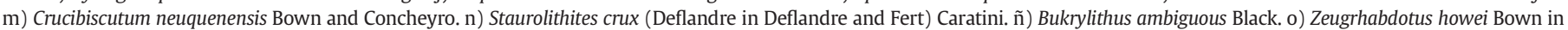

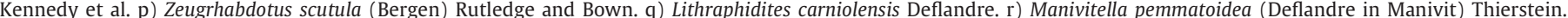

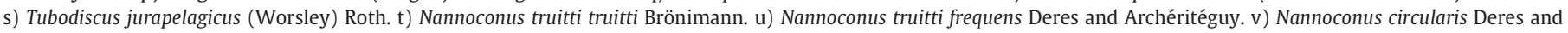

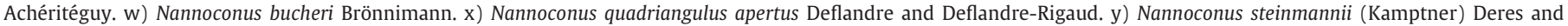
Achéritéguy. z-aa). Nannoconus ligius Applegate and Bergen. ab) Micrantholithus obtusus Stradner. ac) Micrantholithus hoschulzii (Reinhardt) Thierstein. 
Concheyro, 2009, 2014). It has been found in several Mediterranean (France, Poland, Czech Republic) and Boreal (United Kingdom, The Netherlands) sections and in oceanic boreholes at site 534 (Black Bahama Basin), 603 (North American margin) and 638 (Galicia margin), allowing valuable correlations (e.g. Black, 1971; Roth, 1983; Covington and Wise, 1987; Jakubowski, 1987; Bergen, 1994; Jeremiah, 2001; Morales et al., 2015).

The FO of E. striatus also indicates a Boreal bioevent and it has been correlated with the NLK17 (Jakubowski, 1987) and BC5 (Bown, 1998) nannofossil zones of the late Valanginian. In biostratigraphic schemes of the North Sea Basin, the FO of E. striatus has been used to define the base of LK27B subzone (Jeremiah, 2001) and recently this bioevent has also been identified in North-East Greenland (Pauly et al., 2012). In recent versions of the Geological Time Scale, the FO of E. striatus has been correlated with the base of the Criosarasinella furcillata Zone of the Mediterranean region and was calibrated with Polarity Chron CM10N (Ogg and Hinnov, 2012). Its FO is established at about the base of the $P$. angulatiformis Zone in Argentina supporting the ammonite correlation. However, in the Angles section in France, this bioevent has been recorded in the upper part of the Olcostephanus (O.) nicklesi Subzone, Neocomites peregrinus Zone (Duchamp-Alphonse et al., 2007).

4.2.2.2. LO of Eiffellithus windii. Eiffellithus windii is another consistent marker for several Tethyan and Boreal sections and oceanic boreholes (e.g. Applegate and Bergen, 1988; Bergen, 1994; Bown, 1998). Its LO has been used as a bioevent for the lower Hauterivian. In the Vocontian Basin, it occurs in the A. radiatus Zone (Bergen, 1994). In Boreal sections (Bown, 1998), this bioevent has been recorded in the upper part of the Endemoceras regale Zone, which correlates with the Tethyan C. loryi Zone (Reboulet et al., 2014).

In the El Portón section, the $\mathrm{LO}$ of $E$. windii coincides with the first sample (BAFC-NP 4018) assigned to the H. agrioensis Subzone, only $2.43 \mathrm{~m}$ above the dated tuff of $130.39 \pm 0.16 \mathrm{Ma}$ (Aguirre-Urreta et al., 2017). In the La Charce section, the last occurrence of $E$. windii occurs in the upper part of the A. radiatus Zone, in layer LCH 213 that corresponds to the bed 270 (Gardin, 2008). However, bed LCH 213 is located just below a slumped interval which corresponds to 14 marllimestone couplets in Pommerol (Fig. 8) and other sections near La Charce.

The LO of E. windii is considered a secondary bioevent within the CC4-A nannofossils subzone (Bergen, 1994). In the Neuquén Basin, this bioevent has been identified in several sections and correlated with the $H$. neuquensis Zone (Aguirre-Urreta et al., 2005; Concheyro et al., 2009) and at El Portón it occurs at the base of the H. agrioensis Subzone (H. neuquensis Zone). This supports the correlation of the base of $H$. agrioensis Subzone with the uppermost part of the A. radiatus Zone of the Mediterranean region.

4.2.2.3. LO of Eiffellithus striatus. The LO of Eiffellithus striatus is recorded in sample BAFC-NP 4042 in the basal levels of the Agua de la Mula Member within the $S$. riccardii Zone.

The LO of E. striatus also represents a consistent Tethyan bioevent, marking the early/late Hauterivian boundary in SE France and correlates with the lowermost upper Hauterivian S. sayni Zone (Bergen, 1994; Bown, 1998; Gardin et al., 2000; Kessels et al., 2006). The LO of E. striatus in the Boreal Realm, North Sea Basin and North-East Greenland occurs in the Milanowskia speetonensis Zone (Jeremiah, 2001; Pauly et al., 2012), which correlates with the upper part of the S. sayni Zone and the lower part of the S. ligatus Zone in the Tethys (Reboulet et al., 2014).

4.2.2.4. FO of Lithraphidites bollii. The FO of Lithraphidites bollii can be used as a marker to differentiate the CC4A and CC4B subzones (Applegate and Bergen, 1988). L. bollii, a consistent marker, has also been found in several Mediterranean sections (France, Italy, Spain and Switzerland) and oceanic boreholes at site 1 and 534 (Black Bahama
Basin), allowing valuable correlations (Thierstein, 1971, 1973; Cecca et al., 1994; Sprovieri et al., 2006; Aguado et al., 2014; among others).

The base of CC4B has been considered early Hauterivian in the Tethyan Realm and has been correlated with the C. loryi Zone (Bergen, 1994) and with Polarity Chron CM9 (Ogg and Hinnov, 2012). However, in several sections of the Neuquén Basin, the FO of $L$. bollii has been recognized at the base of the late Hauterivian (Aguirre-Urreta et al., 2005).

In the El Portón section the FO of $L$. bollii and the $\mathrm{LO}$ of $C$. cuvillieri (BAFC-NP 4043) have been found together in basal levels with C. schlagintweiti in the Agua de la Mula Member.

4.2.2.5. LO of Cruciellipsis cuvillieri. The LO of Cruciellipsis cuvillieri has been used as a global marker for the early-late Hauterivian boundary (Bralower et al., 1995; Mutterlose et al., 1996; Ogg et al., 2004). In the Tethyan Realm, this bioevent is associated with the LO of E. striatus (Ogg et al., 2008) in the middle part of the S. sayni Zone (Thierstein, 1973; Bergen, 1994) close to the base of Chron CM8r in Italy (Channell et al., 1995). As the S. sayni Zone has not been recognized in the Boreal Realm, the LO of $C$. cuvillieri has proved to be an important link between both realms. However, in the Boreal Realm both bioevents (LO of C. cuvillieri and LO de E. striatus) occur in the late Hauterivian (Bown, 1998).

In El Portón, the LO of C. cuvillieri is registered at the base of the C. schlagintweitii Zone in the sample BAFC-NP 4043 which indicates an early late Hauterivian age.

4.2.2.6. FO of Nannoconus ligius. Nannoconus ligius is a consistent marker in several Tethyan sections (Applegate and Bergen, 1988). The FO of $N$. ligius is considered a secondary bioevent within the CC4B nannofossil subzone. According to Bown and Concheyro (2004), the FO of N. ligius in the Neuquén Basin is a bioevent of the late Hauterivian.

In the study section of El Portón, the FO of $N$. ligius (BAFC-NP 4060) has been recorded in the middle part to $C$. diamantensis Zone and in the SE of France this bioevent has been correlated with the P. ligatus Zone (Bergen, 1994).

In the Tethyan Realm the boundary between CC4B and CC5 is characterized by the last occurrence (LO) of Speetonia colligata though this event has not been observed yet in the Neuquén Basin. Upwards in the section of El Portón, the LOs of C. maculosus, L. bollii and N. ligius have been recorded and correlated to the CC5 Zone.

4.2.2.7. LO of Clepsilithus maculosus. In the nannofossil zonal schemes proposed for the Boreal Realm, the LO of Clepsilithus maculosus defines the boundary between $\mathrm{BC} 11$ and $\mathrm{BC} 12$ zones of late Hauterivian age. This event was correlated with the Simbirskites variabilis Subzone comprising the Hauterivian-Barremian boundary (Bown, 1998; Jeremiah, 2001). In El Portón the LO of C. maculosus (BAFC-NP 4089) is recorded within the $P$. groeberi Zone assigned to the late Hauterivian.

4.2.2.8. LO of Lithraphidites bollii. The LO of Lithraphidites bollii has been used as a reliable marker within the CC5 Zone. In the Tethyan region (France, Italy, Spain), it occurs at the top of the Hauterivian within the P. ohmi Zone, and within the Polarity Chron CM5 (Aguado et al., 2014; Bergen, 1994; Bralower, 1987; Channell et al., 1987; Channell and Erba, 1992; Ogg and Hinnov, 2012; Reboulet et al., 2014).

In the El Portón section, the LO of L. bollii (BAFC-NP 4093) has been recorded and correlated to the CC5 Zone. In the Neuquén Basin, this bioevent is recorded higher in the Agua de la Mula Member of the Agrio Formation, in beds included in the P. groeberi Zone, which is here correlated with part of the B. balearis Zone.

\subsection{Astrochronology}

\subsubsection{Pilmatué Member}

The long-term trend of the MS series shows a gradual increase in the MS values. It first shows an overall decrease of the MS values from 4 to $2 * 10^{-3} \mathrm{~kg}^{-1}$ throughout the P. angulatiformis Zone (Fig. 10.B). This 


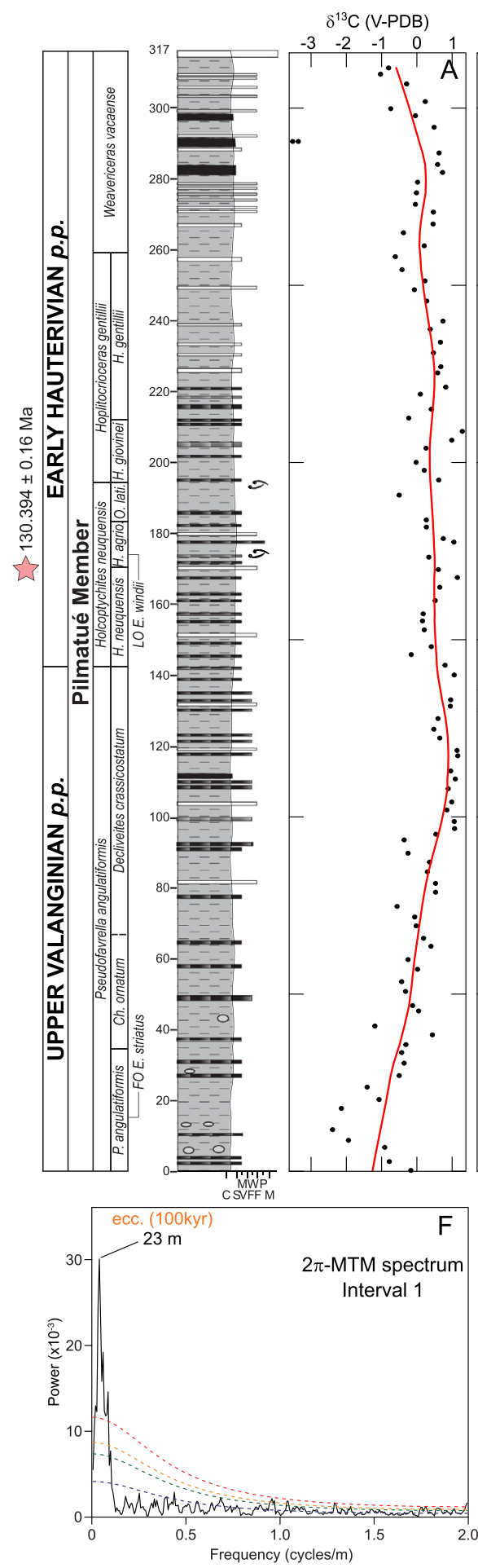

MS $\left(\times 10^{-3} \mathrm{~kg}^{-1}\right) \quad$ Standardised MS

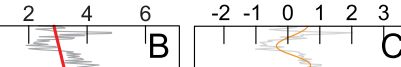

Frequency (cycles. $\mathrm{m}^{-1}$ ) Frequency (cycles. $\mathrm{m}^{-1}$ )<smiles>[18O][18O][18O][18O]</smiles>

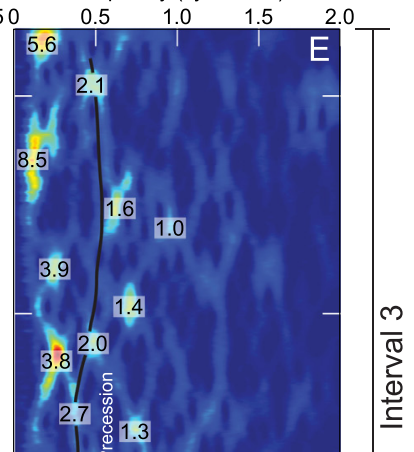

e22

e21

e20

e19

e18

e17

I 1 D

\begin{tabular}{l}
$e 17$ \\
$e 15$ \\
$e 14$ \\
$e 14$ \\
\hline
\end{tabular}

\begin{aligned} \hline$e 13 \\$ e13 \\ e1t \\ el1 \\ \hline\end{aligned}

\begin{tabular}{|l|l|l}
\hline e12 \\
et1 \\
e10 \\
\hline e9 \\
\hline
\end{tabular}

e8

:

=

$\sum$



$\sum$

e7

8

27

26

e25

24

23

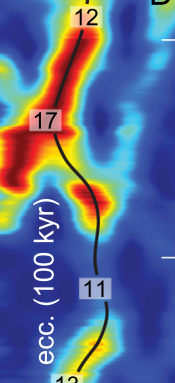

${ }_{13}$

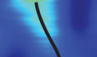

-

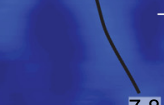

$\begin{array}{rl}4.1 & 1.0 \\ +\quad 2.6 & \\ 1.5 & \end{array}$

7.8

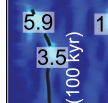

16

0.6

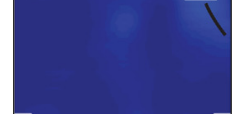

0.9

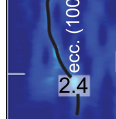

1.3 .1 .1$.

. $^{1.1 .0}$

$\frac{\sqrt{\pi}}{\frac{\pi}{2}}$
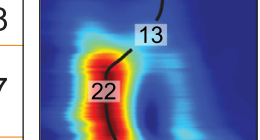

e6
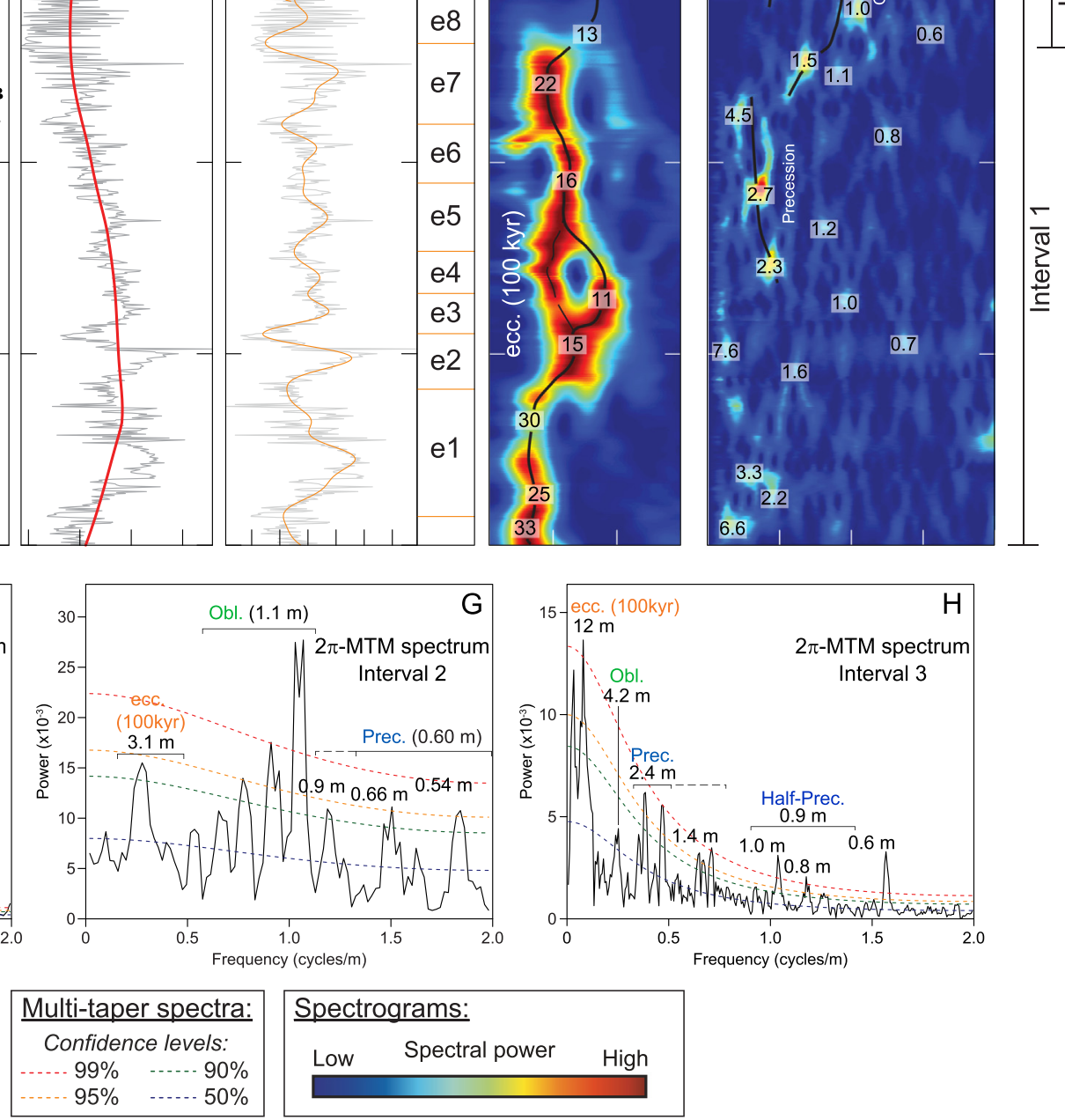

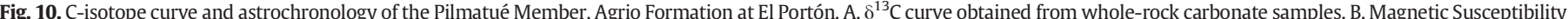

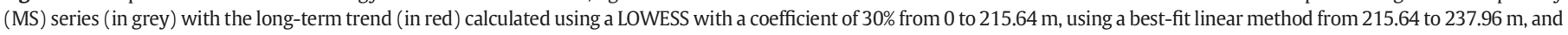

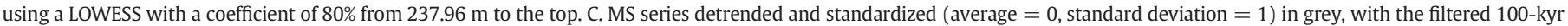

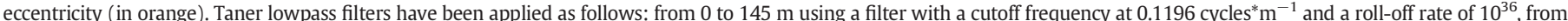

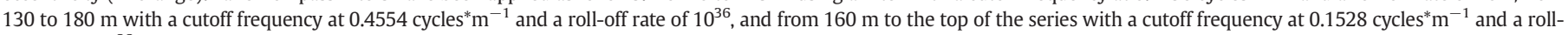

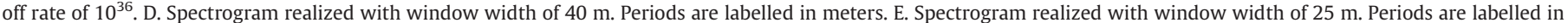
meters. F., G. and H. 2ா-MTM spectra respectively realized on Interval 1, 2 and 3. 


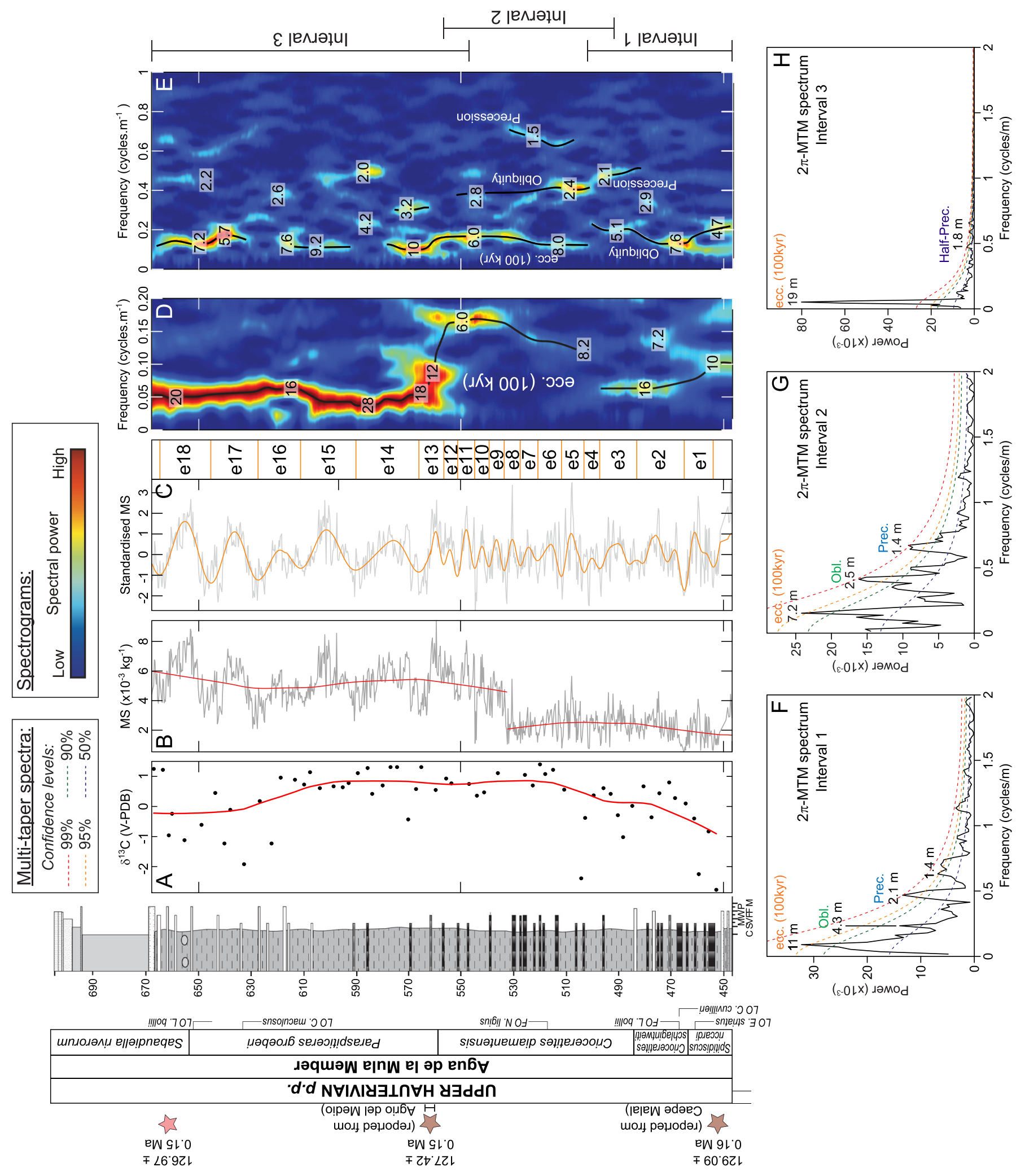


decrease reflects the progressive enrichment in carbonates throughout the ammonoid zone. Then, values show an overall increase to $4.7^{*} 10^{-3} \mathrm{~kg}^{-1}$ linked to a return to much siliciclastic sedimentation. This trend is interrupted by rapid decrease in MS values from 215 to $237 \mathrm{~m}$, where an interval of alternating marl and limestone beds crops out. Then MS values decrease on average to $3^{*} 10^{-3} \mathrm{~kg}^{-1}$. The trend shows a strong link between the MS and the lithology, the MS values reflecting the ratio between carbonate vs. detrital components. The long-term trend of the series was eliminated using a LOWESS method (LOcally WEighted Scatterplot Smoothing; Cleveland, 1979) calculated over $30 \%$ of the dataset from the base of the series to $215 \mathrm{~m}$, a best-fit linear smoothing from $215 \mathrm{~m}$ to $237 \mathrm{~m}$, and a LOWESS calculated over $80 \%$ of the dataset from $237 \mathrm{~m}$ to the top of the Pilmatué Member. The choice of the coefficient is selected so that it represents $\sim 60 \mathrm{~m}$ of the dataset, which efficiently removes the power of the spectrum near frequency 0 , while preserving powers at higher frequencies and not creating spurious spectral peaks in the very low frequencies. The LOWESS method has also the advantage of preserving the phasing between the original and the residual datasets.

The spectrogram performed on 40-m windows (Fig. 10.D) reveals a high-power period of $33 \mathrm{~m}$ at the base of the section decreasing to $13 \mathrm{~m}$ at $140 \mathrm{~m}$. After an interval where no period is observed at low frequencies, from 140 to $170 \mathrm{~m}$, a period appears at $7.8 \mathrm{~m}$ and increases in power and period to $12 \mathrm{~m}$ at the top of the section. The spectrogram performed on 20-m windows reveals high-powers between levels 70 and $115 \mathrm{~m}$, with periods ranging from 2.3 to $4.5 \mathrm{~m}$ (Fig. 10.E). Periods decrease from 1.5 to $1.1 \mathrm{~m}$, from levels $115 \mathrm{~m}$ to $160 \mathrm{~m}$. From 140 to $180 \mathrm{~m}$, another period appears increasing from $2.4 \mathrm{~m}$ to $5.9 \mathrm{~m}$. From $180 \mathrm{~m}$ to the top of the series, a period increases from $1.5 \mathrm{~m}$ to $2.1 \mathrm{~m}$.

The spectrogram performed on 40-m width windows shows three intervals from the base to $140 \mathrm{~m}$, from $140 \mathrm{~m}$ to $170 \mathrm{~m}$, and from $170 \mathrm{~m}$ to the top of the series. A $2 \pi-\mathrm{MTM}$ spectrum was calculated on each of these intervals. On Interval 1, the spectrum reveals a highpower peak with a mean period of $23 \mathrm{~m}$ (Fig. 10.F). On Interval 2, periods appear at $3.1 \mathrm{~m}, 1.1 \mathrm{~m}$ and $0.6 \mathrm{~m}$ (Fig. 10.G). On Interval 3, periods appear at $12 \mathrm{~m}, 2.4 \mathrm{~m}, 1.4 \mathrm{~m}, 0.9 \mathrm{~m}$ and $0.6 \mathrm{~m}$ (Fig. 10.H).

\subsubsection{Agua de la Mula Member}

The long-term trend of the MS series shows a rapid increase of the values at $\sim 95 \mathrm{~m}$ from $2^{*} 10^{-3} \mathrm{~kg}^{-1}$ to $5^{*} 10^{-3} \mathrm{~kg}^{-1}$, while the sediment evolves from marl-limestone alternations to uniform marl (Fig. 11.B). The long-term trend of the series was eliminated using a LOWESS calculated over $50 \%$ of the datasets from 447 to $553 \mathrm{~m}$ and from $553 \mathrm{~m}$ to the top of the series.

The spectrograms display from the base of the series to $500 \mathrm{~m}$ two periods evolving from 10 to $16 \mathrm{~m}$ and from $4.7 \mathrm{~m}$ to $7.6 \mathrm{~m}$ (Fig. 11.D and $\mathrm{E}$ ). The $2 \pi-M T M$ spectrum of Interval 1 (Fig. 11.F) displays three periods at $11 \mathrm{~m}, 4.3 \mathrm{~m}$ and $2.1 \mathrm{~m}$. From 500 to $560 \mathrm{~m}$, the main periods observed on the spectrograms are from 8.2 to $6.0 \mathrm{~m}$ (Fig. 11.D), 2.4 to $2.8 \mathrm{~m}$, and around $1.5 \mathrm{~m}$ (Fig. 11.E). The $2 \pi-\mathrm{MTM}$ spectrum displays the same periods (Fig. 11.G). From $560 \mathrm{~m}$ to the top of the series, the spectrograms display a high-power period evolving from 16 to $28 \mathrm{~m}$ (Fig. 11.D), and a period evolving from 5.7 to $9.2 \mathrm{~m}$ (Fig. 11.E). The $2 \pi-\mathrm{MTM}$ spectrum realized on this interval shows a high-power period at $19 \mathrm{~m}$ (Fig. 11.H).

\subsubsection{The La Charce-Pommerol section}

The astrochronology of the La Charce-Pommerol section based on the gamma-ray spectrometry (GRS) signal was first performed in Martinez et al. (2015) and here the results previously obtained are outlined. The GRS signal ranges from $3.2 \mathrm{ppm}$ eU (equivalent Uranium) to $15.6 \mathrm{ppm}$ $\mathrm{eU}$, with an average value of $8.6 \mathrm{ppm}$ eU (Fig. 12). The series displays a broad trend to lower values due to progressive enrichment in $\mathrm{CaCO}_{3}$ of the marl-limestone alternations. The trend is interrupted at 153.25 and $177.35 \mathrm{~m}$ by rapid increase in GRS, associated with clay-enriched alternations. The long-term trend of the series is thus removed using three bestfit linear regression between these two events of rapid increase in GRS.

The 40- $\mathrm{m}$ spectrogram performed on the detrended GRS series reveal a period around $20 \mathrm{~m}$ appearing from the base of the series to $115 \mathrm{~m}$ and sporadically appearing from $200 \mathrm{~m}$ to the top of the series (Fig. 12.C). From the base of the series to $115 \mathrm{~m}$, the period first decreases from 28 to $11 \mathrm{~m}$ at $\sim 30 \mathrm{~m}$. It slightly increases to $14 \mathrm{~m}$ at level $70 \mathrm{~m}$, before sharply increasing to $23 \mathrm{~m}$ at level $80 \mathrm{~m}$. This period then remains roughly stable to level $115 \mathrm{~m}$.

The 10-m spectrogram indicates a period evolving around $1 \mathrm{~m}$ throughout the entire section and corresponding to the marllimestone alternation (Fig. 12.D). From levels 0 to $20 \mathrm{~m}$, the period has average values $0.9 \mathrm{~m}$. From levels 20 to $80 \mathrm{~m}$, the period reaches a maximum value of $1.2 \mathrm{~m}$. Then the period decreases to $0.8 \mathrm{~m}$ at $110 \mathrm{~m}$ and fluctuates around this mean value of $0.8 \mathrm{~m}$ to the top of the series, with periods ranging from 1.0 to $0.6 \mathrm{~m}$.

\subsubsection{The Río Argos section}

The astrochronology of the Río Argos section based on the gamma-ray spectrometry (GRS), magnetic susceptibility and clay mineral signals was performed by Martinez et al. (2012, 2015) and Moiroud et al. (2012). We here outline the results previously obtained. The GRS signal ranges from 3.7 to $16.3 \mathrm{ppm}$ eU, with an average value of $8.6 \mathrm{ppm}$ eU (Fig. 13.A). The GRS values remain stable in the lowermost $50 \mathrm{~m}$ of the series around a mean value of $8.5 \mathrm{ppm}$ eU. They increase from 50 to $80 \mathrm{~m}$ to mean values around $10 \mathrm{ppm}$ eU. The GRS values then slightly decrease to mean values around $9 \mathrm{ppm}$ eU toward level $150 \mathrm{~m}$ before decreasing more rapidly to mean values of $8 \mathrm{ppm}$ eU toward the top of the series. The long-term trend of the series was removed using a LOWESS calculated over $20 \%$ of the series.

The 40- $\mathrm{m}$ spectrogram performed on the detrended GRS series reveal a period evolving from $5.7 \mathrm{~m}$ to $4.2 \mathrm{~m}$ from the base of the series to level $80 \mathrm{~m}$ (Fig. 13.C). The period continues from 105 to the top of the series, evolving from 3.7 to $2.9 \mathrm{~m}$ to the top of the series. At lower frequencies, a period of $17 \mathrm{~m}$ is expressed between levels 90 and $115 \mathrm{~m}$ and turns to a period of $26 \mathrm{~m}$ between levels 125 and $150 \mathrm{~m}$.

The 10-m spectrogram reveals a band of period continuously expressed throughout the series, starting with a period of $1.2 \mathrm{~m}$ from the base of the series to $60 \mathrm{~m}$ (Fig. 13.D). The period of this band then progressively decreases to $0.6 \mathrm{~m}$ at $133 \mathrm{~m}$. It then fluctuates between 0.6 and $0.8 \mathrm{~m}$ in the last $20 \mathrm{~m}$ of the series. At lower frequencies, the period evolving from $5.7 \mathrm{~m}$ to $2.9 \mathrm{~m}$ observed in the $40-\mathrm{m}$ spectrogram is also observed in the $10-\mathrm{m}$ spectrogram.

\subsection{Geochronology of the El Portón section}

Ten tuff samples were collected along the Agrio Formation at El Portón, but only two: POT 3 (Aguirre-Urreta et al., 2017) and EP 1711-1712 (this study) were suitable for $\mathrm{U}-\mathrm{Pb}$ dating. The other eight were discarded either because they lacked zircons, or the zircons were clearly detrital. A sample with abundant and relatively large (approximately $100-300 \mu \mathrm{m}$ in long dimension), mostly equant, prismatic zircon

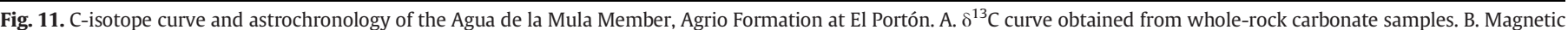

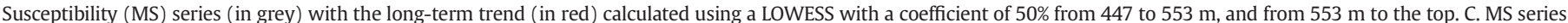

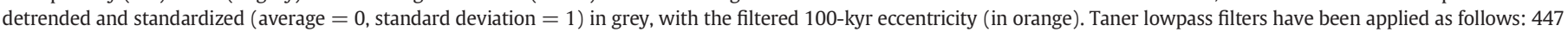

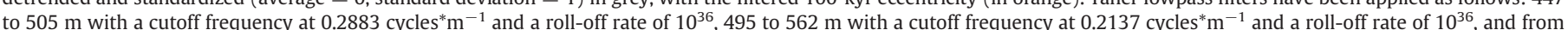

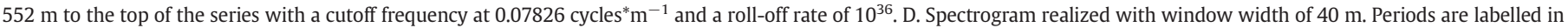

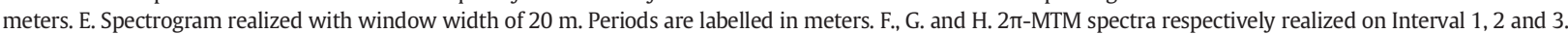




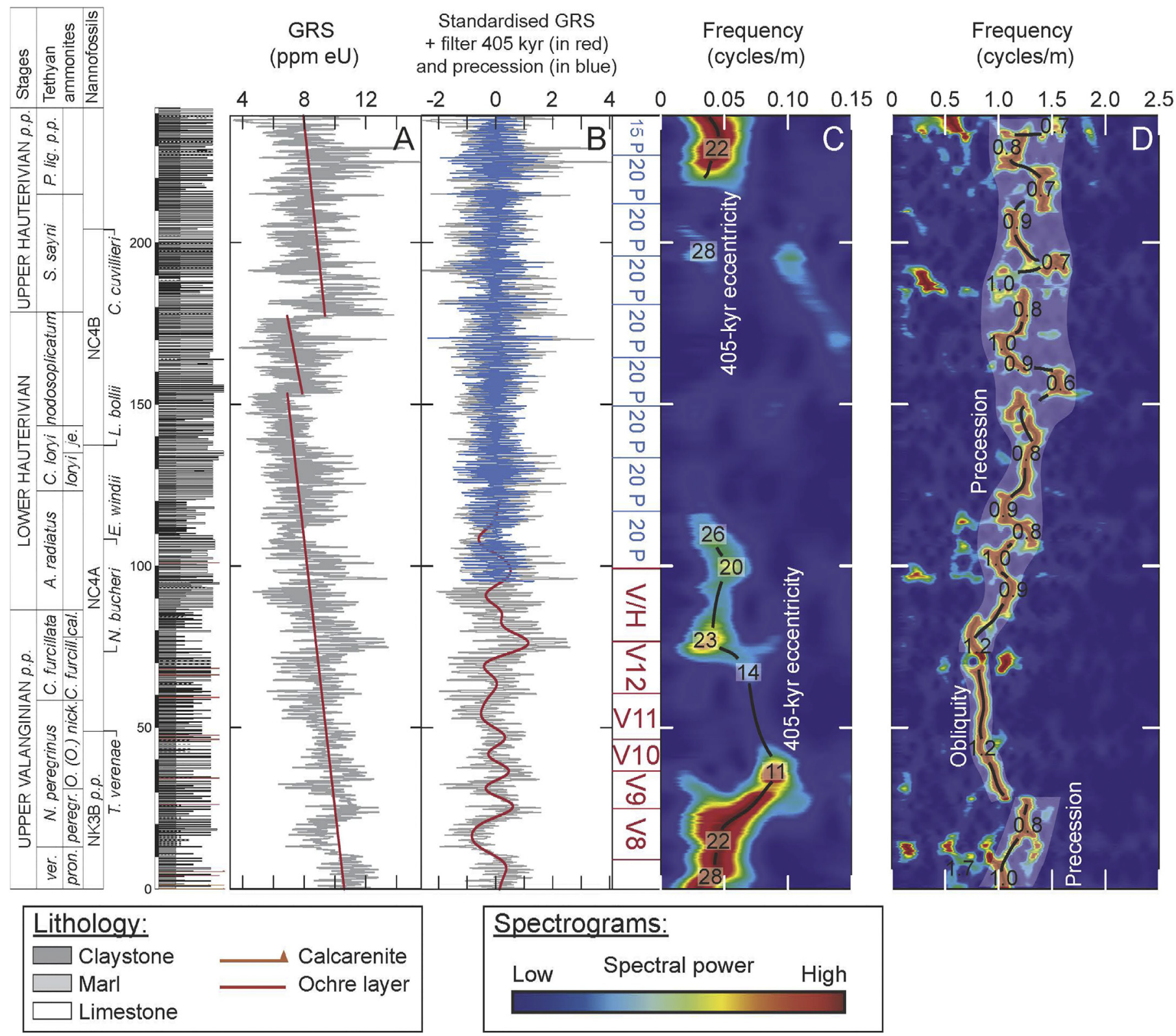

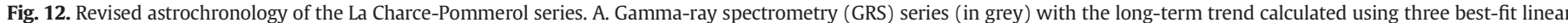

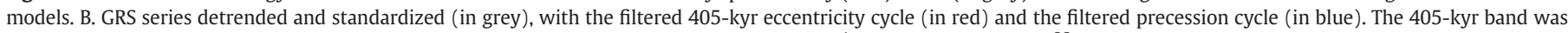

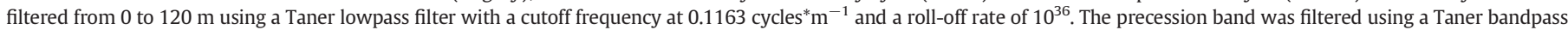

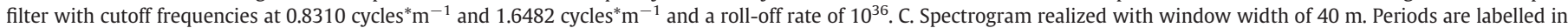

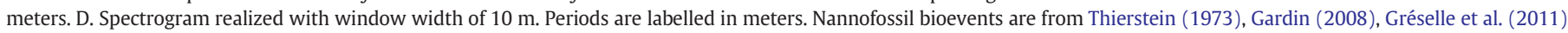
and Barbarin et al. (2012).

crystals was separated from a hand sample of tuff EP 1711-1712. CLimaging of over 200 zircon crystals and crystal fragments revealed a consistent population of brightly luminescent, oscillatory zoned zircon with occasional non-luminescent cores (Fig. 14). Fifty-seven spot analyses by LA-ICPMS yielded consistently Early Cretaceous dates regardless of core or rim location. Six grains were selected for CA-ID-TIMS analysis on the basis of homogeneous CL pattern (avoiding non-luminescent cores) and LA-ICPMS results. Chemical abrasion in concentrated HF at $190{ }^{\circ} \mathrm{C}$ for $12 \mathrm{~h}$ resulted in only moderate dissolution of the zircon crystals. All six analyses are concordant and equivalent, with a weighted mean ${ }^{206} \mathrm{~Pb} /{ }^{238} \mathrm{U}$ date of $126.97 \pm 0.04(0.07)[0.15]$ Ma (MSWD $=0.91$ ), which is interpreted as dating the eruption and deposition of this tuff (Fig. 15 and Table 1).

\subsection{Carbon isotopes of the El Portón section}

In the Pilmatue Member, the $\delta^{13} \mathrm{C}$ values increase on average from -2 to $+1 \%$ from the bottom to level $115 \mathrm{~m}$ (Fig. 10.A). Then, values gently decrease to average values around $+0.2 \%$ o at $280 \mathrm{~m}$. From level $280 \mathrm{~m}$ to the top of the Pilmatue Member, the $\delta^{13} \mathrm{C}$ values rapidly decrease to $-1 \%$.

In the Agua de la Mula Member, the $\delta^{13} \mathrm{C}$ values rapidly increase on average from -1.8 to $+0.2 \%$ from the bottom of the member to level $475 \mathrm{~m}$ (Fig. 11.A). The values then increase gentler to mean values around $+1 \%$ at level $610 \mathrm{~m}$. $\delta^{13} \mathrm{C}$ values decrease to mean values of $-0.5 \%$ at $200 \mathrm{~m}$ before increasing to $+0.5 \%$ o to the top of the series. 

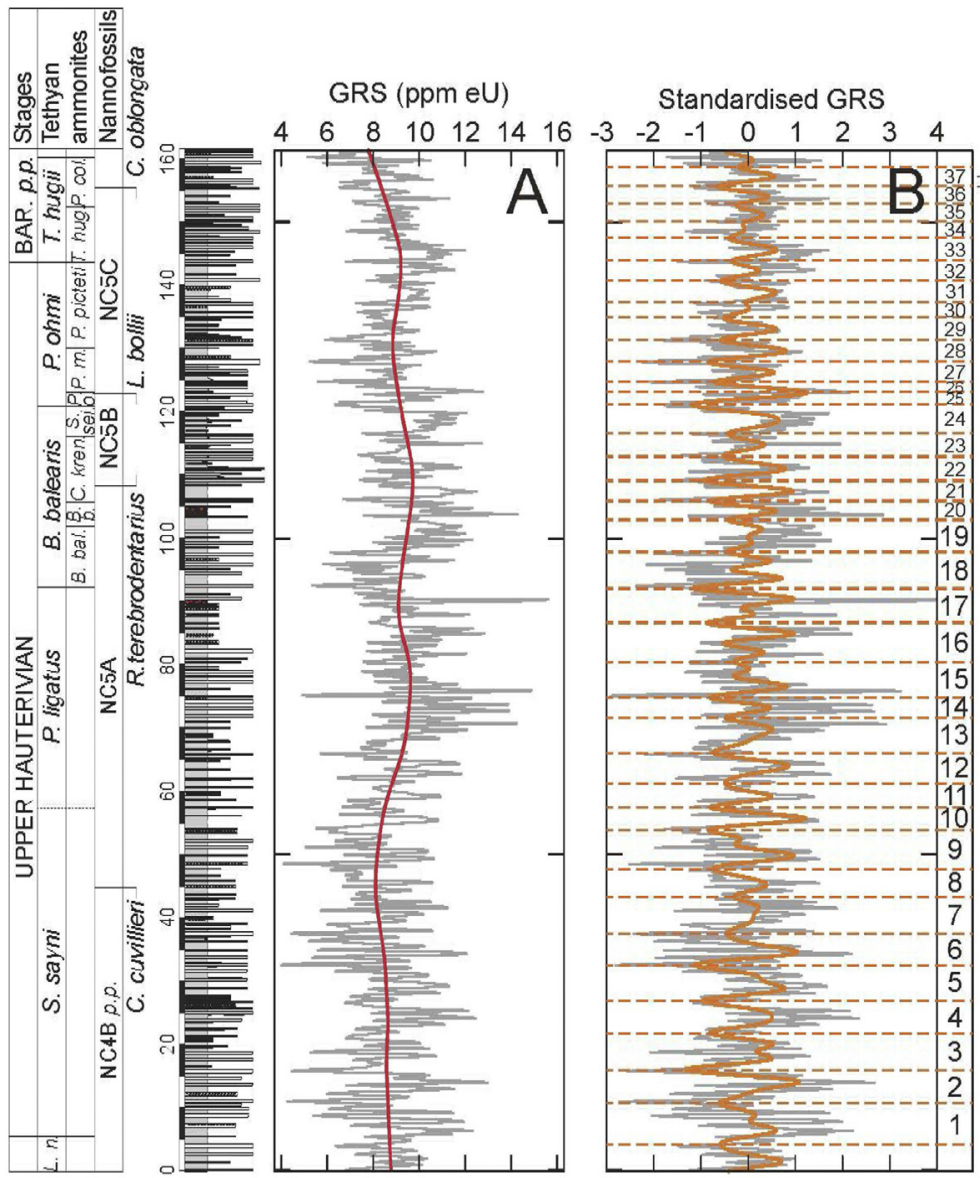

\section{Frequency (cycles $/ \mathrm{m})$}

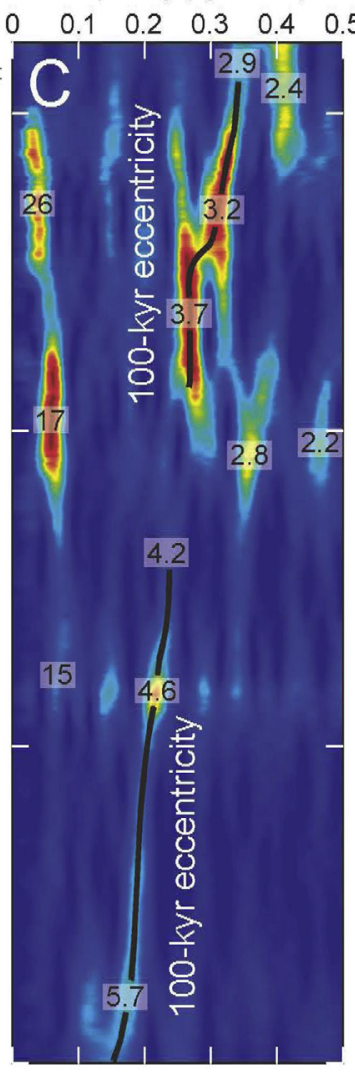

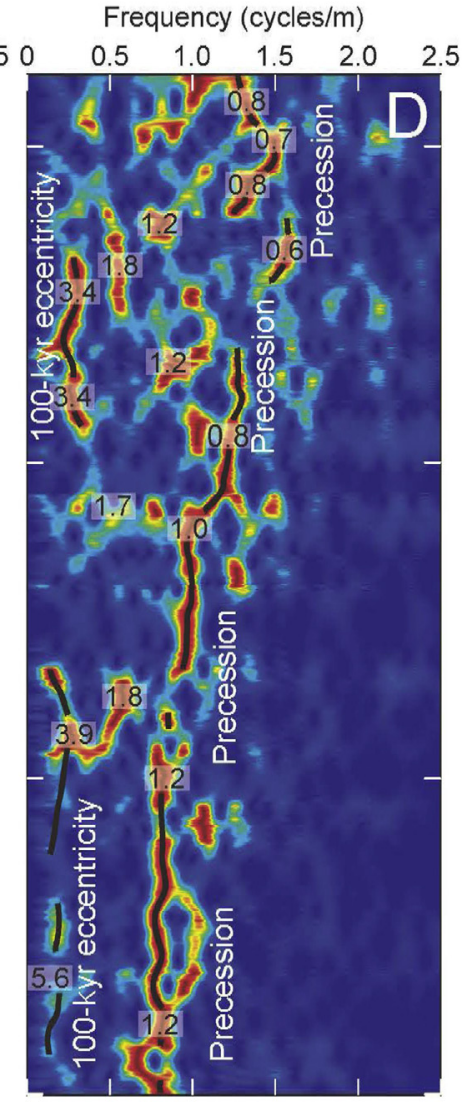

\section{Río Argos (Subbetic Domain)}

\begin{tabular}{|c|c|c|c|}
\hline Lithology: & Spe & ograms: & \\
\hline limestone & Low & Spectral power & High \\
\hline marl & & & \\
\hline
\end{tabular}

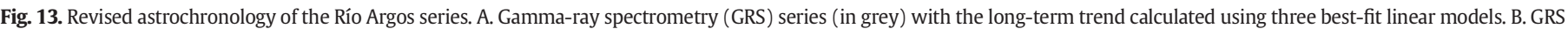

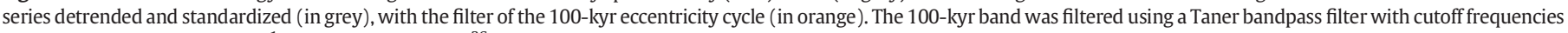

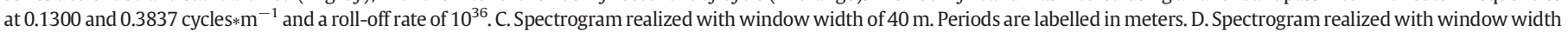
of $10 \mathrm{~m}$. Periods are labelled in meters. Nannofossil bioevents are from Company et al. (2005) and Aguado et al. (2014).

\section{Discussion}

\subsection{Astrochronology of the El Portón section}

Three intervals have been defined in the Pilmatué Member based on the spectral composition of the magnetic susceptibility (Fig. 10). The interval from 0 to $140 \mathrm{~m}$ displays a significant period at $23 \mathrm{~m}$ (Fig. 10.F). This interval covers the $P$. angulatiformis Andean zone, which corresponds to the Tethyan zone of $C$. furcillata, whose duration is 0.64 myr (Martinez et al., 2013). The basal part of the interval contains the first occurrence of $E$. striatus. In the Tethyan area, the duration between the FO of E. striatus and the base of the Hauterivian is assessed at $1.0 \mathrm{myr}$ (Martinez et al., 2013). Thus, depending on the biostratigraphic marker considered, the interval from 0 to $140 \mathrm{~m}$ in the Pilmatué Member of El Portón has a duration ranging from 0.64 to 1.0 myr, representing an average duration of 0.82 myr. The interval has a sedimentation varying from 140 to $219 \mathrm{~m} / \mathrm{myr}$, so that the cycle at $23 \mathrm{~m}$ has a duration ranging from 105 to $164 \mathrm{kyr}$. This duration falls in the range of the short eccentricity cycle (95-124 kyr). The cycle observed from 70 to $115 \mathrm{~m}$ with periods ranging from 3 to $5 \mathrm{~m}$ is thus assigned to the precession (Fig. 10.E).

The three cycles in Interval 2 in the Pilmatué Member at 3.1, 1.1 and $0.6 \mathrm{~m}$ show a period ratio of $1: 2.8: 5.2$, which fits with the period ratio between the 100-kyr eccentricity, the obliquity and the precession (Fig. 10.G). The cycles in Interval 3 of the Pilmatué Member at $12 \mathrm{~m}, 4.2 \mathrm{~m}$ and $2.4 \mathrm{~m}$ have ratios of $1: 2.9: 5$, which correspond to the 100-kyr eccentricity, the obliquity and the precession respectively (Fig. 10.H).

Interval 1 in the Agua de la Mula Member shows three cycles at $11 \mathrm{~m}, 4.3 \mathrm{~m}$ and $2.1 \mathrm{~m}$ (Fig. 11.F). The ratio between these periods at $1: 2.6: 5.3$ corresponds to the ratio between the $100-$ kyr eccentricity, the obliquity and the precession cycles, respectively. Interval 2 displays three periods at $7.2 \mathrm{~m}, 2.5 \mathrm{~m}$ and $1.4 \mathrm{~m}$, which respectively correspond to the 100-kyr eccentricity, the obliquity and the precession (Fig. 11.G). Interval 3 only displays a high-power peak at $18 \mathrm{~m}$ (Fig. 11.H). The upper part of the interval contains the tuff layer which provides the $\mathrm{U}$ $\mathrm{Pb}$ age dated here at $126.97 \pm 0.15 \mathrm{Ma}$ (Fig. 15). The base of the interval corresponds to the base of the P. groeberi Zone. Based on the ammonoid zonation and the lithostratigraphy, the location of the tuff layer, on which zircons provided a U-Pb age in the Agrio del Medio section (Aguirre-Urreta et al., 2015), was correlated to the El Portón section with a precision of $\pm 5 \mathrm{~m}$. The duration in between the isotopic ages is 0.45 myr. The cycle of $18 \mathrm{~m}$ shows five repetitions in this interval (Fig. 11.C), implying a mean duration of $90 \mathrm{kyr}$, which falls in the range of the 100-kyr eccentricity. 


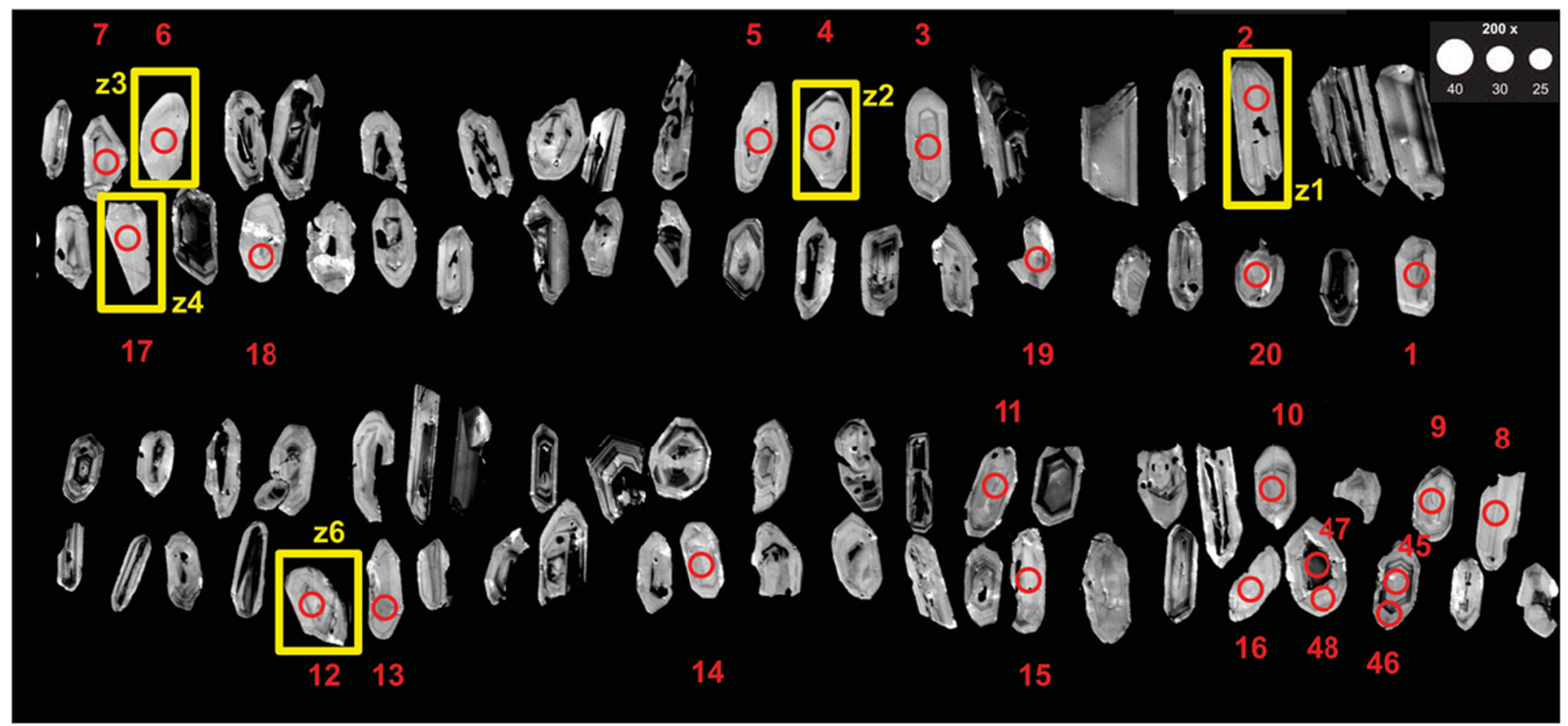


isotopic analysis are framed and numbered, each number coinciding with data in Table 1.

This eccentricity cycle is continuously recorded throughout the intervals analysed here and shows 47 repetitions. In the astronomical solutions (Laskar et al., 2004), the average duration of the short eccentricity calculated over 47 consecutive cycles in the last 20 myr is $95.6 \pm 2$ kyr. Assuming a constant duration of the short-eccentricity period, the total duration of the sediment recovered here is calculated at $4.60 \pm 0.09$ myr, including $2.83 \pm 0.06$ myr in the Pilmatué Member and $1.77 \pm 0.04$ myr in the Agua de la Mula Member.

The accuracy of this time scale also depends on the bounding of the short eccentricity cycles. Uncertainties still exist in the Pilmatué Member in the bounding of cycles e3-e4, in which the spectrogram shows a node in the record of the eccentricity cycles (Fig. 10.E), within cycle e17, where the MS signal may split this cycle into two sub-cycles (Fig. 10). The bounding of these cycles is here based on the bandpassed MS data and on the evolution of the period of the eccentricity observed in the spectrogram. In the Agua de la Mula Member, cycle e2 may be split into two cycles. Here, the choice to maintain one cycle depends on the comparison with the evolution of the thickness on which the obliquity is recorded.

\subsection{Comparison between astrochronology and radiochronology}

The interval from the tuff POT3 to the tuff EP 1711-1712 encompasses $3.01 \pm 0.06$ myr of studied sediments (i.e. excluding the Avilé Member). The difference between the absolute ages of POT3 and EP $1711-1712$ is $3.42 \pm 0.22 \mathrm{myr}$ (quadratic uncertainty calculated from the uncertainties of the $\mathrm{U}-\mathrm{Pb}$ ages of the two tuff layers). This implies a very short duration of deposition of the Avilé Member of $0.41 \pm$ 0.23 myr. The quadratic uncertainty of the duration is comparatively high and progresses from the uncertainties of the $\mathrm{U}-\mathrm{Pb}$ ages and the astrochronology.

Two other tuff layers were dated with the CA-ID-TIMS method in the Agrio Formation at Caepe Malal and Agrio del Medio (Aguirre-Urreta et al., 2015). The record of these two tuff layers at El Portón is based on biostratigraphy with an uncertainty of $\pm 5 \mathrm{~m}$ for the record of the tuff from Agrio Medio. The tuff from Caepe Malal is located at the base of the Agua de la Mula Member, above the last sandstone layers, allowing a precise correlation of this level to El Portón. The duration between tuff EP 1711-1712 and the tuff from Agrio del Medio was used to



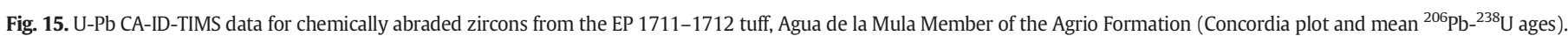


Table 1

U-Pb isotopic data of EP 1711-1712 sample from El Portón.

\begin{tabular}{|c|c|c|c|c|c|c|c|c|c|c|c|c|c|c|c|c|c|c|c|c|}
\hline \multirow[b]{2}{*}{ Grain } & \multirow[b]{2}{*}{$\frac{T h}{U}$} & \multirow[b]{2}{*}{$\begin{array}{l}{ }^{206} \mathrm{~Pb}^{*} \times \\
10^{-13} \mathrm{~mol}\end{array}$} & \multirow[b]{2}{*}{$\begin{array}{l}\mathrm{mol} \% \\
{ }^{206} \mathrm{~Pb}^{*}\end{array}$} & \multirow[b]{2}{*}{$\frac{\mathrm{Pb}^{*}}{\mathrm{Pbc}}$} & \multirow[b]{2}{*}{$\begin{array}{l}\text { Pbc } \\
(\mathrm{pg})\end{array}$} & \multirow[b]{2}{*}{$\frac{{ }^{206} \mathrm{~Pb}}{{ }^{204} \mathrm{~Pb}}$} & \multicolumn{7}{|c|}{ Radiogenic isotopic ratios } & \multirow[b]{2}{*}{$\begin{array}{l}\text { corr. } \\
\text { coef. }\end{array}$} & \multicolumn{6}{|c|}{ Radiogenic isotopic dates } \\
\hline & & & & & & & $\frac{{ }^{208} \mathrm{~Pb}}{{ }^{206} \mathrm{~Pb}}$ & $\frac{{ }^{207} \mathrm{~Pb}}{{ }^{206} \mathrm{~Pb}}$ & $\%$ err & $\frac{{ }^{207} \mathrm{~Pb}}{{ }^{235} \mathrm{U}}$ & $\%$ err & $\frac{{ }^{206} \mathrm{~Pb}}{{ }^{238} \mathrm{U}}$ & $\%$ err & & $\frac{{ }^{207} \mathrm{~Pb}}{{ }^{206} \mathrm{~Pb}}$ & \pm & $\frac{{ }^{207} \mathrm{~Pb}}{{ }^{235} \mathrm{U}}$ & \pm & $\frac{{ }^{206} \mathrm{~Pb}}{{ }^{238} \mathrm{U}}$ & \pm \\
\hline (a) & (b) & (c) & (c) & (c) & (c) & (d) & (e) & (e) & (f) & (e) & (f) & (e) & (f) & & (g) & (f) & $(\mathrm{g})$ & (f) & (g) & (f) \\
\hline \multicolumn{21}{|c|}{ EP1711-1712 } \\
\hline z6 & 0.835 & 0.4171 & $99.25 \%$ & 43.2 & 0.26 & 2402 & 0.267 & 0.048611 & 0.219 & 0.133378 & 0.263 & 0.019900 & 0.071 & 0.703 & 129.1 & 5.2 & 127.13 & 0.31 & 127.02 & 0.09 \\
\hline $\mathrm{z} 2$ & 0.951 & 0.6714 & $99.23 \%$ & 43.3 & 0.43 & 2338 & 0.304 & 0.048661 & 0.221 & 0.133487 & 0.265 & 0.019896 & 0.074 & 0.688 & 131.5 & 5.2 & 127.23 & 0.32 & 127.00 & 0.09 \\
\hline z3 & 0.728 & 0.1233 & $97.49 \%$ & 12.4 & 0.26 & 720 & 0.233 & 0.048907 & 0.700 & 0.134152 & 0.760 & 0.019894 & 0.110 & 0.599 & 143.4 & 16.4 & 127.82 & 0.91 & 126.99 & 0.14 \\
\hline $\mathrm{z} 4$ & 1.072 & 0.3291 & $99.12 \%$ & 39.1 & 0.24 & 2055 & 0.342 & 0.048562 & 0.271 & 0.133197 & 0.314 & 0.019893 & 0.075 & 0.656 & 126.7 & 6.4 & 126.97 & 0.37 & 126.98 & 0.09 \\
\hline $\mathrm{z} 5$ & 0.954 & 0.3219 & $99.04 \%$ & 34.9 & 0.26 & 1888 & 0.304 & 0.048631 & 0.256 & 0.133379 & 0.302 & 0.019892 & 0.072 & 0.713 & 130.1 & 6.0 & 127.13 & 0.36 & 126.97 & 0.09 \\
\hline $\mathrm{z} 1$ & 1.003 & 0.4305 & $99.28 \%$ & 46.7 & 0.26 & 2491 & 0.320 & 0.048479 & 0.268 & 0.132881 & 0.309 & 0.019880 & 0.071 & 0.653 & 122.7 & 6.3 & 126.68 & 0.37 & 126.90 & 0.09 \\
\hline
\end{tabular}

Notes:

(a) z1, z2, etc. are labels for single zircon grains or fragments; all fragments chemically abraded at $190{ }^{\circ} \mathrm{C}$; analyses in bold used in the weighted mean calculations.

(b) Model Th/U ratio calculated from radiogenic ${ }^{208} \mathrm{~Pb} /{ }^{206} \mathrm{~Pb}$ ratio and ${ }^{207} \mathrm{~Pb} /{ }^{235} \mathrm{U}$ date.

(c) $\mathrm{Pb}^{*}$ and $\mathrm{Pbc}$ are radiogenic and common $\mathrm{Pb}$, respectively. mol\% ${ }^{206} \mathrm{~Pb}^{*}$ is with respect to radiogenic and blank $\mathrm{Pb}$.

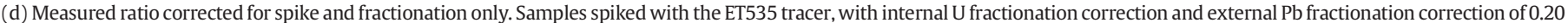
\pm 0.03 (1-sigma) \%/amu (atomic mass unit), based on analysis of NBS-981 and NBS-982.

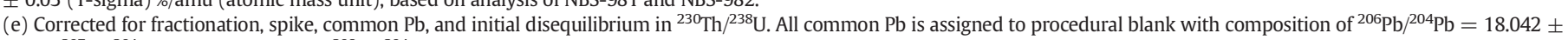
$0.61 \% ;{ }^{207} \mathrm{~Pb} /{ }^{204} \mathrm{~Pb}=15.537 \pm 0.52 \% ;{ }^{208} \mathrm{~Pb} /{ }^{204} \mathrm{~Pb}=37.686 \pm 0.63 \%$ (1-sigma).

(f) Errors are 2-sigma, propagated using algorithms of Schmitz and Schoene (2007).

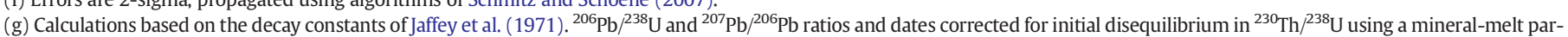
tition coefficient ratio for $\mathrm{D}_{\mathrm{Th} / \mathrm{U}}=0.2$.

attribute an orbital cycle to the 23-m cycle (Fig. 11; Section 5.1). The duration between EP 1711-1712 and the tuff from Caepe Malal is $2.12 \pm$ 0.22 myr, while astrochronology indicates a duration of $1.70 \pm$ 0.04 myr. The difference of duration of 0.42 myr is still higher than the cumulative uncertainty of $\mathrm{U}-\mathrm{Pb}$ dating and astrochronology. The shorter duration can be explained by the occurrence of a hiatus of a few hundreds of thousands of years in the Agua de la Mula Member in El Portón or by protracted crystallization of zircons, which could have lasted several hundreds of thousands of years (e.g. Simon et al., 2008). The radioastrochronological intercalibration of the Pilmatué Member implies the top of the member is $129.11 \pm 0.16$ Ma old (quadratic uncertainty), which is nearly identical to the age of the Caepe Malal tuff $(129.09 \pm$ $0.16 \mathrm{Ma}$ ). If true, it would imply that this $130-\mathrm{m}$ thick Avilé Member at El Portón would have been deposited in a few thousands of years, which seems unlikely as at least five eustatically influenced sequences have been identified in the member, implying a possible Milankovitch control on them (Rossi, 2001; Veiga et al., 2002).

Altogether, the disagreement between the age of the tuff layer at Caepe Malal and the astrochronology seems to be due to the residence time in the magmatic chamber of the zircons dated, which led to overestimate the age of this tuff layer by a few thousands of years.

\subsection{Comparisons with the chronostratigraphy of the Tethyan area}

\subsubsection{In the lower Hauterivian}

The astrochronological framework provided here gives an opportunity to independently assess the calibration of the ammonoid zones in the Neuquén Basin with the "standard" chronostratigraphy in the Tethyan area (Reboulet et al., 2014). An astrochronological framework of the Tethyan ammonoid zones was established in the La CharcePommerol section (Vocontian Basin, SE France) and the Río Argos section (Subbetic Domain, SE Spain) (Martinez et al., 2015). In Martinez et al. (2015), the calibration of the La Charce-Pommerol series was based on the 405-kyr eccentricity cycles. In the Hauterivian part of the series however, the record of the cycle was unclear, leading to an uncertainty of $\pm 405 \mathrm{kyr}$ in the duration assessment of the early Hauterivian. Recent reassessment of the mean period of the precession cycles (20.3 $\pm 0.5 \mathrm{kyr}$; Waltham, 2015) provides the opportunity to revise the time frame of the La Charce-Pommerol series (Fig. 12). The gammaray spectrometry series, detrended using three linear best-fit models (Fig. 12.A) shows a strong record of the 405-kyr eccentricity cycles from 0 to $110 \mathrm{~m}$ (with periods ranging from 28 to $11 \mathrm{~m}$ ), from the $N$. peregrinus Zone to the A. radiatus Zone (Fig. 12.C). Above the A. radiatus Zone, in the 405-kyr cycle in the record vanishes and only the precession cycle remains, with periods ranging from 0.7 to $1.0 \mathrm{~m}$ (Fig. 12.D). The revised age model of the La Charce-Pommerol series is based on the 405-kyr eccentricity cycle in the lower part, and on the precession for the upper part. The early Hauterivian notably contains 97 repetitions of the precession cycles plus $57 \%$ of the thickness of 405-kyr cycle V/H (Fig. 12). This leads to a duration of the early Hauterivian of $2.19 \pm 0.05$ myr.

Comparisons between the Andean and the Tethyan faunas in the Pilmatue Member allowed the base of the $P$. angulatiformis Zone, the base of the $H$. neuquensis Zone, the base of the $O$. (O.) laticosta Subzone, and the base of the H. giovinei Subzone to be correlated respectively to the base of the Criosarasinella furcillata Zone, the base of the A. radiatus Zone, the base of the Olcostephanus (Jeannoticeras) jeannoti Subzone and the base of the Lyticoceras nodosoplicatum Zone.

The firmest correlation of the four ammonoid levels mentioned above is the third one. The 0 . (O.) laticosta Subzone is very thin along the whole basin; in its lower part is the first occurrence of $O$. (Jeannoticeras), represented by $O$. (J.) agrioensis, which is very similar to the type species, $O$. (J.) jeannotii (Aguirre-Urreta and Rawson, 2001; Rawson, 2007). The widespread distribution of the short-lived Jeannoticeras and associated Olcostephanus species is well documented from the Boreal-Atlantic, Mediterranean-Caucasian and Indo-Pacific subrealms (Bulot, 1992; Bulot et al., 1993; Aguirre-Urreta and Rawson, 2001) and it is considered a major Hauterivian ammonite event (Lehmann et al., 2015).

Anchoring the absolute age of the lower part of the 0 . (0.) laticosta Subzone (130.22 $\pm 0.16 \mathrm{Ma}$ ) to the base of the $O$. (J.) jeannoti Subzone, the following comparisons between the two faunal provinces can be established (Fig. 16):

- The base of the C. furcillata Zone is at $131.94 \mathrm{Ma}$ as is the base of the $P$. angulatiformis Zone.

- The base of the A. radiatus Zone is at 131.29 Ma, while the base of the $H$. neuquensis Zone is at $131.16 \mathrm{Ma}$.

- The base of the L. nodosoplicatum Zone is at $129.99 \mathrm{Ma}$, while the base of the H. giovinei Subzone is at 130.08 Ma.

The maximum difference between the correlation lines is 0.13 myr. The uncertainty of the numerical ages of the Tethyan bioevents includes the measurement of the $\mathrm{U}-\mathrm{Pb}$ age $(0.16 \mathrm{Ma})$ and the correlation 




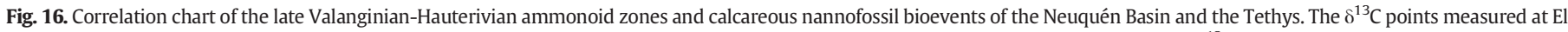

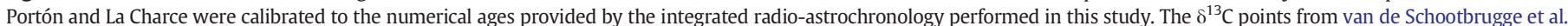

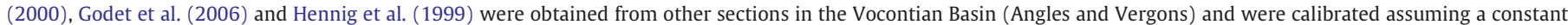
sedimentation rate within the ammonoid (sub-)zones in which the data were collected. The green area represents the 'mid'-Hauterivian minimum in $\delta^{13} \mathrm{C}$ values.

between the Neuquén Basin and the Tethyan area (0.1 Ma). The age of the Tethyan bioevents is thus given with an uncertainty of ( $\sqrt{0.16^{2}+0.12}$ ) $0.19 \mathrm{Ma}$ (Fig. 16). Accounting that the maximum age difference between these biozones is lower than the age uncertainties, these correlations can be at first order regarded as synchronous in future stratigraphic studies where astrochronology is not available.

The LO of E. windii is found 0.51 myr younger in the El Portón section than in La Charce (Fig. 16). However, as the LO of E. windii in La Charce is found just below a slump of 14 marl-limestone alternations (corresponding in time to $0.28 \mathrm{myr}$ ), at least half of the difference can be explained in the uncertainty in the position of the bioevent at La Charce. In Boreal sections, this bioevent is notably found in the equivalent of the lower part of the C. loryi Zone (Bown, 1998; Reboulet et al., 2014), which fits with the time scale proposed here (see Fig. 16).

\subsubsection{In the upper Hauterivian}

The age difference between the LO of C. cuvillieri and the LO of L. bollii is calculated at 1.54 myr at El Portón (Fig. 16), while this duration was calculated at 1.93 myr in the age model of Río Argos of Martinez et al. (2015). In addition, when applying the age model of Martinez et al. (2015) at Río Argos, the base of the S. riverorum Zone would occur around the base of the $B$. balearis Zone while in the Tethyan area, the first Sabaudiella occur at the base of the P. mortilleti subzone. Discrepancies are thus observed between the Andean and the Tethyan fauna when applying the age model of Martinez et al. (2015) for the Río Argos section.
The age model of Río Argos in Martinez et al. (2015) is a mix between the 405-kyr cycle, whose period is the most stable throughout the Mesozoic (Laskar et al., 2004), and the 100-kyr cycle, as the record of the 405-kyr cycle is absent at the base of the series. Considering the clarity of the record of the 100-kyr cycle, here the Río Argos section is calibrated on the 100-kyr cycle only and compared with the previous age model. From the base of the series to $80 \mathrm{~m}$, the bands of the $5 \mathrm{~m}$ and $1 \mathrm{~m}$ periods show the ratio of 1:5 typical for the ratio between the $100-k y r$ eccentricity and precession (Fig. 13). From $105 \mathrm{~m}$ to the top of the series, the band of $3.3 \mathrm{~m}$ and the band of $0.7 \mathrm{~m}$ show a ratio of 1:4.7 again close to the ratio of the 100-kyr eccentricity and the precession cycles. The 100-kyr cycle at Río Argos is expressed in the band of period evolving from $5.6 \mathrm{~m}$ at the base of the series to $2.9 \mathrm{~m}$ at the top of the series as already noticed in Martinez et al. $(2012,2015)$ based on the comparison of the ratios of the shortest periods (Fig. 13). The interval from 70 to $105 \mathrm{~m}$ does not show a clear record of the 100-kyr eccentricity. Spectrum whitening however shows a clear record of the precession cycles compared to the spectrogram displayed in Martinez et al. (2015); with precession periods decreasing from 1.0 and $0.8 \mathrm{~m}$. To bound the 100-kyr cycle, we applied a Taner band-pass filter using 0.0996 cycles ${ }^{*} \mathrm{~m}^{-1}$ and 0.2490 cycles* $\mathrm{m}^{-1}$ as cutoff frequencies from 0 to $100 \mathrm{~m}$ and using 0.1123 cycles $\mathrm{m}^{-1}$ and 0.3593 cycles $^{*} \mathrm{~m}^{-1}$ as cutoff frequencies from $95 \mathrm{~m}$ to the top of the series. The precession cycles were also filtered using 0.6673 cycles $^{*} \mathrm{~m}^{-1}$ and 1.1653 cycles* ${ }^{*}{ }^{-1}$ as cutoff frequencies from 0 to $100 \mathrm{~m}$ and using 0.9281 cycles* $\mathrm{m}^{-1}$ and 1.7365 cycles* $\mathrm{m}^{-1}$ as cutoff frequencies from $95 \mathrm{~m}$ to the top of the series. The interval from 66.1 to $121.1 \mathrm{~m}$ contains 60 precession cycles, 
either 12 eccentricity cycles. The filter helped in bounding the 12 cycles, and each of the cycle contains between 3.5 and 6 precession cycles, either a duration ranging from 71.4 to $120 \mathrm{kyr}$, which is also observed in the astronomical solutions (Laskar et al., 2004). In addition, two consecutive short eccentricity cycles, as bounded here, show between 8.5 and 11 precession cycles, implying a mean duration of the short eccentricity cycles ranging from 86.7 to $112.2 \mathrm{kyr}$, which is also in agreement with the astronomical solutions.

Considering an average duration of $95.6 \mathrm{kyr}$ for the short eccentricity cycle, the new time scale shortens the duration of the P. ligatus Zone from 0.92 to 0.68 myr and the duration of the B. balearis Zone from 0.72 to 0.66 myr. Importantly, the new duration of the interval from the base of the P. ligatus Zone to the base of the T. hugii Zone shortens from 2.39 myr (Martinez et al., 2015) to 2.10 myr in the revised age model here. This revised duration is in much better agreement with the duration of 2.10 to 2.26 myr calculated by cycle counting in other Tethyan sections (Bodin et al., 2006). In the revised age model, the late Hauterivian contains 32 repetitions of the short eccentricity cycle, which duration is $95.6 \pm 2 \mathrm{kyr}$. This leads to a duration of the late Hauterivian of $3.02 \pm 0.06$ myr.

Using this new age model significantly aligns the bioevents between the Andean and the Tethyan area (Fig. 16). The age difference between the Andean and the Tethyan realms of the LO of C. cuvillieri and LO of L. bollii is $139 \mathrm{kyr}$ and $266 \mathrm{kyr}$, respectively. In addition, the base of the $S$. riverorum Zone is $254 \mathrm{kyr}$ earlier than the base of the $P$. mortilleti subzone. With this time scale, the $C$. diamantensis Zone correlates with the upper part of the $S$. sayni Zone and the P. ligatus Zone, as suggested by paleontological studies in progress. The new age model of Río Argos thus provides much more consistent ages of bioevents in the late Hauterivian.

\subsection{Comparison of the trends in stable isotope data}

The $\delta^{13} \mathrm{C}$ curve can provide additional anchor points to link the Andean to the Tethyan areas (Aguirre-Urreta et al., 2008c). The main remarkable event in the trend of the $\delta^{13} \mathrm{C}$ curves in the Hauterivian is the end of the Weissert Event occurring at the early/late Hauterivian transition (Fig. 16; see also van de Schootbrugge et al., 2000). In the El Portón section, the $\delta^{13} \mathrm{C}$ values sharply decrease in the mid-Hauterivian, marking this event. According to the time scales produced in the Andean and Tethyan realms, this event appears synchronous, making a trustable correlation line to anchor the Andean to the Tethyan realm.

Overall, the $\delta^{13} \mathrm{C}$ values of the El Portón section, ranging from -3.52 to $+1.40 \%$ 。 $\mathrm{V}$-PDB show higher variability than the $\delta^{13} \mathrm{C}$ values of the Vocontian Basin, ranging from 0.51 to $1.78 \%$ V-PDB (Fig. 16). Despite this difference of variability, the $\delta^{13} \mathrm{C}$ values decrease throughout the early Hauterivian in both the Neuquén and the Vocontian basins. In the El Portón section, the mean $\delta^{13} \mathrm{C}$ values progressively decrease throughout the early Hauterivian, from $0.87 \%$ at 131.3 Ma to $0.45 \%$ o at $129.3 \mathrm{Ma}$, while in the Vocontian Basin, the mean $\delta^{13} \mathrm{C}$ values decrease from $1.5 \%$ at $131.3 \mathrm{Ma}$ to $1.03 \%$ at $129.3 \mathrm{Ma}$. Within the early Hauterivian, both basins show local maxima in $\delta^{13} \mathrm{C}$ values at 131.3 , 130.4 and $129.3 \mathrm{Ma}$ (Fig. 16). Only the local maximum at $129.8 \mathrm{Ma}$ is not observed in the Vocontian Basin due to a lack of samples.

In the late Hauterivian, the $\delta^{13} \mathrm{C}$ curve gently increases in the Vocontian Basin from $0.81 \%$ at $128.4 \mathrm{Ma}$ to $1.19 \%$ at $127.3 \mathrm{Ma}$. Instead, the $\delta^{13} \mathrm{C}$ curve of the El Portón section rapidly increases from $0.16 \%$ at $128.4 \mathrm{Ma}$ to $1.01 \%$ at $128.1 \mathrm{Ma}$ and then stabilizes around this mean value to $127.2 \mathrm{Ma}$. The $\delta^{13} \mathrm{C}$ values then rapidly decrease to $-0.3 \%$ at 127.1 Ma in El Portón, while in the Vocontian Basin the $\delta^{13} \mathrm{C}$ values transiently stabilize around $1.20 \%$ from 127.4 to $127.1 \mathrm{Ma}$. Unlikely to the early Hauterivian, the $\delta^{13} \mathrm{C}$ curves do not show the same trends from the $P$. ligatus to the $B$. balearis Tethyan zones (i.e. from the upper half of the $C$. diamantensis to the S. riverorum Andean zones). It is noteworthy that the increase in $\delta^{13} \mathrm{C}$ stops in the El Porton section while the MS values suddenly increase (Fig. 11). This lack of correlation in the trends is not surprising, as the $\delta^{13} \mathrm{C}$ signal includes a local response to the carbon cycle, such as the change in the type of carbonate producer or the detrital flux from the continent (Föllmi et al., 2006; Godet et al., 2006). In the Umbria-Marche Basin, the Fiume-Bosso section records in the late Hauterivian a rapid increase in the $\delta^{13} \mathrm{C}$ values after the minimum in the "mid"-Hauterivian, then a stabilization of the values around $2 \%$ and a rapid decrease to $1.7 \%$, likely in the $B$. balearis Zone (Sprovieri et al., 2006). The $\delta^{13} \mathrm{C}$ values then only increase around the Faraoni interval. This trend in the $\delta^{13} \mathrm{C}$ appears closer to trend observed at El Portón than in the Vocontian Basin. In summary, all sections having provided bulk $\delta{ }^{13} \mathrm{C}$ data show a minimum in the $\delta{ }^{13} \mathrm{C}$ values in the "mid"-Hauterivian and a long-term decrease throughout the early Hauterivian. Trends may differ from a basin to another in the latest Valanginian and in the upper part of the late Hauterivian depending on local response to the carbon cycle.

\subsection{Implications for the next Geological Time Scale in the Early Cretaceous}

The revised astrochronology of the La Charce-Pommerol section leads to a duration of the early Hauterivian of $2.19 \pm 0.05$ myr (Figs. 12, 16). This duration falls within the previous astrochronological assessment at $2.51 \pm 0.41 \mathrm{Ma}$ (Martinez et al., 2015), and contrasts with the estimate of 1.36 myr in the last Geological Time Scale 2016 (Ogg et al., 2016). The early Hauterivian in the El Portón section corresponds to the interval from the base of the $H$. neuquensis Zone to the base of the Avile Member. The duration of this interval in the El Portón section is calculated at $2.15 \mathrm{myr}$, in good agreement with the Tethyan area (Figs. 10-12). The difference of 0.04 myr between the two areas may be due to the uncertainties of the correlations between the Andean and the Tethyan areas, and to the fact that the early-late Hauterivian boundary may be located within the nonmarine Avilé Member. Considering these sources of uncertainty, the durations of the early Hauterivian is reproducible from the Tethyan and the Andean areas.

The astrochronology of the Agua de la Mula Member at El Portón shows that the duration of the late Hauterivian was overestimated by 0.4 myr in Martinez et al. (2015). The revised time scale of the Río Argos section shows more consistent ages of the bioevents between the Andean and the Tethyan realms. Even though the duration of the late Hauterivian decreases from 3.43 myr to $3.02 \pm 0.06$ myr, the length of the whole Hauterivian increases from 3.9 myr (Ogg et al., 2016) to $5.21 \pm 0.08$ myr (quadratic uncertainty from the duration uncertainties of the early and late Hauterivian). In this study, it is suggested that the Hauterivian started at $131.29 \pm 0.19 \mathrm{Ma}$ and ended at $126.08 \pm$ $0.19 \mathrm{Ma}$. These ages differ from the GTS 2016, which suggests the Hauterivian started at $134.69 \mathrm{Ma}$ and ended at $130.77 \mathrm{Ma}$. The GTS 2016 compilation bases the duration of the Hauterivian Stage on the work of Sprovieri et al. (2006) in the Umbria-Marche Basin (Central Italy) whose recognition of the $405-\mathrm{kyr}$ is only based on the $\delta^{13} \mathrm{C}$ and with no record of higher-frequency cycles. The recognition of the 405kyr cycle in the $\delta^{13} \mathrm{C}$ may suffer from the residence time of carbon in the oceans (Laurin et al., 2017) and from the change in the source of carbonate, which change the phasing of carbonate $\delta^{13} \mathrm{C}$ relative to the insolation (Martinez, 2018). Thus, the reliable identification of the 405-kyr cycle in the Umbria-Marche Basin requires the use of additional proxies sampled at higher resolution.

\section{Conclusions}

An integrated radio-astrochronological framework of the Agrio Formation in the El Portón section is shown here to provide new constraint on the age and duration of late Valanginian-Hauterivian times. Biostratigraphic data anchor this time scale to the Tethyan area and provide detailed interhemispheric correlations for the Early Cretaceous, which are quite uncommon for Mesozoic times. The new time scale revises the astrochronology of the Tethyan area, and notably the La CharcePommerol composite section, for which new ammonoid data are 
given here, and the Río Argos section. With this revised time scale, the maximum difference in the age of biostratigraphic events is $0.13 \mathrm{myr}$ in the early Hauterivian and $0.27 \mathrm{myr}$ in the late Hauterivian, which represents a significant progress in the construction of an accurate time scale for the Early Cretaceous. Correlations based on $\delta^{13} \mathrm{C}$ commonly show a minimum in the $\delta^{13} \mathrm{C}$ values around the early-late Hauterivian transition and a long-term decrease in the $\delta^{13} \mathrm{C}$ values in the early Hauterivian. Trends in the ${ }^{13} \mathrm{C}$ values differ from a basin to another in the upper part of the late Hauterivian, likely depending on the local response on the carbon cycle. According to our calibration, the minimum in the $\delta^{13} \mathrm{C}$ values in the "mid"-Hauterivian appears to be synchronous and, thus, an important stratigraphic marker for global correlation. The new duration of the Hauterivian is calculated at $5.21 \pm 0.08 \mathrm{myr}$, with the Hauterivian Stage starting $131.29 \pm 0.19$ Ma and ending $126.08 \pm 0.19 \mathrm{Ma}$.

Supplementary data to this article can be found online at https://doi. org/10.1016/j.gr.2019.01.006.

\section{Acknowledgements}

The authors acknowledge with special thanks the valuable revision of Miguel Company and the editorial work of R. Damian Nance. Two anonymous reviewers are also acknowledged. BAU, ML, AC and VAR acknowledge the grants from CONICET, UBA and ANPCyT. MM, HP and A-L $\mathrm{N}$ are supported by ERC Consolidator grant Earthsequencing. HK was partially funded through DFG EXC 309/FZT 15. This is contribution R277 of the Instituto de Estudios Andinos “Don Pablo Groeber".

\section{References}

Aguado, R., Company, M., O'Dogherty, L., Sandoval, J., Tavera, J.M., 2014. Late Hauterivianearly Barremian calcareous nannofossil biostratigraphy, palaeoceanography, and stable isotope record in the Subbetic domain (southern Spain). Cretaceous Research 49, 105-124.

Aguirre-Urreta, M.B., Rawson, P.F., 1997. The ammonite sequence in the Agrio Formation (Lower Cretaceous), Neuquén basin, Argentina. Geological Magazine 134, 449-458.

Aguirre-Urreta, M.B., Rawson, P.F., 2001. Lower Cretaceous ammonites from the Neuquén Basin, Argentina: the Hauterivian Olcostephanus fauna. Cretaceous Research 22, 763-778.

Aguirre-Urreta, M.B., Rawson, P.F., 2012. Lower Cretaceous ammonites from the Neuquén Basin, Argentina: a new heteromorph fauna from the uppermost Agrio Formation. Cretaceous Research 35, 208-216.

Aguirre-Urreta, M.B., Rawson, P.F., Concheyro, G.A., Bown, P.R., Ottone, E.G., 2005. Lower Cretaceous (Berriasian-Aptian) biostratigraphy of the Neuquén Basin. In: Veiga, G., Spalletti, L., Howell, J.A., Schwarz, E. (Eds.), The Neuquén Basin: A Case Study in Sequence Stratigraphy and Basin Dynamics. Geological Society of London, Special Publication vol. 252, pp. 57-81.

Aguirre-Urreta, M.B., Mourgues, A.F., Rawson, P.F., Bulot, L.G., Jaillard, E., 2007. The Lower Cretaceous Chañarcillo and Neuquén Andean basins: ammonoid biostratigraphy and correlations. Geological Journal 42, 143-173.

Aguirre-Urreta, M.B., Pazos, P.J., Lazo, D.G., Fanning, C.M., Litvak, V.D., 2008a. First U-Pb SHRIMP age of the Hauterivian stage, Neuquén Basin, Argentina. Journal of South American Earth Sciences 26, 91-99.

Aguirre-Urreta, M.B., Casadío, S., Cichowolski, M., Lazo, D.G., Rodríguez, D., 2008b. Afinidades paleobiogeográficas de los invertebrados cretácicos de la cuenca Neuquina. Ameghiniana 45, 593-613.

Aguirre-Urreta, M.B., Price, G.D., Ruffell, A.H., Lazo, D.G., Kalin, R.M., Ogle, N., Rawson, P.F., 2008c. Southern Hemisphere Early Cretaceous (Valanginian-Early Barremian) carbon and oxygen isotope curves from the Neuquén Basin, Argentina. Cretaceous Research 29, 87-99.

Aguirre-Urreta, B., Lescano, M., Schmitz, M.D., Tunik, M., Concheyro, A., Rawson, P.F., Ramos, V.A., 2015. Filling the gap: new precise Early Cretaceous radioisotopic ages from the Andes. Geological Magazine 152, 557-564.

Aguirre-Urreta, B., Schmitz, M., Lescano, M., Tunik, M., Rawson, P.F., Concheyro, A., Buhler, M., Ramos, V.A., 2017. A high precision U-Pb radioisotopic age for the Agrio Formation, Neuquén Basin, Argentina: implications for the chronology of the Hauterivian Stage. Cretaceous Research 75, 193-204.

Allen, C.M., Campbell, I.H., 2012. Identification and elimination of a matrix-induced systematic error in LA-ICP-MS ${ }^{206} \mathrm{~Pb} /{ }^{238} \mathrm{U}$ dating of zircon. Chemical Geology 332-333, 157-165. https://doi.org/10.1016/j.chemgeo.2012.09.038.

Applegate, J., Bergen, J., 1988. Cretaceous calcareous nannofossil biostratigraphy of sediments recovered from the Galicia Margin, ODP Leg 103. In: Boillot, G., Winterer, E.L., Meyer, A.W., et al. (Eds.), Proceedings of the Ocean Drilling Project, Scientific Results 103, pp. 293-348 (College Station, Texas).

Ballent, S., Concheyro, A., Náñez, C., Pujana, I., Lescano, M., Carignano, A.P., Caramés, A., Angellozzi, G., Ronchi, D., 2011. Microfósiles mesozoicos y cenozoicos. In: Leanza, H.A.,
Arregui, C., Carbone, O., Danieli, J.C., Vallés, J.M. (Eds.), Geología y recursos naturales de la provincia del Neuquén. Asociación Geológica Argentina, Buenos Aires, pp. 489-528.

Barbarin, N., Bonin, A., Mattioli, E., Pucéat, E., Cappetta, H., Gréselle, B., Pittet, B., Vennin, E. Joachimski, M., 2012. Evidence for a complex Valanginian nannoconid decline in the Vocontian basin (South East France). Marine Micropaleontology 84-85, 37-53.

Baudin, F., Busnardo, R., Beltran, C., de Rafélis, M., Renard, M., Charollais, J., Clavel, B., 2006. Enregistrement de l'événement anoxique Faraoni (Hauterivien supérieur) dans le domaine ultrahelvétique. Revue de Paléobiologie 25, 525-535.

Bergen, J., 1994. Berriasian to Early Aptian calcareous nannofossils from the Vocontian Trough (SE France) and Deep Sea Drilling Site 534: new nannofossil taxa and a summary of low-latitude biostratigraphic events. Journal of Nannoplankton Research 16, 59-69.

Black, M., 1971. Coccoliths of the Speeton Clay and Sutterby Marl. Proceedings of the Yorkshire Geological Society 38, 381-424.

Bodin, S., Godet, A., Föllmi, K.B., Vermeulen, J., Arnaud, H., Strasser, A., Fiet, N., Adatte, T 2006. The late Hauterivian Faraoni oceanic anoxic event in the western Tethys: evidence from phosphorus burial rates. Palaeogeography, Palaeoclimatology, Palaeoecology 235, 245-264.

Bown, P.R., 1998. Calcareous Nannofossil Biostratigraphy. British Micropaleontological Society Publication Series. Chapman and Hall, Kluwer Academic Publishers, London (314 pp.).

Bown, P.R., Concheyro, A., 2004. Lower Cretaceous calcareous nannoplankton from the Neuquén Basin, Argentina. Marine Micropaleontology 52, 51-84.

Bown, P.R., Young, J.R., 1997. Mesozoic calcareous nannoplankton classification. Journal of Nannoplankton Research 19, 21-36.

Bralower, T., 1987. Valanginian to Aptian calcareous nannofossil stratigraphy and correlation with the upper M-sequence magnetic anomalies. Marine Micropaleontology 11, 293-310.

Bralower, T.J. Leckie, R.M., Sliter, W.V., Thierstein, H.R. 1995. An integrated Cretaceous microfossil biostratigraphy. In: Berggren, W.A., Kent, D.V., Aubry, M.-P., Hardenbol, J. (Eds.), Geochronology, Time Scales and Global Stratigraphic Correlation. Society of Economic Paleontologists and Mineralogists, Special Publication vol. 54, pp. 65-79.

Bulot, L.G., 1992. Les Olcostephaninae valanginiens et hauteriviens (Ammonitina, Cephalopoda) du Jura Franco-Suisse: systématique et intérêt biostratigraphique. Revue de Paléobiologie 11, 149-166.

Bulot, L., 1995. Les formations à ammonites du Crétacé inférieur dans le Sud-Est de la France (Berriasien à Hauterivien) : biostratigraphie, paléontologie et cycles sédimentaires. Unpublished PhD thesis. Muséum National d'Histoire Naturelle, Paris (398pp.).

Bulot, L.G., Thieuloy, J.-P., Blanc, E., Klein, J., 1993. Le cadre stratigraphique du Valanginien supérieur et de l'Hauterivien du Sud-Est de la France: définition des biochronozones et caractérisation de nouveaux biohorizons. Géologie Alpine 68, 13-56.

Busnardo, R., Charollais, J., Weidmann, M., Clavel, B., 2003. Le Crétacé inférieur de la Veveyse de Châtel (Ultrahelvétique des Préalpes externes; canton de Fribourg, Suisse). Revue de Paléobiologie 22, 1-174.

Cecca, F., Pallini, G., Erba, E., Premoli-Silva, I., Coccioni, R., 1994. Hauterivian-Barremian chronostratigraphy based on ammonites, nannofossils, planktonic foraminifera and magnetic chrons from the Mediterranean domain. Cretaceous Research 15, 457-467.

Cecca, F., Faragni, P., Marini, A., 1998. Latest Hauterivian (Early Cretaceous) ammonites from Umbria-Marche Apennines (central Italy). Palaeontographia Italica 85, 61-110.

Channell, J.E.T., Erba, E., 1992. Early Cretaceous polarity chrons CM0 to CM11 recorded in northern Italian sections near Brescia. Earth and Planetary Science Letters 108, 161-179.

Channell, J.E.T., Bralower, T.J., Grandesso, P., 1987. Biostratigraphic correlation of M sequence chrons CM1 to CM23 at Capriolo and Xausa (S. Alps, Italy). Earth and Planetary Science Letters 85, 203-221.

Channell, J.E.T., Erba, E., Nakanishi, M., Tamaki, K., 1995. Late Jurassic-Early Cretaceous time scales and oceanic magnetic anomaly block models. In: Berggren, W.A., Kent, D.V., Aubry, M., Hardenbol, J. (Eds.), Geochronology, Time Scales and Stratigraphic Correlation. Society of Economic Paleontologists and Mineralogists, Special Publication vol. 54, pp. 51-63.

Charbonnier, G., Boulila, S., Gardin, S., Duchamp-Alphonse, S., Adatte, T., Spangenberg, J.E. Föllmi, K.B., Colin, Ch., Galbrun, B., 2013. Astronomical calibration of the Valanginian "Weissert" episode: the Orpierre marl-limestone succession (Vocontian Basin, southeastern France). Cretaceous Research 45, 25-42.

Cleveland, W.S., 1979. Robust locally weighted regression and smoothing scatterplots. Journal of the American Statistical Association 74, 829-836.

Comerio, M., Fernández, D.E., Pazos, P.J., 2018. Sedimentological and ichnological characterization of muddy storm related deposits: the upper Hauterivian ramp of the Agrio Formation in the Neuquén Basin, Argentina. Cretaceous Research 85, 78-94.

Company, M., Sandoval, J., Tavera, J.M., 2003. Ammonite biostratigraphy of the uppermost Hauterivian in the Betic Cordillera (SE Spain). Geobios 36, 685-694.

Company, M., Aguado, R., Sandoval, J., Tavera, J.M., Jiménez de Cisneros, C., Vera, J.A., 2005 Biotic changes linked to a minoranoxic event (Faraoni level, latest Hauterivian, Early Cretaceous). Palaeogeography, Palaeoclimatology, Palaeoecology 224, 186-199.

Company, M., Sandoval, J., Tavera, J.M., Aoutem, M., Ettachfini, M., 2008. Barremian ammonite faunas from the western High Atlas, Morocco - biostratigraphy and palaoebiogeography. Cretaceous Research 29, 9-26.

Concheyro, A., Lescano, M., Caramés, A., Ballent, S., 2009. Micropaleontología de la Formación Agrio (Cretácico inferior) en distintos sectores de la cuenca Neuquina. Revista de la Asociación Geológica Argentina 65, 342-361.

Condon, D.J., Schoene, B., McLean, N.M., Bowring, S.A., Parrish, R.R., 2015. Metrology and traceability of U-Pb isotope dilution geochronology (EARTHTIME Tracer Calibration Part I). Geochimica et Cosmochimica Acta 164, 464-480. https://doi.org/10.1016/j. gca.2015.05.026.

Covington, J., Wise, S., 1987. Calcareous nannofossil biostratigraphy of a Lower Cretaceous deep-sea fan complex. Deep Sea Drilling Project Leg 93 Site 603, lower 
continental rise off Cape Hatteras. Initial Reports of the Deep Sea Drilling Project 93, 617-660.

Davydov, V.I., Crowley, J.L., Schmitz, M.D., Poletaev, V.I., 2010. High-precision U-Pb zircon age calibration of the global Carboniferous time scale and Milankovitch-band cyclicity in the Donets Basin, eastern Ukraine. Geochemistry, Geophysics, Geosystems 11, Q0AA04. https://doi.org/10.1029/2009GC002736.

Duchamp-Alphonse, S., Fiet, N., Adatte, T., Pagel, M., 2007. Climate and sea-level variations along the northwestern Tethyan margin during the Valanginian C-isotope excursion: Mineralogical evidence from the Vocontian Basin (SE France). Palaeogeography, Palaeoclimatology, Palaeoecology 302, 243-254.

Edwards, A., 1963. A preparation technique for calcareous nannoplankton. Micropaleontology 9, 103-104.

Embry, A., Klovan, J.E., 1971. A late Devonian reef tract on northeastern Banks Island Northwest Territories. Bulletin of Canadian Petroleum Geology 19, 730-781.

Esmeray-Senlet, S., Minguez, D., Gradstein, F., 2018. The Barremian-aptian Boundary Controversy: Evaluation of the Numerical Age. GSA Annual Meeting, Indianapolis, Paper No. 241-9.

Föllmi, K.B., Godet, A., Bodin, S., Linder, P., 2006. Interactions between environmental change and shallow water carbonate buildup along the northern Tethyan margin and their impact on the Early Cretaceous carbon isotope record. Paleoceanography 21, PA4211. https://doi.org/10.1029/2006PA001313.

Gardin, S., 2008. Chapter 3. The nannofossil succession of La Charce across theValanginian-Hauterivian boundary. In: Mattioli, E. (Ed.), 12th Meeting of the International Nannoplankton Association (Lyon, September 7-10, 2008): Guidebook for the Post-Congress Fieldtrip in the Vocontian Basin, SE France (September 11-13, 2008). Notebooks on Geology. International Nannoplankton Association, Brest, France, pp. 11-13.

Gardin, S., Bulot, L.G., Coccioni, R., De Wever, P., Hishida, K., Lambert, E., 2000. The Valanginian to Hauterivian Hemipelagic Successions of the Vocontian Basin (SE France): New High Resolution Integrated Biostratigraphical Data. 6th International Cretaceous Symposium (Vienna), Abstracts. p. 34.

Godet, A., Bodin, S., Föllmi, K.B., Vermeulen, J., Gardin, S., Fiet, N., Adatte, T., Berner, Z. Stüben, D., van de Schootbrugge, B., 2006. Evolution of the marine stable carbonisotope record during the early Cretaceous: a focus on the late Hauterivian and Barremian in the Tethyan realm. Earth and Planetary Science Letters 242, 254-271.

Gradstein, F.M., Ogg, J.G., Schmitz, M.D., Ogg, G.M., 2012. The Geologic Time Scale 2012 Elsevier (1144 pp.)

Gréselle, B., Pittet, B., Mattioli, E., Joachimski, J., Barbarin, N., Riquier, L., Reboulet, S. Pucéat, E., 2011. The Valanginian isotope event: a complex suite of palaeoenvironmental perturbations. Palaeogeography, Palaeoclimatology, Palaeoecology 306, 41-57.

Groeber, P., 1946. Observaciones geológicas a lo largo del meridiano 70. I. Hoja Chos Malal. Revista de la Sociedad Geológica Argentina 1,177-208.

Gulisano, C.A., Gutiérrez Pleimling, A., 1988. Depósitos eólicos del Miembro Avilé (Formación Agrio, Cretácico inferior) en el norte del Neuquén, Argentina. Segunda Reunión Argentina de Sedimentología, Actas, pp. 120-124.

He, H.Y., Pan, Y.X., Tauxe, L., Qin, H.F., Zhu, R.X., 2008. Toward age determination of the MOr (Barremian-Aptian boundary) of the Early Cretaceous. Physics of the Earth and Planetary Interiors 169, 41-48.

Hennig, S., Weissert, H., Bulot, L., 1999. C-isotope stratigraphy, a calibration tool between ammonite- and magnetostratigraphy: the Valanginian-Hauterivian transition. Geologica Carpathica 50, 91-96.

Hoedemaeker, P.J., Leereveld, H., 1995. Biostratigraphy and sequence stratigraphy of the Berriasian-lowest Aptian (Lower Cretaceous) of the Río Argos succession, Caravaca, SE Spain. Cretaceous Research 16, 195-230.

Hoedemaeker, P.J., Bulot, L., Avram, E., Busnardo, R., Company, M., Delanoy, G., Kakabadze M., Kotetishvilli, E., Krishna, J., Kvantaliani, I., Latil, J.-L., Memmi, L., Rawson, P.F. Sandoval, J., Tavera, J.M., Thieuloy, J.-P., Thomel, G., Vašǐček, Z., Vermeulen, J., 1990. Preliminary ammonite zonation for the Lower Cretaceous of the Mediterranean region. Géologie Alpine 66, 123-127.

Hoedemaeker, P.J., Reboulet, S., Aguirre-Urreta, M.B., Alsen, P., Aoutem, M., Atrops, F., Barragan, R., Company, M., González Arreola, C., Klein, J., Lukeneder, A., Ploch, I. Raisossadat, N., Rawson, P.F., Ropolo, P., Vašiček, Z., Vermeulen, J., Wippich, M.G.E. 2003. Report on the $1^{\text {st }}$ International Workshop of the IUGS Lower Cretaceous Ammonite Working Group, the "Kilian Group” (Lyon, 11 July 2002). Cretaceous Research 24, 805 89-94, and erratum.

Jaffey, A.H., Flynn, K.F., Glendenin, L.E., Bentley, W.C., Essling, A.M., 1971. Precision measurements of half-lives and specific activities of ${ }^{235} \mathrm{U}$ and ${ }^{238} \mathrm{U}$. Physical Review $\mathrm{C} 4$ 1889-1906.

Jakubowski, M., 1987. A proposed Lower Cretaceous calcareous nannofossil zonation scheme for the Moray Firth area of the North Sea. Abhandlungen der Geologischen Bundesanstalt (Wien) 39, 99-119.

Jeremiah, J., 2001. A Lower Cretaceous nannofossil zonation for the North Sea Basin. Journal of Micropalaeontology 20, 45-80.

Kessels, K., Mutterlose, J., Michalzik, D., 2006. Early Cretaceous (Valanginian-Hauterivian) calcareous nannofossils and isotopes of the northern hemisphere: proxies for the understanding of Cretaceous climate. Lethaia 39, 157-172.

Klein, J., 2005. Lower Cretaceous Ammonites I, Perisphinctaceae 1: Himalayitidae, Olcostephanidae, Holcodiscidae, Neocomitidae, Oosterellidae. In: Riegraf, W. (Ed.) Fossilium Catalogus I: Animalia. Backhuys Publishers, Leiden, Netherlands (pars 139, 484 pp.).

Klein, J., Vašǐček, Z., 2011. Lower Cretaceous Ammonites V, Desmoceratoidea. In: Riegraf, W. (Ed.), Fossilium Catalogus I: Animalia. Backhuys-Margraf Publishers, Weikersheim, Germany (pars 148, 311 pp.)

Klein, J., Busnardo, R., Company, M., Delanoy, G., Kakabadze, M., Reboulet, S., Ropolo, P. Vašíček, Z., Vermeulen, J., 2007. Lower Cretaceous Ammonites III. Bochianitoidea,
Protancyloceratoidea, Ancyloceratoidea, Ptychoceratoidea. In: Riegraf, W. (Ed.), Fossilium Catalogus I: Animalia. Backhuys Publishers, Leiden, Netherlands (pars 144,381 pp.)

Klein, J., Hoffmann, R., Joly, B., Shigeta, Y., Vašǐček, Z., 2009. Lower Cretaceous Ammonites IV. Boreophylloceratoidea, Phylloceratoidea, Lytoceratoidea, Tetragonitoidea, Haploceratoidea including the Upper Cretaceous representatives. In: Riegraf, W. (Ed.), Fossilium Catalogus I: Animalia. Backhuys Publishers, Leiden, Netherlands (pars 146, $416 \mathrm{pp}$.).

Laskar, J., Robutel, P., Joutel, F., Gastineau, M., Correia, A.C.M., Levrard, B., 2004. A longterm numerical solution for the insolation quantities of the Earth. Astronomy and Astrophysics 428, 261-285.

Laurin, J., Růžek, B., Giorgioni, M., 2017. Orbital signals in carbon isotopes: phase distortion as a signature of the carbon cycle. Paleoceanography 32, 1236-1255.

Lazo, D., Cichowolski, M., Rodriguez, D., Aguirre-Urreta, M.B., 2005. Lithofacies, palaeoecology and palaeoenvironments of the Agrio Formation, Lower Cretaceous of the Neuquén basin, Argentina. In: Veiga, G.D., Spalletti, L.A., Howell, J.A., Schwarz, E. (Eds.), The Neuquén Basin: A Case Study in Sequence Stratigraphy and Basin Dynamics. The Geological Society, Special Publication vol. 252, pp. 295-315.

Lazo, D.G., Cataldo, C.S., Luci, L., Aguirre-Urreta, B., 2017. Groeber y los invertebrados fósiles del Miembro La Tosca, Cretácico Inferior de la Cuenca Neuquina: una historia de controversias paleontológicas. Revista de la Asociación Geológica Argentina 74, $19-39$.

Leanza, H.A., Hugo, C., 2001. Hoja Geológica Zapala, Hoja 3969-I, 1:250.000. Instituto de Geología y Recursos Minerales, Boletín 275, 1-128.

Legarreta, L., Gulisano, C., 1989. Análisis estratigráfico secuencial de la Cuenca Neuquina (Triásico superior-Terciario inferior). In: Chebli, G., Spalletti, L. (Eds.), Cuencas Sedimentarias Argentinas. Facultad de Ciencias Naturales, Universidad Nacional de Tucumán, Correlación Geológica Serie vol. 6, pp. 221-243.

Legarreta, L., Uliana, M.A., 1991. Jurassic-Cretaceous marine oscillations and geometry of a back-arc basin fill, central Argentine Andes. In: MacDonald, D.I.M. (Ed.), Sedimentation, Tectonics and Eustasy. Sea Level Changes at Active Margins. International Association of Sedimentologists. Special Publication vol. 12, pp. 429-450.

Lehmann, J., Ifrim, C., Bulot, L., Frau, C., 2015. Paleobiogeography of Early Cretaceous ammonoids. In: Klug, C., et al. (Eds.), Ammonoid Paleobiology: From Macroevolution to Paleogeography. Topics in Geobiology vol. 44, pp. 229-258.

Lena, L., López-Martínez, R., Lescano, M., Aguirre-Urreta, B., Concheyro, A., Vennari, V., Naipauer, M., Samankassou, E., Pimentel, M., Ramos, V., Schaltegger, U., 2019. High-precision U-Pb ages in the Early Tithonian to Early Berriasian and implications for the numerical age of the Jurassic/Cretaceous boundary. Solid Earth 10, $1-14$.

Lescano, M., Concheyro, A., 2009. Nanofósiles calcáreos de la Formación Agrio (Cretácico inferior) en el sector sudoccidental de la Cuenca Neuquina, Argentina. Ameghiniana 46, 73-94

Lescano, M., Concheyro, A., 2014. Nanocónidos del Grupo Mendoza (Cretácico Inferior) en la Provincia del Neuquén, República Argentina: Taxonomía, cronoestratigrafía e implicancias paleogeográficas. Ameghiniana 51, 466-499.

Lescano, M.A., Lazo, D.G., Cataldo, C.S., Aguirre-Urreta, M.B., Concheyro, A., 2015. Primer hallazgo de nanofósiles calcáreos en el Miembro La Tosca, Formación Huitrín, sierra de Cara Cura, Mendoza. Reunión de Comunicaciones Asociación Paleontológica Argentina 2015, Resúmenes. pp. 71-72.

Martín, J.M., Braga, J.C., Aguirre, J., Puga-Barnabéu, A., 2009. History and evolution of the North-Betic Strait (Prebetic Zone, Betic Cordillera): a narrow, early Tortonian, tidaldominated, Atlantic-Mediterranean marine passage. Sedimentary Geology 216, 80-90.

Martinez, M., 2018. Mechanisms of preservation of the long Milankovitch cycles in detrital supply and carbonate production in hemipelagic marl-limestone alternations. In: Montenari, M. (Ed.), Stratigraphy \& Timescales. vol. 3, pp. 189-218.

Martinez, M., Pellenard, P., Deconinck, J.-F., Monna, F., Riquier, L., Boulila, S., Moiroud, M., Company, M., 2012. An orbital floating time scale of the Hauterivian/Barremian GSSP from a magnetic susceptibility signal (Río Argos, Spain). Cretaceous Research 36, $106-115$

Martinez, M., Deconinck, J.-F., Pellenard, P., Reboulet, S., Riquier, L., 2013. Astrochronology of the Valanginian Stage from reference sections (Vocontian Basin, France) and palaeoenvironmental implications for the Weissert Event. Palaeogeography, Palaeoclimatology, Palaeoecology 376, 91-102.

Martinez, M., Deconinck, J.-F., Pellenard, P., Riquier, L., Company, M., Reboulet, S., Moiroud, M., 2015. Astrochronology of the Valanginian - Hauterivian stages (Early Cretaceous): chronological relationships between the Parana-Etendeka large igneous province and the Weissert and the Faraoni events. Global and Planetary Change 131, $158-173$

Mattinson, J.M., 2005. Zircon U-Pb chemical abrasion ("CA-TIMS") method: combined annealing and multi-step partial dissolution analysis for improved precision and accuracy of zircon ages. Chemical Geology 220, 47-66.

McLean, N.M., Condon, D.J., Schoene, B., Bowring, S.A., 2015. Evaluating uncertainties in the calibration of isotopic reference materials and multi-element isotopic tracers (EARTHTIME Tracer Calibration Part II). Geochimica et Cosmochimica Acta 164, 481-501. https://doi.org/10.1016/j.gca.2015.02.040.

Méndez, V., Zanettini, J.C.M., Zappettini, E.O., 1995. Geología y metalogénesis del Orógeno Andino Central, República Argentina. Anales de la Secretaría de Minería 23, 1-190.

Moiroud, M., Martinez, M., Deconinck, J.-F., Monna, F., Pellenard, P., Riquier, L., Company, M. 2012. High-resolution clay mineralogy as a proxy for orbital tuning: example of the Hauterivian-Barremian transition in the Betic Cordillera (SE Spain). Sedimentary Geology 282, 336-346.

Morales, C., Kujau, A., Heimhofer, U., Mutterlose, J., Spangenberg, J.E., Adatte, T., Ploch, I., Follmi, K.B., 2015. Palaeoclimate and palaeoenvironmental changes through the 
onset of the Valanginian carbon-isotope excursion: evidence from the Polish Basin. Palaeogeography, Palaeoclimatology, Palaeoecology 426, 183-198.

Mutterlose, J.C., Autran, G., Baraboschkin, E.J., Cecca, F., Erba, E., Gardin, S., Herngren, H., Hoedemaker, P., Kakabadze, M., Klein, J., Leereveld, H., Rawson, P.F., Ropolo, P., Vasicek, Z., Von Salis, K., 1996. The Hauterivian Stage. Bulletin de L'Institut Royal des Sciences Naturelles de Belgique 66, 19-24 (Supplement).

Nasdala, L., Lengauer, C.L., Hanchar, J.M., Kronz, A., Wirth, R., Blanc, P., Kennedy, A.K., Seydoux-Guillaume, A.M., 2002. Annealing radiation damage and the recovery of cathodoluminescence. Chemical Geology 191, 121-140.

Noclin, N., 2017. La coupe de Pommerol (Drôme, France; Bassin Vocontien, Hauterivien inférieur): étude biostratigraphique et corrélation avec la coupe de La Charce (Drôme, candidate GSSP Hauterivien). Report of Licence. vol. 3. University of Lyon (unpublished, 4 p.).

Ogg, J.G., Hinnov, L.A., 2012. Cretaceous. In: Gradstein, F., Ogg, J.G., Schmitz, M.D., Ogg, G.M. (Eds.), The Geologic Time Scale 2012. Elsevier, Amsterdam, pp. 793-853.

Ogg, J.G., Agterberg, F.P., Gradstein, F.M., 2004. The Cretaceous period. In: Gradstein, F., Ogg, J.G., Smith, A. (Eds.), A Geologic Time Scale. Cambridge University Press, Cambridge, pp. 344-383.

Ogg, J.G., Ogg, G., Gradstein, F.M., 2008. The Concise Geologic Time Scale. Cambridge University Press, Cambridge (177 pp.).

Ogg, J.G., Ogg, G., Gradstein, F.M., 2016. A Concise Geologic Time Scale. Elsevier (234 pp.).

Omarini, J., Moore, S., Tunik, M., Birgenheier, L., Brea, F., Milicich, R., Aguirre-Urreta, B. Lescano, M., Martinez, M., Giusiano, A., 2018. Geoquímica de la Formación Agrio (Cretácico Inferior) en el área de El Portón, Cuenca Neuquina: Primeros Resultados. $10^{\circ}$ Congreso de Exploración y Desarrollo de Hidrocarburos, Actas (10 pp.).

Pauly, S., Mutterlose, J., Alsen, P., 2012. Lower Cretaceous (upper Ryazanian-Hauterivian) chronostratigraphy of high latitudes (North-East Greenland). Cretaceous Research 34, 308-326.

Perch-Nielsen, K., 1985. Mesozoic calcareous nannofossils. In: Bolli, H.M., Saunders, J.B., Perch-Nielsen, K. (Eds.), Plankton Stratigraphy. vol. 1. Cambridge University Press, Cambridge, pp. 329-426.

Ramos, V.A., Folguera, A., 2005. Tectonic evolution of the Andes of Neuquén: constraints derived from the magmatic arc and foreland deformation. In: Veiga, G.D., Spalletti, L.A., Howell, J.A., Schwarz, E. (Eds.), The Neuquén Basin: A Case Study in Sequence Stratigraphy and Basin Dynamics. The Geological Society, Special Publication vol. 252, pp. 15-35.

Rawson, P.F., 1993. The influence of sea level changes on the migration and evolution of Lower Cretaceous (pre-Aptian) ammonites. In: House, M.R. (Ed.), The Ammonoidea: Environment, Ecology and Evolutionary Change. Systematics Association, Special Volume vol. 47, pp. 227-242.

Rawson, P.F., 2007. Global relationships of Argentine (Neuquén Basin) Early Cretaceous ammonite faunas. Geological Journal 42, 175-183.

Rawson, P.F. Aguirre-Urreta, B., 2012. Lower Cretaceous ammonites from the Neuquén Basin, Argentina: the Hauterivian genus Spitidiscus. Cretaceous Research 33, 97-105.

Reboulet, S., 1996. L'évolution des ammonites du Valanginien-Hauterivien inférieur du bassin vocontien et de la plate-forme provençal (S-E de la France): relations avec la stratigraphie séquentielle et implications biostratigraphiques. Documents des Laboratoires de Géologie Lyon 137, 1-371.

Reboulet, S., Atrops, F., 1999. Comments and proposals about the Valanginian-lower Hauterivian ammonite zonation of south-eastern France. Eclogae geologiae Helvetiae 92, 183-197.

Reboulet, S., Atrops, F., Ferry, S., Schaaf, A., 1992. Renouvellement des ammonites en fosse vocontienne à la limite Valanginien-Hauterivien. Géobios 25, 469-476.

Reboulet, S., Szives, O., Aguirre-Urreta, B., Barragán, R., Company, M., Idakieva, V., Ivanov, M., Kakabadze, M.V., Moreno-Bedmar, J.A., Sandoval, J., Baraboshkin, E.J., Çaglar, M.K., Fozy, I., González-Arreola, C., Kenjo, S., Lukeneder, A., Raisossadat, S.N., Rawson, P.F., Tavera, J.M., 2014. Report on the 5th International Meeting of the IUGS Lower Cretaceous Ammonite Working Group, the "KilianGroup" (Ankara, Turkey, 31st August 2013). Cretaceous Research 50, 126-137.

Reboulet, S., Szives, O., Aguirre-Urreta, B., Barragán, R., Company, M., Frau, C., Kakabadze M.V., Klein, J., Moreno-Bedmar, J.A., Lukeneder, A., Pictet, A., Ploch, I., Raisossadat, S.N., Vašǐček, Z., Baraboshkin, E.J., Mitta, V.V., 2018. Report on the 6th International Meeting of the IUGS Lower Cretaceous Ammonite Working Group, the "KilianGroup" (Vienna, Austria, 20th August 2017). Cretaceous Research 91, 100-110.

Rivera, T., Storey, M., Schmitz, M.D., Crowley, J.L., 2013. Age intercalibration of 40Ar/39Ar sanidine and chemically distinct $\mathrm{U} / \mathrm{Pb}$ zircon populations from the Alder Creek Rhyolite Quaternary geochronology standard. Chemical Geology 345, 87-98.

Ropolo, P., 1991. Crioceratites curnieri nov. sp. Une nouvelle espèce d'ammonite hétéromorphe préfigurant l'acquisition des coquilles tripartites de l'Hauterivien inférieur (Ammonoidea, Ancyloceratina). Mésogée 51, 65-73.

Rossi, G.C., 2001. Arenisca Avilé: facies, ambientes sedimentarios y estratigrafia de una regresión forzada del Hauteriviano inferior de la Cuenca Neuquina. Tesis Doctoral. Facultad de Ciencias Naturales y Museo, Universidad Nacional de La Plata (2 vols, $231+101$ pp., [unpublished]).

Roth, P., 1983. Jurassic and Lower Cretaceous Calcareous Nannofossils in the Western North Atlantic (Site 534): biostratigraphy, preservation, and some observations on biogeography and paleoceanography. Initial Reports of the Deep Sea Drilling Project 76, 587-621.
Rutledge, D., Bown, P.R., 1996. New names for old: taxonomic clarification of some Early Cretaceous nannofossils marker species. Journal of Nannoplankton Research 18, 53-59.

Sagasti, G., 2000. La sucesión rítmica de la Formación Agrio (Cretácico inferior) en el sur de la Provincia de Mendoza y su posible vinculación con ciclos de Milankovitch. Revista de la Asociación Argentina de Sedimentología 7, 1-22.

Sagasti, G., 2005. Hemipelagic record of orbitally-induced dilution cycles in Lower Cretaceous sediments of the Neuquén Basin. In: Veiga, G.D., Spalletti, L.A., Howell, J.A Schwarz, E. (Eds.), The Neuquén Basin: A Case Study in Sequence Stratigraphy and Basin Dynamics. The Geological Society, Special Publication vol. 252, pp. 231-250.

Schmitz, M.D., Davydov, V.I., 2012. Quantitative radiometric and biostratigraphic calibration of the global Pennsylvanian - Early Permian time scale. Bulletin Geological Society of America 124, 549-577.

Schmitz, M.D., Schoene, B., 2007. Derivation of isotope ratios, errors and error correlations for U-Pb geochronology using ${ }^{205} \mathrm{~Pb}^{235} \mathrm{U}-\left({ }^{233} \mathrm{U}\right)$-spiked isotope dilution thermal ionization mass spectrometric data. Geochemistry, Geophysics, Geosystems https://doi. org/10.1029/2006GC00149.

Schwarz, E., Spalletti, L.A., Veiga, G.D., Fanning, C.M., 2016. First U-Pb SHRIMP age for the Pilmatué Member (Agrio Formation) of the Neuquén Basin, Argentina: implications for the Hauterivian lower boundary. Cretaceous Research 58, 223-233.

Simon, J.I., Renne, P.R., Mundil, R., 2008. Implications of pre-eruptive magmatic histories of zircons for $\mathrm{U}-\mathrm{Pb}$ geochronology of silicic extrusions. Earth and Planetary Science Letters 266, 182-194.

Sissingh, W., 1977. Biostratigraphy of Cretaceous calcareous nannoplankton. Geologie en Mijnbouw 56, 37-65.

Sláma, J., Košler, J., Condon, D.J., Crowley, J.L., Gerdes, A., Hanchar, J.M., Horstwood, M.S.A. Morris, G.A., Nasdala, L., Norberg, N., Schaltegger, U., Schoene, B., Tubrett, M.N. Whitehouse, M.J., 2008. Plešovice zircon - a new natural reference material for U$\mathrm{Pb}$ and Hf isotopic microanalysis. Chemical Geology 249, 1-35.

Spalletti, L.A., Poire, D., Pirrie, D., Matheos, S., Doyle, P., 2001. Respuesta sedimentológica a cambiosen el nivel de base en una secuencia mixta clástica carbonática del Cretácico Inferior de la cuenca Neuquina, Argentina. Revista de la Sociedad Geológica de España $14,57-74$

Spalletti, L.A., Veiga, G.D., Schwarz, E., 2011. La Formación Agrio (Cretácico Temprano) en la Cuenca Neuquina. In: Leanza, H.A., Arregui, C., Carbone, O., Danieli, J.C., Vallés, J.M. (Eds.), Geología y recursos naturales de la provincia del Neuquén. Asociación Geológica Argentina, Buenos Aires, pp. 145-160.

Sprovieri, M., Coccioni, R., Lirer, F., Pelosi, N., Lozar, F., 2006. Orbital tuning of a lower Cretaceous composite record (Maiolica Formation, central Italy). Paleoceanography 21, PA4212. https://doi.org/10.1029/2005PA001224.

Taner, M.T., 2003. Attributes Revisited. Rock Solid Images, Inc., Houston, Texas URL: rocksolidimages.com/pdf/attrib_revisited.htm.

Thierstein, H., 1971. Tentative Lower Cretaceous calcareous nannoplankton zonation. Eclogae Geologicae Helvetiae 64, 459-488.

Thierstein, H., 1973. Lower Cretaceous calcareous nannoplankton biostratigraphy Abhandlungen der Geologischen Bundesanstalt 29, 1-52.

Thomson, D.J., 1982. Spectrum estimation and harmonicanalysis. Proceedings of the IEEE 70, 1055-1096.

Thomson, D.J., 1990. Quadratic-inverse spectrum estimates - applications to palaeoclimatology. Philosophical Transactions of the Royal Society A 332, 539-597.

van de Schootbrugge, B., Föllmi, K.B., Bulot, L.G., Burns, S.J., 2000. Paleoceanographic changes during the early Cretaceous (Valanginian-Hauterivian): evidence from oxygen and carbon stable isotopes. Earth and Planetary Science Letters 181, 15-31.

Veiga, G.D., Spalletti, L.A., Flint, S., 2002. Aeolian/fluvial interactions and high-resolution sequence stratigraphy of a non-marine lowstand wedge: the Avilé Member of the Agrio Formation (Lower Cretaceous), central Neuquén Basin, Argentina. Sedimentology 49, 1001-1019.

Vennari, V.V., Lescano, M., Naipauer, M., Aguirre-Urreta, B., Concheyro, A., Schalteggerb, U., Armstrong, R., Pimentel, M., Ramos, V.A., 2014. New constraints on the JurassicCretaceous boundary in the High Andes using high-precision U-Pb data. Gondwana Research 26, 374-385.

Vermeulen, J., 2004. Vers une nouvelle classification a’ fondement phylogénétique des ammonites hétéromorphes du Crétacé inférieur méditerranéen. Riviéra Scientifique $88,69-92$.

Voglino, S., 2017. Caracterización del Miembro Pilmatué de la Formación Agrio como reservorio no convencional de tipo shale. Trabajo final de licenciatura. Universidad Nacional de Rio Negro (198 pp., [unpublished]).

Waltham, D., 2015. Milankovitch period uncertainties and their impact on cyclostratigraphy. Journal of Sedimentary Research 85, 990-998. https://doi.org/ $10.2110 /$ jsr. 2015.66.

Watson, E.B., Wark, D.A., Thomas, J.B., 2006. Crystallization thermometers for zircon and rutile. Contributions to Mineralogy and Petrology 151, 413-433.

Weaver, C.E., 1931. Paleontology of the Jurassic and Cretaceous of West Central Argentina. Memoir of the University of Washington. vol. 1, pp. 1-469.

Westermann, G.E.G., 2000. Biochore classification and nomenclature in paleobiogeography: an attempt at order. Palaeogeography, Palaeoclimatology, Palaeoecology 158, 1-13. 